\title{
Transport upućen u Auschwitz iz Vinkovaca u kolovozu 1942. i sudbina srijemskih i bijeljinskih Židova za vrijeme Drugoga svjetskog rata
}

\author{
RAJKA BUĆIN \\ Hrvatski državni arhiv \\ Zagreb, Hrvatska \\ rbucin@arhiv.hr
}

U logor Auschwitz s područja Nezavisne Države Hrvatske bilo je u kolovozu 1942. upućeno pet transporta s oko 5000 Židova. Među njima je bio i transport iz Vinkovaca, koji je odande krenuo 19. kolovoza, a stigao 22. kolovoza 1942. godine. Bio je sastavljen od oko 1000 Židova s područja Srijema, tada u okviru velikih župa Vuka i Posavje (Ilok, Vukovar, Županja, Srijemska odnosno Hrvatska Mitrovica, Ruma, Šid, Stara Pazova), te ostatka židovske zajednice s područja kotara Bijeljina. Nakon što su od svibnja do kraja srpnja 1942. masovne deportacije Židova iz Srijema (Vinkovci, Zemun, Stara Pazova) u nekoliko navrata bile upućene u logore Jasenovac i Stara Gradiška, transportom iz kolovoza 1942. holokaust na području Srijema i Bijeljine uglavnom je okončan. Izuzeti su Židovi koji su bili u mješovitom braku, zdravstveni radnici i članovi njihovih obitelji te osobe koje su dobile poštedu na temelju pojedinačnih intervencija. Oni su obuhvaćeni deportacijama koje su uslijedile 1943. godine. Rad se osvrće i na prethodne deportacije te donosi nove spoznaje o osobama registriranima u knjigama mrtvih u Auschwitzu, deportiranima iz Vinkovaca i Zemuna u logore Jasenovac i Stara Gradiška, ali i druge spoznaje o povijesti holokausta na tom području Nezavisne Države Hrvatske. U istraživanju su korišteni izvorni dokumenti iz Hrvatskoga državnog arhiva, Arhiva Vojvodine, Arhiva Jugoslavije, Jevrejskoga istorijskog muzeja, Državnoga muzeja Auschwitz-Birkenau i drugih baštinskih ustanova.

Ključne riječi: Nezavisna Država Hrvatska; holokaust; Auschwitz; Jasenovac; sabirni logor u Vinkovcima; Srijem; Bijeljina

\section{Uvod}

Transporti Židova upućeni u Auschwitz u kolovozu 1942. s područja Nezavisne Države Hrvatske (NDH) uključuju i jedan iz Vinkovaca, koji je krenuo 19./20. kolovoza, a onamo stigao 22. kolovoza 1942. godine. Obuhvatio je oko 1000 Židova, pretežno s područja Srijema, ali i iz Bijeljine u obližnjoj Semberiji (sjeveroistočna Bosna), prethodno zatočenih u sabirnome logoru na igralištu „Cibalije” u Vinkovcima. Srijem je za vrijeme rata bio u sastavu 
$\mathrm{NDH},{ }^{1}$ a nakon rata podijeljen je prema ključu nacionalne pripadnosti stanovnika. ${ }^{2}$ Izvorni dokumenti iz toga razdoblja, ali i svjedočenja koja su nakon rata prikupljale komisije za utvrđivanje zločina okupatora i njihovih pomagača, kako su se službeno zvala ta tijela, nalaze se raspršeni između arhiva u Republici Hrvatskoj i Republici Srbiji, prije svega Hrvatskoga državnog arhiva i Arhiva Vojvodine, ali i drugih institucija. Vrijedni izvori nalaze se i u arhivu Državnoga muzeja Auschwitz-Birkenau, kamo je dio dospio tek 1990-ih, nakon raspada Sovjetskoga Saveza. Među njima važnu cjelinu čine izvodi iz matičnih knjiga umrlih, koji dopunjuju sliku o stradalima s ovih područja. ${ }^{3}$ Zbog raspršenosti i manje dostupnosti izvora u literaturi koja se bavi temama holokausta nailazi se na neujednačene tvrdnje kad je riječ o stradanju židovskoga stanovništva Srijema i spomenutome transportu. Uglavnom je ostao nezamijećen ili prešutno povezan s transportima iz drugih mjesta.

Prikazujući pregledno stradanje Židova na području Jugoslavije, Jaša Romano kaže da je u srpnju 1942. u vinkovačkom logoru, na igralištu kluba „Cibalia”, zatočeno 400 Židova s područja Vinkovaca (sic!) te drugih, iz Rume, Srijemske Mitrovice i raznih manjih mjesta iz okolice Iloka. Ne govori o ukupnom broju zatočenih. Kaže da su tri tjedna poslije odvedeni u Zagreb, odatle većinom u Auschwitz, a manja grupa u logor Jasenovac. Drugim riječima, Židove s područja Vinkovaca (uglavnom stradale u svibnju 1942. u Jasenovcu i Staroj Gradiški) povezuje s transportom iz kolovoza 1942., a neke druge koji su bili dijelom toga transporta izostavlja. Kad je riječ o hrvatskome dijelu Srijema, to se ponajprije odnosi na područje kotara i grada Vukovara te samoga Iloka, u kojima su bile nešto veće židovske zajednice, te na područje kotara i mjesta Županje. ${ }^{4}$ Narcisa Lengel-Krizman preuzima od Romana podatak o zatočenju „Židova iz Vinkovaca i nekih manjih mjesta u Srijemu" u logoru u Vinkovcima te govori o ukupnome broju od 400 osoba (sic!). Preuzima i podatak da su u kolovozu 1942. odvedeni u Jasenovac (manji dio) i Auschwitz (preostali). U kronologiji stradanja Židova s područja NDH

1 Za vrijeme austrougarske uprave te u okviru Kraljevine Srba, Hrvata i Slovenaca od 1918. do 1924. (do uspostave oblasti) Srijem je bio sastavnim dijelom Hrvatske i Slavonije. U razdoblju 1929. - 1939. podijeljen je između Savske i Dunavske banovine, a od 1939. spadao je u područje Banovine Hrvatske. Obuhvaćao je kotareve Vinkovci, Vukovar, Ilok (danas u Hrvatskoj), Irig, Šid, Ruma, Srijemski Karlovci, Srijemska Mitrovica, Stara Pazova i Zemun (danas u Srbiji). Taj ustroj kotareva ostao je nepromijenjen uspostavom NDH (ali se umjesto Srijemski Karlovci i Srijemska Mitrovica koriste nazivi Hrvatski Karlovci i Hrvatska Mitrovica). Usp. LANDIKUŠIĆ, Priručnik o političkoj i sudbenoj podjeli Nezavisne Države Hrvatske, 19. Kotarevi Zemun i Stara Pazova bili su do 10. listopada 1941. pod njemačkom upravom, a nakon toga i oni su predani vlastima NDH (KUMOVIĆ, Stradanje sremskih Jevreja, 35).

2 Najveće promjene nakon rata provedene su u pograničnim općinama Ilok, Vukovar i Šid, kojima su pripojena naselja s većinskim hrvatskim odnosno srpskim stanovništvom. Usp. ŠTAMBUK-ŠKALIĆ, „Hrvatska istočna granica”, 173-174.

3 PIPER, „Introduction”, 23.

4 Usp. ROMANO, Jevreji Jugoslavije, 111. Za vukovarske Židove kaže da su početkom studenoga 1941. odvedeni u Jasenovac, a prethodno su (još od kolovoza 1941.) bili zatočeni u ,jevrejskom hramu” (Isto). To se odnosi samo na manji dio vukovarskih Židova, većina je odvedena ovim transportom (op. a.). 
ne spominje Vinkovce kao polazišnu točku ijednoga transporta. ${ }^{5}$ Tomislav Žugić i Miodrag Milić u knjizi Jugosloveni u koncentracionom logoru Aušvic o transportu iz Srijema ne pišu, ali navode da je 22. kolovoza stigao „jedan transport Jevreja iz Jugoslavije“. U priloženome popisu zatočenika i žrtava logora Auschwitz nalaze se imena dijela Židova iz Vukovara, a ostali srijemski Židovi se ne spominju. ${ }^{6}$ Tomo Šalić, pišući o Židovima iz Vinkovaca i okolice, na temelju podataka iz poratnih obiteljskih listova, popisa Saveznoga zavoda za statistiku iz 1964. i drugih sličnih popisa, ali i pojedinačnih svjedočenja, točno utvrđuje da su oni uglavnom stradali u Jasenovcu i Staroj Gradiški. Za većinu ne navodi preciznije vrijeme odvođenja, a za neke nije siguran gdje su stradali. ${ }^{7}$ Mladenko Kumović u knjizi Stradanje sremskih Jevreja u holokaustu navodi podatke o stradanju Židova iz Srijema uglavnom prema onome što je prikupila Komisija za utvrđivanje zločina okupatora i njihovih pomagača Vojvodine, koristeći se više završnim elaboratom te komisije iz 1945. (koji je sumaran i mjestimično dosta površan), a manje pojedinačnim svjedočenjima na temelju kojih je elaborat nastao. Neka je izostavio, poput svjedočenja Abrahama Kišickog, a iz nekih se nije koristio pojedinostima koje su korištene u ovome radu. Zaključuje da je od Židova uhićenih u ljeto 1942., koji su zatočeni u sabirnom logoru u Vinkovcima, 20. kolovoza 1942. u Auschwitz upućena većina onih koji su bili iz Rume te pretpostavlja „verovatno [...] većina” iz Vukovara i Srijemske Mitrovice, a za Židove iz Iloka, Šida i Županje kaže da su tada deportirani u Jasenovac. ${ }^{8}$ Za dio iločkih Židova na jednome mjestu navodi i da su odvedeni na rad u Njemačku. ${ }^{9}$ Za Židove s područja Bijeljine tvrdi da su u ljeto 1942. odvedeni u Jasenovac preko Sremske Rače. ${ }^{10}$ Podatke Romana i/ili Kumovića, izravno ili neizravno, preuzimaju i drugi autori koji su pisali o povijesti Židova na području Vojvodine i Srijema, Pavle Šosberger i Ljiljana

5 LENGEL-KRIZMAN, „Logori za Židove u NDH”, 99; LENGEL-KRIZMAN, „Kronologija židovskog stradanja 1938.-1945.”, 254.

6 U popisu navode i da su iz Vinkovaca u Auschwitz odvedene Mira i Vera Kaf iz Vinkovaca (no njihov identitet nije jasan, a Tomo Šalić ih, baveći se Židovima iz Vinkovaca, ne spominje). Usp. ŽUGIĆ, MILIĆ, Jugosloveni u koncentracionom logoru Aušvic, 46-47, 173-348 (239).

ŠALIĆ, Židovi u Vinkovcima i okolici, 37-309, 440-445. Nije se koristio dokumentima iz fondova HR-HDA-252-RUR ŽO, HR-HDA-306-ZKRZ i HR-HDA-1549-ZIG, koji se ovdje poslije navode.

8 KUMOVIĆ, Stradanje sremskih Jevreja, 97.

9 Isto, 93.

10 Isto, 96. 
Dobrovšak. ${ }^{11} \mathrm{O}$ boravku bijeljinskih Židova u sabirnom logoru u Vinkovcima te njihovoj daljnjoj deportaciji u Auschwitz u literaturi nema podataka. ${ }^{12}$

U ovome radu nastoji se sagledati tijek prikupljanja Židova u Srijemu i na području Bijeljine u spomenutome razdoblju te rekonstruirati sastav transporta koji je u kolovozu 1942. krenuo iz Vinkovaca. Zbivanja u Srijemu, ali i Bijeljini, prikazuju se i ranije, kad su žrtve s toga područja najčešće stradavale u logorima NDH. Od svibnja do kolovoza 1942. holokaust je u Srijemu poprimio dramatične razmjere, najprije aktivnostima ustaških vlasti, a angažmanom upravnoga i policijskoga aparata Njemačkoga Reicha gotovo je potpuno završen.

\section{Općenito o tijeku holokausta i deportacijama u logor Auschwitz s područja Nezavisne Države Hrvatske}

Do ljeta 1942. odmazdama i deportacijama u ustaške logore obuhvaćen je velik dio židovskoga stanovništva NDH iz središnje i sjeverozapadne Hrvatske, dijela Slavonije te Bosne i Hercegovine. ${ }^{13} \mathrm{Na}$ temelju dogovora ustaških i njemačkih vlasti iz proljeća 1942., akcijom „izseljavanja Židova” trebalo je u

11 ŠOSBERGER, Jevreji u Vojvodini, 190; DOBROVŠAK, Židovi u Srijemu, 282, 296, 312. Pavle Šosberger kaže da su srijemski Židovi dopremljeni iz Tenje preko Loborgrada (čime njihov transport spaja s jednim od onih koji su krenuli iz Osijeka). Skupini pribraja i Židove iz Vinkovaca (sic!). Kao datum njihova dolaska u Auschwitz navodi 26. kolovoza 1942. (sic!). Ljiljana Dobrovšak ne ulazi u detaljniju analizu odvođenja Židova s područja Srijema. Na nekim mjestima preuzima podatke J. Romana (preko radova N. Lengel-Krizman), na drugima M. Kumovića. S obzirom na Šalićevu knjigu, Vinkovcima se nije posebno bavila. Uz poglavlja o Vukovaru i Iloku Dobrovšak donosi popise stradalih (oko 300 iz Vukovara te 377 iz Iloka).

12 PINTO, Zločini okupatora i njihovih pomagača, 412-414 (primjerak u: JIM, reg. br. 2960, k. 22.2a.2/6); TAUBER, Holokaust u Bosni i Hercegovini, 563.

13 Logorski sustav NDH sastojao se od niza logora, za koje se koriste nazivi sabirni i radni logori (za potonje se koristi i izraz koncentracijski). Među njima su važnu ulogu imale dvije veće skupine logora, poznate po masovnom stradanju zatočenika. Od početka ljeta do kolovoza 1941. djelovala je skupina logora Gospić - Velebit (Jadovno) - otok Pag (Slana i Metajna). Nakon talijanske reokupacije toga dijela NDH u kolovozu 1941. oni se prestaju koristiti. Žene iz logora u Gospiću i na Pagu preko Jastrebarskog i Kruščice uglavnom dospijevaju u logor Loborgrad, neke i u Đakovo, a muškarci u Jasenovac. U blizini Jasenovca osnovani su logori Krapje i Bročice (najranije 23. kolovoza 1941.), udaljeni nekoliko kilometara od mjesta, poznati kao Jasenovac I i II. U studenome 1941., kad se oni ukidaju, osniva se logor Jasenovac III (Ciglana). Na području mjesta Jasenovac krajem 1941. odnosno početkom 1942. nastao je i radni logor „Kožara”, poznat kao Jasenovac IV. U okviru Kaznionice u Staroj Gradiški (koja je udaljena 30-ak km od Jasenovca) krajem 1941. osniva se logor poznat kao Jasenovac V. Od veljače 1942. Kaznionica se i formalno proglašava „sabirnim i radnim logorom”. U njega se nakon toga u većoj mjeri dovode zatočenice. Usp. LENGEL-KRIZMAN, „Logori za Židove u NDH”, 94; KEVO, „Počeci logora Jasenovac”, 473-480; KEVO, „Počeci jasenovačkog logora i pojmovna (terminološka) problematika”, 574, 578, 580-582. Lengel-Krizman upozorava i na privremena sabirališta kao mjesta kratkotrajnoga djelovanja, bez straže i logorske uprave, odakle su Židovi slani u sabirne i radne logore (LENGEL-KRIZMAN, „Logori za Židove u NDH", 100). 
ljeto 1942. u Auschwitz biti upućeno nekoliko transporta da se holokaust na području NDH što prije i efikasnije privede kraju. Najprije je bilo planirano da akcija započne krajem srpnja, a onda je pomaknuta na kolovoz. ${ }^{14}$ Iseljavanje ili preseljavanje bilo je uobičajen izraz u praksi vlasti Njemačkoga Reicha. Korišten je za masovne deportacije Židova u logore pod njemačkom upravom, mahom na području okupirane Poljske, gdje su stradali većinom odmah po dolasku. ${ }^{15}$ Akcija o kojoj je ovdje riječ organizirana je nakon što je u proljeće 1942. pokrenut rad dvaju velikih krematorija na lokaciji Auschwitz-Birkenau (Auschwitz II). Uz postojeći krematorij u matičnom logoru Auschwitz I trebali su pridonijeti bržoj provedbi odluke o konačnom rješenju židovskoga pitanja, donesene 20. siječnja 1942. na konferenciji u Wannseeu. ${ }^{16} \mathrm{Na}$ području NDH iz deportacija su u kolovozu 1942. izostavljani zdravstveni radnici i članovi njihovih obitelji, osobe u mješovitim brakovima (slično je bilo uređeno i njemačkim propisima) te osobe za koje su postojale pojedinačne intervencije. ${ }^{17}$

Za provedbu akcije „iseljavanja” sa strane Njemačkoga Reicha bio je delegiran Hauptsturmführer Franz Abromeit iz židovskoga referata Odjela IV-B Glavne uprave za sigurnost Reicha (Reichssicherheitshauptamt - RSHA) iz Berlina, koji je s tim zadatkom došao u Zagreb u ljeto 1942 . godine. ${ }^{18} \mathrm{Sa}$ strane NDH za organizaciju željezničkih transporta bio je nadležan Vilko Kühnel, nadstojnik Židovskoga odsjeka Ravnateljstva za javni red i sigurnost

14 HR-HDA-252-RUR ŽO, 5125/1942, 5186/1942. Usp. GOLDSTEIN, Holokaust u Zagrebu, 119.

15 PIPER, „The Role of the Auschwitz Camp”, 20-21; GOLDSTEIN, Holokaust u Zagrebu, $424,426$.

16 O konferenciji u Wannseeu: GOLDSTEIN, Holokaust u Zagrebu, 11-12. Deportacije u Auschwitz odvijale su se sustavno nakon izgradnje spomenutih objekata, ponajprije sa zapadnoeuropskih i obližnjih srednjoeuropskih područja (npr. današnje Slovačke). Samo iz okupirane Francuske u razdoblju 1942. - 1944. u Auschwitz je upućeno 77 transporta, za koje su utvrđeni podatci o polascima i broju deportiranih i ubijenih po dolasku (riječ je o 77000 deportiranih osoba), a postoji i više njih bez točno utvrđenih podataka. Prvi je krenuo iz Drancyja 27. ožujka 1942. godine. Vidi: KLARSFELD, Le calendrier de la persécution des Juifs de France. Prvi transport u organizaciji Glavne uprave za sigurnost Reicha iz Berlina u Auschwitz je stigao tek 4. srpnja 1942., a s područja bivše Jugoslavije 10. kolovoza 1942. iz Celja. Vidi: CZECH, „A Calendar of the Most Important Events”, 156.

17 Postojale su i odgovarajuće odluke i naredbe donesene 1942. u NDH u vezi s osobama u mješovitim brakovima. No te odluke nisu uvijek niti dosljedno provođene. Vidi: GOLDSTEIN, Holokaust u Zagrebu, 378-384, 426, 538-539. Usp. PIPER, „The Role of the Auschwitz Camp”, 21-22. Pored toga od lipnja 1941. u Banjoj Luci je uspostavljen Zavod za suzbijanje endemijskoga sifilisa u Bosni, zbog čega su iz deportacija mogli biti izuzeti liječnici i članovi njihovih najužih obitelji. Vidi: GOLDSTEIN, „Solidarnost i pomoć Židovima u Hrvatskoj”, 212.

18 Franz Abromeit (Tilsit, 8. kolovoza 1907. - ?). Rođen je u istočnoj Pruskoj. Nije imao veću formalnu naobrazbu. Radio je kao trgovac, potom bio član SD Leitabschnitta u Königsbergu. Poslije je radio u Odjelu IV-B Glavne uprave za sigurnost Reicha u Berlinu, koji je bio nadležan za rješavanje „Židovskoga pitanja”. U ljeto 1942. dodijeljen je Njemačkom poslanstvu u Zagrebu radi deportacije Židova s područja NDH. Potom je raspoređen na druge slične poslove. Vidi: HR-HDA-1521, Arhiv Hansa Helma, dosje Franza Abromeita. Pobjegao je iz Njemačke na kraju Drugoga svjetskog rata (pretpostavlja se u Egipat), a 1964. proglašen je mrtvim. Vidi: „Franz Abromeit”. 
(RAVSIGUR) NDH, na temelju odluke Zapovjedništva Ustaške nadzorne službe (UNS) od 27. srpnja 1942. godine. Tada je akcija prema prvotnoj zamisli trebala i započeti, ali je iz organizacijskih razloga početak pomaknut za otprilike dva tjedna. ${ }^{19}$ Organizacija transporta bila je u nadležnosti vlasti $\mathrm{NDH}$ do granice, a dalje su njima upravljale njemačke vlasti sa svojim redarstvenim tijelima. ${ }^{20} \mathrm{U}$ akciju je uključen i Ivan Tolj, tadašnji predstojnik Kotarske oblasti Vinkovci te upravitelj Gradskoga redarstva i Ispostave Župske redarstvene oblasti u Vinkovcima. ${ }^{21}$ Bio je zadužen za uhićenja Židova i njihovo prikupljanje u sabirnim logorima na području istočne Slavonije i Srijema. To su mu dopuštale ovlasti dodijeljene već 18. srpnja 1942., kad je Eugen Kvaternik, u svojstvu zapovjednika UNS-a, ${ }^{22}$ „otvorenom zapovijedi” priopćio župskim upravnim i redarstvenim tijelima da Tolj može poduzeti „sve mjere potrebne za rješavanje židovskog pitanja” na području Velike župe Vuka, ali i obližnjih velikih župa (Baranja, Livac-Zapolje i Posavje). ${ }^{23}$ Nakon što su transporti odgođeni za sredinu kolovoza središnjim državnim tijelima i župskim redarstvenim oblastima ponovno je priopćeno da je Ivan Tolj voditelj „redarstvenih mjera oko koncentriranja i smještanja izseljenika u privremena sabirališta”, ${ }^{24}$ među koje je spadalo i naselje (geto) Tenja u Osijeku. ${ }^{25}$ Židovski odsjek RAVSIGUR-a utvrdio je prije početka akcije da će transporti krenuti 13. i 24. kolovoza iz Zagreba te 16., 20. i 27. kolovoza iz Osijeka, uz mogućnost dodatnoga transporta 30. kolovoza 1942. „prema naknadnoj obaviesti”. ${ }^{26}$ No

19 Usp. HR-HDA-1549-ZIG, I-18, 656 i HR-HDA-223-MUP NDH, Ravsigur, ŽO, 5026/1942.

20 HR-HDA-1561-SDS RSUP SRH, Dosje br. 301999 (Hans Helm). Usp. GOLDSTEIN, Holokaust u Zagrebu, 431.

${ }^{21}$ Ivan Tolj (Veljaci, BiH, 18. ožujka 1901. - Vinkovci, srpanj 1945.). U travnju 1941. imenovan je za predstojnika Kotarske oblasti Vinkovci i upravitelja Gradskoga redarstva, a potom i Ispostave Župske redarstvene oblasti u Vinkovcima. Prethodno je bio na mjestu predstojnika Župske redarstvene oblasti u Sarajevu. Krajem 1944. pobjegao je iz Vinkovaca, ali je 1945. uhvaćen i osuđen na smrt. Vidi: HR-HDA-223-MUP NDH, Personalni dosje, br. 463; HR-HDA-252-RUR ŽO, 5186/1942; HR-HDA-1549-ZIG, I-18, 656; HR-HDA-1561-SDS RSUP SRH, 013.0.42.

22 Eugen Dido Kvaternik (Zagreb, 29. ožujka 1910. - Rio Cuarto, Argentina, 10. ožujka 1962.), od svibnja 1941. bio je ravnatelj Ravnateljstva za javni red i sigurnost, koje je djelovalo u okviru MUP-a NDH, a od kolovoza 1941. zapovjednik Ustaške nadzorne službe kao posebnoga ustaškog redarstva. Obnašao je obje funkcije do listopada 1942., kad je smijenjen zbog pretjerane samovolje i terora koji je provodio (to je imalo loš utjecaj na niz stvari, pa i na percepciju režima u javnosti). Od veljače 1943. Kvaternik je boravio u Slovačkoj, a nakon rata otišao je u Argentinu. Ondje je 1962. stradao u prometnoj nesreći. Vidi: STUPARIĆ, Tko je tko u NDH, 223-225; KOVAČIĆ, Redarstveno-obavještajni sustav Nezavisne Države Hrvatske, 71-80, 213.

${ }^{23}$ HR-HDA-1549-ZIG, 71, 267. O aktivnostima Ivana Tolja u okviru ove akcije u Osijeku usp. ŽIVAKOVIĆ-KERŽE, Stradanja i pamćenja, 134, 138-139, 141.

24 Okružnicama od 3. i 11. kolovoza 1942. godine. Vidi: HR-HDA-252-RUR ŽO, 5186/1942; HR-HDA-1549-ZIG, I-70, 2629. Usp. HR-HDA-1549-ZIG, I-18, 656.

25 ŽIVAKOVIĆ-KERŽE, Stradanja i pamćenja, 128-129, 135-137.

26 HR-HDA-252-RUR ŽO, 5026/1942. Iz njemačkih izvora vidi se da je s područja NDH 7. kolovoza 1942. bilo planirano čak sedam teretnih vlakova, ali se od toga odustalo. GOLDSTEIN, Holokaust u Zagrebu, 429. 
već dan nakon što je krenuo prvi transport iz Zagreba odlučeno je da će polazna stanica jednoga transporta biti u Vinkovcima, u kojemu su tijekom druge polovine srpnja prikupljeni Židovi s područja Srijema. ${ }^{27}$ Sjedište Velike župe Vuka i pripadajuće župske redarstvene oblasti, a od kolovoza 1942. i sjedište Višega redarstvenog povjereništva, bilo je u Vukovaru, a u Vinkovcima je bilo sjedište Ispostave Župske redarstvene oblasti. ${ }^{28}$ Bez obzira na to Vinkovci su za represivni aparat NDH, ali i Njemačkoga Reicha, imali veliku važnost jer su bili željezničko čvorište kroz koje je prolazilo nekoliko lokalnih i međunarodna pruga iz smjera Beograda i Zemuna prema Zagrebu. ${ }^{29}$ Velika župa Vuka obuhvaćala je najveći dio Srijema (kotarevi Hrvatska Mitrovica, Hrvatski Karlovci, Ilok, Irig, Ruma, Stara Pazova, Šid, Vinkovci, Vukovar i Zemun, tj. sve osim Županje) te je Ivan Tolj ondje, očito imajući na umu tamošnje Židove te blizinu tako važne željezničke pruge, organizirao rad privremenoga sabirnog logora na igralištu „Cibalije”. Županja je do 5. srpnja 1944. bila na području Velike župe Posavje, a tada je i ona priključena Velikoj župi Vuka. ${ }^{30}$ Na području Velike župe Posavje, kojoj su uz Županju pripadali kotarevi Bijeljina, Brčko, Brod na Savi, Derventa i Gradačac, najveći dio deportacija zbio se već prije, ponajviše u smjeru Jasenovca i Stare Gradiške. Slično vrijedi i za Veliku župu Livac-Zapolje, koja je također tijekom ove akcije formalno bila u nadležnosti Ivana Tolja. ${ }^{31}$ Iznimke su bile Županja i Bijeljina. Židovi kotara Županja prije su pojedinačno bili obuhvaćeni internacijama, a njihovo masovnije „čišćenje” može se povezati tek uz logor u Vinkovcima. Tolj je akcijom obuhvatio i područje Bijeljine, gdje je od ljeta do listopada 1941. obnašao položaj predstojnika kotarske oblasti. ${ }^{32}$ Tijekom 1941. i 1942. tamošnji su Židovi bili u nekoliko navrata upućeni u logore na području NDH. To je, sudeći prema sačuvanim popisima, uključilo u većem broju muško židovsko stanovništvo Bijeljine, u manjoj mjeri žene. ${ }^{33}$ Posljednja deportacija s područja Bijeljine zbila se 1. kolovoza 1942., kad je skupina Židova upućena u logor u Vinkovcima, a poslije s ostalima u Auschwitz, kako se vidi iz nastavka ovoga rada.

27 HR-HDA-252-RUR ŽO, 5122/1942.

28 KOVAČIĆ, Redarstveno-obavještajni sustav Nezavisne Države Hrvatske, 114, 297-298.

29 Usp. RAKIČIĆ FRIEDRICH, Razvoj željezničke mreže u hrvatskom Podunavlju, 53-54, 60, 63-64, 72, 73, 87, 134, 135, 151.

30 O ustroju velikih župa Vuka i Posavje te promjenama koje su nastupale na njihovu području vidi: BUĆIN, „Prilog poznavanju institucija”, 221, 223.

31 HR-HDA-306-ZKRZ, Guz, 2235/19-45 i 2235/26-45. Tako je primjerice najveći dio Židova iz Nove Gradiške odveden u Jasenovac i Staru Gradišku 26./27. prosinca 1941., a iz Slavonskog Broda 22. siječnja 1942. (žene poslije u Đakovo). Slično vrijedi i za Požegu.

32 HR-HDA-223-MUP NDH, Personalni dosje, br. 463.

33 U popisima Jasenovca s kraja 1941. i početka 1942. bilo je registrirano 30-ak muških osoba iz Bijeljine u dobi od 17 do 64 godine. Vidi: MILETIĆ, Koncentracioni logor Jasenovac, knj. 1, 117-148 („Spisak logoraša Koncentracionog logora Jasenovac”). Bijeljinske žene bile su evidentirane i kao logorašice Loborgrada i Đakova, ali u manjem broju (usp. bilj. 157). Židovi iz Bijeljine nisu registrirani na popisu logora Jadovno Đ. Zatezala (ZATEZALO, Jadovno, knj. $1,423-426)$. 
Nakon transporta koji je otišao u Auschwitz iz Zagreba 13. kolovoza, drugi transport s oko 1000 Židova krenuo je 15./16. kolovoza iz Osijeka, kako je prije dogovoreno. Promjenom plana od 14. kolovoza 1942. odlučeno je da će polazišna točka za transporte u Auschwitz biti i Vinkovci, uz Loborgrad i Zagreb. ${ }^{34}$ Treći transport krenuo je iz Vinkovaca u noći 19./20., a 20. kolovoza napustio je područje NDH. To je vremenski odgovaralo terminu koji je prethodno bio određen za jedan od osječkih transporta. ${ }^{35}$ Preostali Židovi koncentrirani u Osijeku prebačeni su 18. i 22. kolovoza u Loborgrad (dio je „iskrcan” u Jasenovcu) te su odatle tijekom sljedećih dana u dva transporta upućeni u Auschwitz zajedno s dijelom loborgradskih zatočenica i dvije manje skupine Židova dovedenih iz Sarajeva. ${ }^{36}$ Posljednji transport od 30. kolovoza otkazan je s konstatacijom da se „kompozicija posebnog vlaka [...] za otpremu Židova u Njemačku” ukida te da je „time završeno [...] iseljavanje istih sa područja Nezavisne Države Hrvatske u Njemačku". ${ }^{37}$ Hans Helm, kao njemački redarstveni izaslanik u $\mathrm{NDH},{ }^{38}$ izvijestio je u listopadu veleposlanika Njemačkoga Reicha Siegfrieda Kaschea ${ }^{39}$ da je od 13. do 27. kolovoza „u Njemačku" odvedeno 5000 Židova iz NDH. ${ }^{40}$ Slične je podatke objavio i šef statističkoga ureda SS-a Richard Korherr. Prema njima, u logore na području okupirane Poljske tijekom 1942. godine deportirano je 4927 Židova s područja NDH. ${ }^{41}$ Dio Židova, poglavito oni uhićeni tijekom svibnja, lipnja i srpnja 1942. u raznim mjestima NDH, deportiran je u Jasenovac i Staru Gradišku. To je slučaj s pojedinim skupinama iz Zagreba, Sarajeva, Banje Luke i drugih mjesta s područja Bosne i Hercegovine, ${ }^{42}$ ali i Židovima iz Vinkovaca i

34 HR-HDA-252-RUR ŽO, 5122/1942.

35 HR-HDA-252-RUR ŽO, 5189/1942, 5200/1942, 5240/1942. Usp. ŽIVAKOVIĆ-KERŽE, Stradanja i pamćenja, 140-141.

36 Iz potonjega od ta dva osječka transporta upućena u Loborgrad otkvačena su dva vagona sa starijim osobama iz Osijeka (oko 120 osoba) u Jasenovcu, a nekoliko dana prije, prema različitim procjenama, skupina od 100 do 300 zanatlija iz Osijeka također je prebačena u Jasenovac. Vidi: ŽIVAKOVIĆ-KERŽE, Stradanja i pamćenja, 138-139, 140. Usp. ROMANO, Jevreji Jugoslavije, 132; DIZDAR, „Logori na području sjeverozapadne Hrvatske”, 95.

37 HR-HDA-252-RUR ŽO, 5274/1942.

38 Hans Helm (München, 30. lipnja 1909. - Beograd, 1947.) bio je imenovan za redarstvenoga izaslanika (policijskoga atašea) u NDH u proljeće 1942. godine. Zarobljen je na kraju rata i osuđen na smrt u Beogradu. Posljednji iskaz dao je pred tijelima istrage sredinom veljače 1947. godine. Vidi: HR-HDA-1561-SDS RSUP SRH, Dosje br. 301999. Usp. STUPARIĆ, Tko je tko u NDH, 155 (navedeno je da je pogubljen krajem 1946.).

39 Siegfried Kasche (Strausberg pokraj Berlina, 18. lipnja 1903. - Zagreb, 7. lipnja 1947.) bio je veleposlanik i opunomoćeni ministar Njemačkoga Reicha u NDH. Član Nacionalsocijalističke njemačke radničke stranke (NSDAP) od 1926. godine. Nakon rata uhvaćen u bijegu, osuđen i pogubljen u Zagrebu (STUPARIĆ, Tko je tko u NDH, 183).

40 PERŠEN, Ustaški logori, 104.

${ }^{41}$ „Der Korherr-Bericht“ (Die Endlösung der Europäischen Judenfrage). U domaćoj literaturi korišten je podatak o 4972 Židova, preuzet iz strane literature (Usp. npr. GOLDSTEIN, Holokaust u Zagrebu, 434).

42 HR-HDA-252-RUR ŽO, 3715/1942, 3827/1942, 4304/1942, 4540/1942, 4612/1942, 4623/1942, 4708/1942, 4780/1942, 4781/1942, 4782/1942, 4813/1942, 4875/1942, 4981/1942, 5031/1942, 5193/1942, 5362/1942 itd. Usp. MILETIĆ, Koncentracioni logor Jasenovac, knj. 1, 297-298, 341, 404, 411-413, 415-418, 421-422. 
Zemuna, o kojima će biti više riječi u daljnjem tekstu. Uz Jasenovac se u ljeto 1942. veže i sudbina žena iz sabirnoga logora u Đakovu. ${ }^{43}$

Na području NDH holokaust ni tim akcijama ipak nije proveden do kraja, u prvom redu stoga što je dio židovskoga stanovništva bio izuzet od deportacija po raznim osnovama, skrivao se ili je bio u bijegu. O tome ponovno svjedoči izvješće koje je Helm u listopadu 1942. uputio Kascheu. ${ }^{44}$ Deportacije su se stoga odvijale i kasnije, no u znatno manjoj mjeri. One su obuhvatile dotad pojedinim mjerama zaštićene ili sakrivene Židove iz Zagreba, ali i drugih mjesta, u kojima ih je ostao znatno manji broj. Bile su ponajviše upućene u Auschwitz, a u pojedinim slučajevima i u Jasenovac i Staru Gradišku. Njima je obuhvaćen i znatan dio Židova iz mješovitih brakova, koji su pošteđeni godinu dana prije. ${ }^{45}$ Najveći dio tih deportacija zbio se u svibnju 1943., kad su prema Auschwitzu krenula dva posljednja velika kontingenta (s oko 2000 osoba). ${ }^{46}$ Smatrajući da je židovsko pitanje na području NDH tijekom 1943. riješeno, Kasche je krajem te godine izvijestio svoje nadređene u Berlinu da su „Židovi i slobodni zidari već odstranjeni u Hrvatskoj” ${ }^{47}$ Bez obzira na to Helm je i sljedeće godine javio Kascheu da još ima iznimaka po raznim osnovama. Tijekom 1944. radi se uglavnom o pojedinačnim deportacijama i dovršetku mjera vezanih uz "čišćenje” priobalnih krajeva. ${ }^{48}$ Osobito se to odnosi na Židove koji su uhvaćeni kao prebjezi na teritorij pod kontrolom Narodnooslobodilačke vojske i partizanskih odreda Jugoslavije ili su se skrivali na neki drugi način. Takav je slučaj bio s dijelom logoraša nekadašnjega talijanskog logora za Židove na Rabu, uhvaćenih 1944. u Lici. Dio logoraša s Raba, njih oko 1300, pridružio se nakon pada Italije Narodnooslobodilačkoj vojsci i partizanskim odredima Jugoslavije, a oko 1800 prebačeno je postupno na teritorij Like, Banije i Korduna i bilo je pod skrbi Zemaljskoga antifašističkog vijeća narodnog oslobođenja Hrvatske. Oni uhvaćeni u Lici deportirani su u Auschwitz u ožujku 1944. zajedno sa skupinom od 180 do 200 bivših zatočenika logora koji su ostali na Rabu. ${ }^{49}$

43 VASILJEVIĆ, Sabirni logor Đakovo, 73-76. O tome govori više svjedočenja. Za dio žena postoji i nagađanje da su još iz Đakova odvedene na rad u Njemačku (prema iskazu jasenovačkoga zatočenika Egona Bergera). Usp. Isto, 74-75. Drugi izvori i službeni dokumenti to ne potvrđuju. Postoje i iskazi Mihajla Solaka i Luke Đakovića (neposrednih svjedoka) o njihovu stradanju u Jasenovcu (HR-HDA-421-JTH SRH, Odjeljenje bezbjednosti, 4.3.3., B 124/1951).

44 PERŠEN, Ustaški logori, 23-26.

45 To se vidi na više mjesta u ovome radu. Slično zapaža i I. Goldstein za 1943., komentirajući da nije našao posebne upute u vezi s takvim postupanjem. GOLDSTEIN, Holokaust $u$ Zagrebu, 466.

46 Isto, 434, 473.

47 Isto, 476.

48 KRIZMAN, Ustaše i Treći Reich, sv. 1, 337-338.

49 LENGEL-KRIZMAN, „Koncentracioni logori talijanskog okupatora”, 281; GOLDSTEIN, Holokaust u Zagrebu, 531, 576. 
Kronologija i tijek uhićenja Židova na području Velike župe Vuka te u kotarevima Županja i Bijeljina od svibnja do kolovoza 1942. s osvrtom na ranija zbivanja: uhićenja, internacije, bjegovi

U svibnju 1942., više od tri mjeseca prije početka akcije deportiranja u Auschwitz, masovna uhićenja Židova na području Velike župe Vuka započeo je Ivan Tolj. On je u travnju bio imenovan predstojnikom Kotarske oblasti i upraviteljem Gradskoga redarstva, a uskoro i upraviteljem Ispostave Župske redarstvene oblasti u Vinkovcima, no u grad je stigao tek 1. svibnja 1942. godine..$^{50}$ Ubrzo po dolasku započeo je s uhićenjima Židova na području grada i kotara Vinkovci, a deportacije je usmjerio prema logorima Jasenovac i Stara Gradiška. Na području Vinkovaca velika skupina Židova uhićena je već 3. i 4. svibnja. ${ }^{51}$ Uhićenici su bili smješteni u privremeno sabiralište u zgradi Hrvatskoga sokola, koja se nalazila u vinkovačkoj četvrti Lenije. O tome svjedoči Zlatko Marton, tada 11-godišnjak, uhićen 4. svibnja 1942. zajedno $\mathrm{s}$ roditeljima i bratom, ${ }^{52}$ ali i Vlado Zabludovski, star 7 godina, koji kaže da su ih kamionima prebacili u „sokolski dom”. ${ }^{33}$ Prema sjećanju Vere Schwarz, ona i majka bile su u svibnju 1942. zatočene „u nekoj velikoj sali”, što bi također trebalo odgovarati opisu sokolskoga doma. ${ }^{54}$ Pored vinkovačkih Židova, tim su uhićenjima obuhvaćeni i Židovi iz okolice, s područja vinkovačkoga kotara, među ostalima iz Ivankova, Retkovaca i drugih naselja, o čemu su svjedočili Ladislav Lion i Drago Ausländer iz Ivankova. ${ }^{55}$ Kao upravitelj Ispostave Župske redarstvene oblasti u Vinkovcima, Tolj je poslije izvijestio Ministarstvo unutarnjih poslova (MUP) da je u skladu s naredbom MUP-a „u gradu Vinkovcima [bilo] internirano najedanput 380 Židova i židovki”. ${ }^{56}$

${ }^{50}$ HR-HDA-223-MUP NDH, Personalni dosje, br. 463. Usp. ŠALIĆ, Židovi u Vinkovcima i okolici, 425 .

51 Šalić spominje te datume uz nekoliko imena iz Vinkovaca (ŠALIĆ, Židovi u Vinkovcima i okolici, 191, 297), ali postoje i drugi izvori koji to dokumentiraju, a nije ih koristio. Usp. HRHDA-252-RUR ŽO, 4927/1942.

52 Zlatko Marton (Vinkovci, 1. rujna 1930. - ?), sin Aleksandra Martona i Lili r. Oblath. Vidi: ŠALIĆ, Židovi u Vinkovcima i okolici, 191. O sokolskome domu: Isto, 434. Zgrada postoji i danas.

53 Vlado Zabludovski (Vinkovci, 27. svibnja 1935. - ?), sin Izraela Zabludovskog i Eve r. Pink, doseljenika iz Poljske. Nakon rata, kao 12-godišnjak bez roditelja, preselio se u Izrael. Isto, 280-281.

${ }^{54}$ Vera Schwarz, poslije Zelda Jakobson (Vinkovci, 1929. - Izrael, ?), kći Aleksandra Schwarza i Roze r. Hoffman. Poslije je odvedena u Osijek te se uz pomoć rođaka spasila bijegom u Hrvatsko primorje, potom u Castelvecchio (Verona) i Rim. Otac je 1941. odveden u Jasenovac i ondje je stradao. Za majku je čula da je iz Vinkovaca odvedena u Đakovo te odatle u Auschwitz (sic!). Roza Schwarz odvedena je prema odluci UNS-a od 21. svibnja 1942. u Jasenovac (op. a.). Usp. Isto, 252-253; HR-HDA-252-RUR ŽO, 4927/1942.

55 HR-HDA-306-ZKRZ, Guz, 2235/26-45 (Lion); ŠALIĆ, Židovi u Vinkovcima i okolici, 297 (Ausländer). Drago Ausländer iz Ivankova svjedoči da ih je 3. svibnja 1942. susjed upozorio na to da je u Vinkovcima vidio odvođenje Židova „bez obzira na spol i dob”. Zapamtio je točan datum jer je sljedećega dana bio njegov rođendan.

56 HR-HDA-1549-ZIG, II-31, 1761. 
Pojedinci su uspjeli isposlovati dozvole za odlazak iz Vinkovaca, kao što je bio slučaj s obitelji Bresslauer (poslije su ubijeni ili poginuli) i Sinberger (pušteni su na intervenciju ustaše Došena, koji je stanovao kod njih). ${ }^{57} \mathrm{Za} 366$ odraslih od 4. do 7. svibnja izrađeni su kartoni s tipiziranim tekstom i prijedlogom UNS-u da budu poslani na prisilni boravak u logor na pet godina jer „su pomagali englesku promičbu lažnih viesti” te „mrze sile osovine, a time i samu N.D.H. [itd.]” ${ }^{58}$ Odlukom UNS-a od 21. svibnja 1942. upućeni su u Jasenovac odnosno Staru Gradišku. Prema priloženome popisu, skupina je tada imala 358 osoba. ${ }^{59} \mathrm{O}$ njihovu dolasku svjedoči Erwin Miller iz Vinkovaca, koji je ondje bio interniran od studenoga 1941. godine. Kaže da su u svibnju 1942. u Staru Gradišku, gdje se tada nalazio, stigli „ostaci vinkovačkih Židova”. Tim su transportom stigle njegova majka Ružica i sestra Felicitas Miller te znanice Zlata Schwarz i Rifka Herzog. ${ }^{60}$ Njihova se imena nalaze i na spomenutome popisu od 21. svibnja, kao i imena Mavre Ausländera i Leopolda Liona iz Ivankova, čiji su sinovi posvjedočili o uhićenjima početkom svibnja. ${ }^{61}$ Pored masovne deportacije u svibnju 1942. bilo je i nekoliko prethodnih internacija i deportacija s vinkovačkoga područja u razne logore na području HDH. Skupina mlađih Židova komunista odvedena je 1941. u Lepoglavu, odakle su neki ujesen te godine prebačeni u Jasenovac. Među njima je bio i Leo Zilzer, za kojega se obično misli da je ubijen u Lepoglavi. ${ }^{62}$ Neki su stradali u ljeto 1941. u Jadovnom ili na Pagu (Slana). ${ }^{63}$ U Jasenovac je početkom studenoga 1941. dovedena skupina od više desetaka vinkovačkih Židova, pretežno mlađih muškaraca, među kojima je bio i Erwin Miller (tada u dobi od nepunih 18 godina). Većina je stradala u kratkome razdoblju po dolasku, a tek su pojedinci ostali dulje na životu. ${ }^{64}$ Tijekom svibnja 1942. dogodio se i pokušaj spašavanja

57 ŠALIĆ, Židovi u Vinkovcima i okolici, 67, 257.

58 HR-HDA-306-ZKRZ, Guz, 2235/26-45, Okrug Slavonski Brod, kartoteka Vinkovci.

59 HR-HDA-252-RUR ŽO, 4927/1942.

60 MILLER, Izabran za umiranje, 44, 73. O Milleru vidi i: ŠALIĆ, Židovi u Vinkovcima $i$ okolici, 206-207 te MOTL, MIHOVILOVIĆ, Zaboravljeni, 539-540. Erwin Miller (Vinkovci, 27. siječnja 1922. - Maabarot, Izrael, 28. lipnja 1991.) bio je interniran u Jasenovcu u studenom 1941., a spasio se u proboju iz Kožare 1945. godine. U sjećanjima navodi imena osoba u Jasenovcu i Staroj Gradiški koje je susretao, čijem je dovođenju u logor, pa i smrti, nazočio, posebice Vinkovčana. Usp. MILLER, Izabran za umiranje, 10, 46-47, 49, 51, 72, 99, 101, 103-104, $106,109,116-117,118-119,121-122,123$.

${ }_{61}$ HR-HDA-252-RUR ŽO, 4927/1942. Usp. bilj. 55.

62 ŠALIĆ, Židovi u Vinkovcima i okolici, 283, 432; ŠVOB, Židovi u Hrvatskoj, knj. 2, 583. Miller je svjedok njegova pribivanja u Jasenovcu te kaže da je u Lepoglavi bio zatočen prije početka rata. Usp. MILLER, Izabran za umiranje, 10.

63 Na popisu Đ. Zatezala nalaze se: Miroslav (Lavoslav) Aldan, 36 g., Leo Epštajn (Ernest), 20 g., Gustav Velheln (M.), 38 g. (vjerojatno Gustav Wilhelm, sin Moritza, op. a.). Vidi: ZATEZALO, Jadovno, knj. 1, 443-444.

64 MILLER, Izabran za umiranje, 101, 105. Miller govori o skupini od „osamdesetak zaplašenih Židova" dovedenih u Jasenovac početkom studenoga 1941., a poslije napominje da je uglavnom riječ o mladićima. Šalić govori o skupini od 64 vinkovačka mladića koji su 7. studenog 1941. odvedeni u Jasenovac. Vidi: ŠALIĆ, Židovi u Vinkovcima i okolici, 433. Podatak o 64 mladića donosi i Kumović (ali nejasno citira Koljanina, koji je preuzeo Šalićeve podatke), a od Kumovića ih preuzima Dobrovšak, govoreći o miješanoj grupi od 64 mladića iz Vinkovaca i 
dvojice mladića koji su vjerojatno bili dio te skupine: Harryja Deitelbauma (r. 1927.) i Josipa Rotha (r. 1926.). Oni su se našli na popisu transporta za Tursku koji je Marija Bauer iz Vinkovaca (tada nastanjena u Turskoj) u svibnju 1942. nastojala organizirati za 86 djece i adolescenata, većinom iz Zagreba, ali nije uspjela. ${ }^{65} \mathrm{Na}$ istome popisu našla se i Lea Kaff (r. 1928.) iz Vinkovaca, no i ona je, pretpostavlja se, odvedena u Jasenovac odnosno Staru Gradišku. ${ }^{66} \mathrm{Pi}$ tanje Židova s područja grada i kotara Vinkovci akcijom iz svibnja 1942. bilo je uglavnom dovršeno. U toj skupini deportiranih u Jasenovac i Staru Gradišku bilo je znatno manje muškaraca nego žena, a među muškarcima je bio razmjerno najveći udio starijih od 50 godina. ${ }^{67}$ Kao i u drugim mjestima, bile su pošteđene osobe u mješovitim brakovima, relativno malobrojne na tom području, ali i dio njih interniran je i stradao u Jasenovcu i Staroj Gradiški, a Židovi koji su prešli na kršćanstvo bez obzira na to većinom su također stradali. ${ }^{68}$ Posljednja uhićenja u Vinkovcima obuhvatila su 18. kolovoza 1942. šest starijih Židovki, koje su otpremljene u Jasenovac. ${ }^{69}$ Podatci o židovskim izbjeglicama prispjelima prije 1941. s područja pod kontrolom Njemačkoga Reicha u Vinkovce su manjkavi. ${ }^{70}$

Tijekom uhićenja u svibnju 1942. Židovska bogoštovna općina u Vinkovcima ishodila je dozvolu da vinkovačka djeca mlađa od 13 godina mogu biti poslana u Osijek. Vjerojatno su s njima u Osijek upućena i djeca đakovačkih logorašica, koja su bila udomljena kod pojedinih obitelji. Ukupno ih je na tome području bilo 57. Većina je bila smještena u Vinkovcima, a dvoje u

Vukovara (sic!). Usp. KOLJANIN, „Jevreji žrtve rata 1941.-1945.”, 186; KUMOVIĆ, Stradanje sremskih Jevreja, 90-91; DOBROVŠAK, Židovi u Srijemu, 282.

65 LEBL, „'Kindertransport' iz Nezavisne Države Hrvatske”, 190-194. Ne nalaze se na popisu upućenih u Jasenovac i Staru Gradišku od 21. svibnja 1942., kao ni njihovi očevi Hugo Deitelbaum i Geza Roth, no svi su stradali 1942. godine (usp. HR-HDA-252-RUR ŽO, 4927/1942 i ŠALIĆ, Židovi u Vinkovcima i okolici, 71-72, 235).

66 LEBL, „Kindertransport' iz Nezavisne Države Hrvatske”, 193. Lea Kaff ne nalazi se na popisu za Jasenovac i Staru Gradišku od 21. svibnja 1942., a ni njezin otac Filip Kaff (majka Jelisaveta/Beška r. Kadelbaum bila je na popisu od 21. svibnja). Vidi: HR-HDA-252-RUR ŽO, 4927/1942. Svi se smatraju stradalima u Jasenovcu 1942. godine (usp. ŠALIĆ, Židovi u Vinkovcima i okolici, 160).

67 Usp. HR-HDA-252-RUR ŽO, 4927/1942. Krajem svibnja posebno su ondje odvedeni Herman i Matilda Marton (ŠALIĆ, Židovi u Vinkovcima i okolici, 188, 433).

68 ŠALIĆ, Židovi u Vinkovcima i okolici, 446-447. Od lipnja 1941. do siječnja 1942. krštene su 42 osobe (svi su stradali). Za neke osobe iz mješovitih brakova sudbina nije poznata (npr. Savo Samuel Pollak iz Orolika, Jovanka Deutsch, Boris Skljar i Margareta Šuprina iz Vinkovaca, koji su bili u mješovitim brakovima te su i sami promijenili vjeroispovijest). Među preživjelima je bila Irena Goldstein r. Adler, rođena 1903., koja se preudala za vrijeme rata te je preživjela pod imenom Irena Građanski. Nelly Kellert, koja je prihvatila vjeru supruga Lea, Židova, vratila se 1941. na katoličku vjeru zajedno sa kćerima. Preživjele su sve tri, a suprug je ubijen u Jasenovcu (Isto, 78, 112, 163-164, 258, 293, 306, 439).

${ }^{69}$ Isto, 164.

70 Šalić navodi nekoliko imena prema podatcima iz obiteljskih listova sastavljenih nakon rata. Vidi: Isto, 441. 
Starim Mikanovcima. ${ }^{71}$ Sudbine su im bile različite, ovisno o okolnostima. Po svemu sudeći, većinom su uključeni u deportacije iz kolovoza 1942. upućene iz Osijeka u Auschwitz. ${ }^{72}$ Postoje svjedočenja o pojedinačnim spašavanjima i bjegovima za nekoliko vinkovačke djece. ${ }^{73}$ Dvanaestogodišnju Veru Schwarz preuzeli su i skrivali rođaci iz Osijeka, a poslije se spasila prelaskom k ujaku u Sušak te bijegom u Italiju. ${ }^{74}$ Zlatko Marton i njegov brat Miroslav bili su također smješteni u Osijeku, kod jedne židovske obitelji. Poslije su ih majčine sestre prokrijumčarile u Sombor, na područje koje je za vrijeme Drugoga svjetskog rata pripojeno Mađarskoj. Ondje su ostali do 1944., kad su obuhvaćeni masovnim deportacijama mađarskih Židova upućenima u Auschwitz. Nakon „nekoliko selekcija deportirani su [...] zajedno s tetkama na prisilni rad u Austriju, a u ožujku 1945. prebačeni u logor Theresienstadt”. ${ }^{75}$ Nada Goldberger, tada u dobi od oko 7 godina, prisjeća se da su dobivši dozvolu za odlazak u Osijek na kolodvor odvezeni fijakerima (kao godinu zbivanja navodi 1941., sic!) te da su po dolasku u Osijek bili raspoređeni po židovskim obiteljima. Nakon odvođenja osječkih Židova u kolovozu 1942. skrivali su ju susjedi. Po nju je došla tetka iz Zagreba, koja ju je predala na čuvanje u samostan Nazaret u Šestinama, gdje je ostala sakrivena do kraja rata. ${ }^{76}$ Slično je posvjedočio i Vlado Zabludovski, tada star nepunih 7 godina. On je najprije bio skriven kod obitelji Vajs u Osijeku. Nakon toga, uz pomoć stanodavaca svojih roditelja, obitelji Radičević iz Vinkovaca, te izvjesnoga Zovka iz Zagreba, povjerenika Ureda za podržavljeni imetak nadležnog za upravljanje tvornicom Borovic u kojoj je radio njegov otac, bio je sakriven u dječjem domu kojim su upravljale opatice u Osijeku. ${ }^{77}$

I dok je Tolj provodio uhićenja na području grada i kotara Vinkovci, odlukom UNS-a iz svibnja 1942. uhićena je i skupina od 63 Židova s područja Stare Pazove. Oni su 6. svibnja 1942. odvedeni u Jasenovac odnosno Staru Gradišku bez zadržavanja u Vinkovcima. ${ }^{78}$ No prema podatcima Abrahama Kišickog, preživjeloga zatočenika sabirnoga logora na igralištu „Cibalije”, neki Židovi iz kotara Stara Pazova dovedeni su u taj logor (u srpnju ili najkasnije početkom kolovoza 1942., op. a.). Teško je utvrditi je li podatak točan jer drugi dokumenti o tome nisu poznati. No ako jest, radilo bi se o posljednjim ostatcima

71 Prvotno je bilo odobreno samo 37 za Vinkovce, ostalih 20 trebalo je biti smješteno u Osijeku, ali je plan promijenjen te su sva djeca upućena u Vinkovce. O tome je posvjedočio Samuel Leo Grinvald iz Vinkovaca, koji je u akciji osobno sudjelovao. Vidi: VASILJEVIĆ, Sabirni logor Đakovo, 32-33, 224-227. Kod Živaković-Kerže tih 20 prikazano je kao da su ostali u Osijeku. Usp. ŽIVAKOVIĆ-KERŽE, Stradanja i pamćenja, 120, 122.

72 Usp. ŽIVAKOVIĆ-KERŽE, Stradanja i pamćenja, 138.

73 Na popisima koje objavljuje Lebl za djecu s područja NDH koju se tijekom 1942. pokušalo spasiti (djelomično i uspjelo početkom 1943. slanjem u Palestinu) ne navode se djeca toga uzrasta iz Vinkovaca (LEBL, „'Kindertransport' iz Nezavisne Države Hrvatske”, 192-193).

74 ŠALIĆ, Židovi u Vinkovcima i okolici, 253.

75 Isto, 191, odnosno 190-192.

76 Isto, 105.

77 Isto, 280-281.

78 NJEGOVAN, Zločini okupatora i njihovih pomagača, 298. 
ove zajednice, možda 15-ak ili nešto više osoba. ${ }^{79}$ Tijekom lipnja i srpnja 1942. u Jasenovac i Staru Gradišku deportirani su u više navrata i Židovi s područja grada Zemuna. Za dvije od tih deportacija, koje su obuhvatile 232 osobe, sačuvani su prateći popisi UNS-a od 8. lipnja i 1. srpnja 1942., dostavljeni Židovskome odsjeku RAVSIGUR-a u Zagrebu. I ta dva transporta upućena su izravno u Jasenovac i Staru Gradišku. ${ }^{80}$ Postoji i podatak da su 28./29. srpnja 1942. „iz postelja podignuti svi [svi preostali?, op. a.] zemunski Jevreji te da je kompozicija sastavljena od 15 vagona [...] sa oko 450 zemunskih Jevreja” krenula u smjeru Vinkovaca, ali nije ondje iskrcana. ${ }^{81}$ Nastavila je put prema Jasenovcu, kamo su stigli 30. srpnja, a žene su s djecom odatle odvedene u Staru Gradišku. Poslije u Zemunu više gotovo i nije bilo Židova. Nekolicina je odvedena krajem kolovoza 1942. također u Jasenovac odnosno Staru Gradišku, a oni koji su izuzeti od tih deportacija, njih desetero, stradali su 1943. u Auschwitzu. ${ }^{82}$

Druge masovnije deportacije Židova koje bi iz Srijema išle izravno u smjeru Jasenovca u ostalim mjestima toga područja od svibnja do srpnja 1942. nije moguće pratiti. Preostale deportacije bile su uglavnom upućene u Auschwitz preko sabirnoga logora u Vinkovcima u okviru šire akcije „iseljavanja” koja je provedena u kolovozu 1942. godine. Aktivnosti oko uhićenja u okviru te masovne akcije odvijale su se sukcesivno. Za neke su gradove i kotareve poznati i točni datumi uhićenja i odvođenja u Vinkovce, a za neke je naznačen samo mjesec. Do koje je mjere akcija provedena sustavno pokazuje izvješće Kotarske oblasti Hrvatski Karlovci, na čijem je području početkom rata bilo iznimno malo Židova. Izvješće je sastavljeno 28. srpnja 1942. na zahtjev MUP-a NDH. Kotarska oblast javila je tada MUP-u da ne može udovoljiti nalogu „da se svi Židovi kotara uhite i sprovedu u Vinkovce” jer su ih još u ožujku 1942. uhitili „organi njemačke vojne sile” (radilo se o Židovima iz Inđije i Beške). ${ }^{83}$ Upućeni su tada u logor u Zemunu. ${ }^{84}$ Židovski odsjek Ravnateljstva ustaškoga redar-

79 Nisu evidentirani ni u Auschwitzu. Vidi: Svjedočenje Abrahama Kišickog (faksimil), u: BABIĆ, Zločini ustaša, 337-342.

80 HR-HDA-252-RUR ŽO, 4328/1942, 4538/1942. Time je 8. lipnja 1942. onamo deportirano 132 Židova, a 1. srpnja 1942. još 100 Židova iz Zemuna.

81 NJEGOVAN, Zločini okupatora i njihovih pomagača, 298-299. Istovremeno se spominje i da je u tim vagonima bilo smješteno po 40 osoba, pa bi po tome ukupan zbroj bio 600 Židova.

82 Podatak o uhićenju 450 Židova 28./29. srpnja 1942. preuzima i Fogel (FOGEL, Jevrejska zajednica u Zemunu, 106-113), a od njega KUMOVIĆ, Stradanje sremskih Jevreja, 93. Kumović donosi i faksimile dopisnica nekolicine zemunskih Židova koji su bili uključeni u rad u Kožari i pojedinim radnim grupama Jasenovca. Vidi: KUMOVIĆ, Stradanje sremskih Jevreja, 102-105. I u Zemunu je bilo stranih izbjeglica, pa se smatra da je i dio njih obuhvaćen akcijom s kraja srpnja 1942. godine. Usp. DOBROVŠAK, Židovi u Srijemu, 310, 312.

83 HR-HDA-252-RUR ŽO, 4931/1942.

84 HR-HDA-252-RUR ŽO, 4200/1942. U Zemunu je bio logor pod upravom njemačkih okupacijskih vlasti u Srbiji. Najprije je bio logor za Židove (Judenlager Semlin), ali i Rome, uglavnom s područja okupirane Srbije, koji su ubijani na razne načine (u „gasnom” kamionu, na stratištima na području Beograda) ili odvođeni u druge logore. Od travnja 1942. imao je i ulogu prolaznoga („prihvatnog”) logora (Anhaltelager Semlin) za područje bivše Kraljevine Jugoslavije na kojem su bile prisutne njemačke vlasti i vojne snage. Najveći dio zatočenika 
stva (kasnije RAVSIGUR-a) i UNS, ne znajući za to, tražili su nekoliko puta od ožujka do kolovoza 1942. od redarstvenih vlasti u Inđiji, odnosno Župske redarstvene oblasti u Hrvatskim Karlovcima, da te Židove predaju UNS-u radi internacije u logorima Jasenovac i Đakovo odnosno Stara Gradiška. ${ }^{85}$

Većina Židova iz tadašnje Hrvatske (Srijemske) Mitrovice uhićena je u srpnju 1942., kako to konstatira pokrajinska komisija za utvrđivanje ratnih zločina u svojem završnom elaboratu iz prosinca 1945. godine. ${ }^{86}$ Bili su najprije smješteni u sabirnom logoru u Mitrovici, potom su odvedeni u Vinkovce, odakle su u kolovozu „verovatno”, kako kaže Komisija, deportirani u Auschwitz. Pokrajinska komisija prikupila je i svjedočenja iz kojih je za nekolicinu pojedinaca vidljivo da su uhićeni godinu dana prije (Pero Morgenstern i sinovi, Sandor i Imre Fleischman, Adolf Rosenberg). Neki od njih još su između kolovoza i listopada 1941. dospjeli u logor Krapje pokraj Jasenovca. ${ }^{87} \mathrm{U}$ prvoj polovini 1942. odvedeno je u Jasenovac još nekoliko pojedinaca, o kojima je ujesen 1945. svjedočila Mirjam Vajs (Weiss). U proljeće 1942. „sa transportom Roma” iz Mitrovice u Jasenovac je odveden njezin djed Sigfrid Levi te s njim Ignac Frankfurter i Žiga Hubert. ${ }^{88}$ Točan broj odvedenih u Vinkovce u srpnju 1942. pokrajinska komisija u završnom elaboratu ne navodi. ${ }^{99}$ Prema jednom izvješću napisanom na njemačkom jeziku, vjerojatno za potrebe poratnih tijela progona, oni su bili zatočeni u Mitrovici te su u lipnju 1942. (sic!) odvedeni u Vinkovce, a odatle deportirani s velikom grupom Židova u Auschwitz. ${ }^{90}$ Mirjam Vajs svjedoči o 46 osoba koje je poznavala iz toga transporta za Vinkovce (pored četvero članova njezine obitelji) te izrijekom kaže da su iz Vinkovaca „odvedeni u nepoznatom pravcu za Poljsku”. Jedan dio, njih ukupno

(taoci, antifašisti, pripadnici Narodnooslobodilačke vojske i partizanskih odreda Jugoslavije i sl.) upućivan je na rad i internaciju u logore na području pod kontrolom Njemačkoga Reicha te u Norvešku (KOLJANIN, Nemački logor na beogradskom Sajmištu, 56-65, 170 i d.).

85 Usp. HR-HDA-252-RUR ŽO, 2538/1942, 4200/1942 i 4931/1942. Radilo se o obiteljima Pisker, Stiller, Morgenstein i Ferdinandu Becku iz Inđije te obitelji Kotona iz Beške.

86 NJEGOVAN, Zločini okupatora i njihovih pomagača, 300.

87 Petar (Pero) Morgernstern bio je prvi uhićeni mitrovički Židov. Uhićen je već 24. travnja 1941. te upućen u logor Koprivnica. Stradao je u logoru Jadovno. Iz Jasenovca se u proboju uspio spasiti Josip Morgenstern (doveden 1941. iz Gospića), a logor je preživio i Samuilo (Šimun) Morgenstern (prema jednim podatcima bio je u Jasenovcu, prema drugima u zarobljeništvu). Vidi: NJEGOVAN, Zločini okupatora i njihovih pomagača, 300; RS 002-183PKRZ, inv. br. 4858; HR-HDA-421-JTH SRH, 4.3.3., B 124/1951, Popis interniranih Židova u Jasenovcu, 24. 10. 1941. i Popis zatočenika Jasenovca, 1-1454; ZATEZALO, Jadovno, knj. 1, 718; DIZDAR, Logor Danica u Koprivnici, knj. 1, 489; MOTL, MIHOVILOVIĆ, Zaboravljeni, 245-246.

88 RS 002-183-PKRZ, inv. br. 4858.

89 NJEGOVAN, Zločini okupatora i njihovih pomagača, 300.

90 JIM, inv. br. 2667, K-24-3-4-/1, Flüchtlingslager „Sremska Mitrovica” (1941.-1942.), 13. 3. 1946. „In Juni 1942 ging eine grosse Gruppe Juden über Vinkovce, angeblich nach Polen ab. Ihr Schicksal ist unbekannt. Die letzte Gruppe wurde nach Zagreb transportiert und von dort aus in plombierten Waggonen nach Auschwitz." To je očita pogreška jer su svi transporti u Auschwitz krenuli u kolovozu, a prikupljanje srijemskih Židova u Vinkovcima može se pratiti tek od sredine srpnja 1942. godine. Faksimil u: KUMOVIĆ, Stradanje sremskih Jevreja, 82. 
13, vraćen je iz Vinkovaca u Mitrovicu jer su živjeli u mješovitim brakovima ili imali zdravstvene radnike u obitelji, ali su i oni obuhvaćeni deportacijama u svibnju 1943. godine. ${ }^{11}$ Njezina obitelj bila je također ponovno uhićena 1943. te tada preko Zagreba upućena u Auschwitz. Prema svjedočenju Mirjam Vajs, od mitrovičkih Židova, kojih je prije rata bilo 84, do jeseni 1945. znalo se za 18 preživjelih. Među njima su bile i ona i njezina majka Josefina Vajs r. Levi kao preživjele zatočenice Auschwitza. Na kraju je stradalo, prema njezinu iskazu, 62 Židova iz Mitrovice. Neki su stradali na području Srijema, u logoru Banjica, izbjeglištvu ili partizanima, ali većinom u Auschwitzu. Prema elaboratu pokrajinske komisije, koji je dovršen u prosincu 1945., prije rata u Mitrovici je bilo Židova „svega 70 duša” te su gotovo potpuno „uništeni”. Podatci Mirjam Vajs u tom su pogledu potpuniji jer ona navodi poimenično i stradale i preživjele pojedince. Uz zapisnik svjedočenja priložila je popis sa 84 imena, od čega je prema njezinu iskazu 37 osoba u ljeto 1942. deportirano „za Poljsku”.92

Na području grada i kotara Ruma početkom rata bilo je oko 250 domicilnih Židova te između 200 i 300 izbjeglica s područja pod kontrolom Njemačkoga Reicha, prispjelih u Kraljevinu Jugoslaviju prije travnja 1941. godine. Kao mjesta njihova stradavanja navode se najčešće logori NDH. ${ }^{93} \mathrm{U}$ srpnju 1941. upućeni su u većem broju preko sabirnoga logora u Hrvatskoj (Srijemskoj) Mitrovici u logor u Gospiću, a potom u Jasenovac i Loborgrad..$^{94}$ U Jasenovcu je ujesen 1941., prema evidencijama kojima je raspolagala Židovska bogoštovna općina u Zagrebu, bilo registrirano 6 muškaraca iz te skupine, a s njima i jedan domicilni Židov, Aladar Richtman (Richtmann). ${ }^{95}$ Dio izbjeglica iz Rume dospio je iz Gospića u Loborgrad. ${ }^{96}$ U proljeće 1942. bilo je u Loborgradu 16 žena i djece iz te skupine, a u kolovozu su odatle deportirani u Auschwitz. ${ }^{97}$ Postoji i popis interniraca „s područja Ž.B.O. u Rumi”, nastao 19. studenog 1941., koji također navodi strane izbjeglice iz Rume u Jasenovcu i Loborgradu..$^{98}$ Da vjerojatno ipak nisu svi stradali na području NDH pokazuju knjige umrlih iz logora Auschwitz, u kojima se nalazi nekolicina osoba

91 Johana Subić i Anica Mihajlović, tri člana obitelji Frajnd, četiri člana obitelji Ferstner te četiri člana obitelji Vajs. Vidi: RS 002-183-PKRZ, inv. br. 4858.

92 RS 002-183-PKRZ, inv. br. 4858. I u svjedočenju navodi imena stradalih (spomenuti popis nije više u predmetu).

93 Prema Elaboratu o domaćim Nemcima za srez rumski, 300 stranih izbjeglica smještenih u Rumi odvedeno je 1941. u Staru Gradišku i Loborgrad (Arhiv Vojvodine). Na temelju toga elaborata Romano govori o 250 domicilnih Židova i 300 stranih izbjeglica. Te podatke preuzimaju i drugi, primjerice Kumović. Dobrovšak govori o 200 stranih izbjeglica u Rumi. Goldstein ukazuje na 153 izbjeglice u Rumi o kojima se do lipnja 1941. skrbila zagrebačka židovska općina. Usp. ROMANO, Jevreji Jugoslavije, 93-94; GOLDSTEIN, Holokaust u Zagrebu, 244; KUMOVIĆ, Stradanje sremskih Jevreja, 62; DOBROVŠAK, Židovi u Srijemu, 282.

94 O „odiseji” stranih izbjeglica iz Rume vidi: GRUENFELDER, Sustigla ih Šoa, 148, 182.

95 HR-HDA-421-JTH SRH, 4.3.3., B 124/1951, Popis zatočenika Jasenovca (1-1454). Usp. HR-HDA-1076-PONOVA, Prijave (Ruma), Richtman, Aladar.

${ }_{96}$ Na popisu Đ. Zatezala nalaze se samo tri osobe iz Rume te nisu u pitanju Židovi. Vidi: ZATEZALO, Jadovno, knj. 1, 704-705.

97 Usp. HR-HDA-1514-UPK NDH, Popis zatočenica u logoru Loborgrad (1-1032).

98 JIM, reg. br. 6481, k. 60-8-1/15. 
iz Rume za koje je, prema navedenim podatcima o mjestu rođenja i boravištu roditelja, prilično izvjesno da su također stranci. ${ }^{99}$ Pojedinci su i među njima bili pošteđeni deportacija kao pripadnici mješovitih brakova. Jedna od takvih bila je obitelj Lustig iz Beča. Supružnici Jakob i Tereza, inače katolkinja po rođenju, u to vrijeme trudna, te njihovo dvoje djece pokušali su ipak napustiti Rumu još u rujnu 1941. godine. Nakon zatočenja u Vukovaru, koje je uslijedilo nakon što su uhvaćeni, bili su prebačeni u Jasenovac i Staru Gradišku. Ondje je Jakob ubijen, a Tereza i sin Robert preživjeli su rat. U Gradiški joj je od gladi umrlo dvoje djece, što uključuje i novorođenče koje se rodilo po majčinu dolasku u logor. ${ }^{100}$ Max Scholl, rođen u Njemačkoj, također izbjeglica u Rumi, uspio je izbjeći deportacije 1941. i 1942. godine. Moguće je da je i on bio u mješovitom braku. U Auschwitz je upućen u svibnju 1943., a umro je u prosincu iste godine. ${ }^{101}$

Domicilni Židovi iz Rume zatočeni su također u srpnju 1941. u sabirnom logoru u Hrvatskoj (Srijemskoj) Mitrovici, ali su pušteni i vraćeni kućama nakon plaćanja otkupnine. ${ }^{102}$ Neki od njih bili su kasnije internirani u logorima na području NDH, kao što pokazuje slučaj spomenutoga Aladara Richtmana. Među njima je i 9 osoba koje su tijekom lipnja 1942. upućene u neki od ustaških logora. ${ }^{103}$ Jedan od Židova interniranih u logoru Jasenovac bio je iz rumske obitelji Unterberger (preživio je rat). Ostali članovi te obitelji većinom su deportirani u Auschwitz (njih 7), ali i u neke „lokalne” logore, ili su stradali na području Srijema. Iz Auschwitza se vratio samo Adam Unterberger, koji je o tome svjedočio pred pokrajinskom komisijom za ratne zločine. Prema njegovu iskazu, 17. srpnja 1942. mjesto je blokirano te su Židovi imali na raspolaganju nekoliko minuta prije napuštanja kuća da pokupe nužne stvari, novac i nakit. Odvedeni su u skladišta Uljarice, a odatle prebačeni u logor u Vinkovcima. ${ }^{104}$ Zagrebački Deutsche Zeitung objavio je 5. kolovoza 1942. vijest da je zadnjih 156 rumskih Židova iz toga, kako kažu, pretežno njemačkoga grada odvedeno u židovski logor u Vinkovcima („Judenlager Vinkovci”) u okviru akcije preseljenja Židova („Judenaussiedlung”). ${ }^{105} \mathrm{U}$ fragmentarno sačuvanom arhivu Gradskoga poglavarstva Rume za to razdoblje nalazi se nekoliko dokumenata iz kojih se vidi da je manji broj Židova izbjegao deportacije skrivanjem i bijegom u partizane, poput Julijane Justus s djetetom, te da su i među njima

\footnotetext{
99 Oni nisu registrirani u Ponovi (Erwin Almoslino, Alexander Krausz, Rudolf Hacker, Ludwig Löwenstein, Irma Löwy i Willi Schönfeld).

100 RS 002-183-PKRZ, inv. br. 4843 (svjedočenje Tereze Lustig). Tereza Lustig r. Szid rođena je oko 1905. u Beču. Usp. JIM, ŽOZ, Reg. br. 2505, k. 24-7-2/8 (popis zatočenika Stare Gradiške, 10. 3. 1944.).

101 DM AB, Sterbebuch, 34039/1943. Max Scholl, kemijski tehničar, rođen 15. 11. 1884. u Pirmasensu, Njemačka, umro 1. 12. 1943. u Auschwitzu. Roditelji: Julius Scholl i Johanna r. Bodenheimer, supruga: Liesel Scholl r. Gims.

102 ROMANO, Jevreji Jugoslavije, 93-94.

103 HR-HDA-252-RUR ŽO, 4013/1942.

104 ERAK, „Rumski Jevreji”, bilj. 87; RS 002-183-PKRZ, inv. br. 4855; NJEGOVAN, Zločini okupatora i njihovih pomagača, 301.

105 BETHKE, (K)eine gemeinsame Sprache?, 334.
} 
bili pošteđeni pojedinci iz mješovitih brakova. ${ }^{106}$ Takav je bio slučaj pravoslavne Židovke Borislave Malenković, liječnice udane za Svetolika Malenkovića, Srbina, također liječnika, mobiliziranog 1942. u domobransku radnu postrojbu na području Spačve (poslije promaknutog u čin nadsatnika). ${ }^{107} \mathrm{Ne}-$ kolicina rumskih Židova u prethodnom je razdoblju prešla na katoličanstvo uz pomoć lokalnoga župnika Ivana Lajtnera (Ervin i Johana Schiller, Magda Steiner, Sidonija Steiner, Valerija Dragičević, možda i neki drugi), ali njihova daljnja sudbina nije poznata. ${ }^{108}$ Prema postojećim podatcima, od navedenih je stradala samo Sidonija Steiner (Štajner), i to u Jasenovcu. ${ }^{109} \mathrm{Za} \mathrm{Lea} \mathrm{Kaufmana,}$ koji je bio interniran u Vinkovcima sa suprugom i trogodišnjim sinom, upućena je molba iz Rume, koju je podnio tamošnji ustaški dužnosnik Pavelić, da bude pušten jer se „slagao sa Hrvatima i Niemcima” iz grada te je bio cijenjeni stručnjak, ali to nije uvaženo te se i on nalazi među žrtvama u knjigama mrtvih Auschwitza. ${ }^{110}$

Židovi s vukovarskoga područja prevezeni su kamionima u Vinkovce 26. srpnja 1942. godine. Uhićenja su ondje provedena prema popisima kojima su raspolagali „domaće ustaše i ustaše iz Borova”. Poimence se spominju redarstvenici Filakovac i Pletikosić, a u akciju se osobno uključio i Ivan Tolj, koji je tim poslom došao u Vukovar. ${ }^{111}$ Još početkom 1942. Župska redarstvena oblast u Vukovaru sastavila je evidenciju Židova za grad Vukovar, prema kojoj je u gradu bilo „107 rasnih židova, 113 članova pokrštenih židova i 10 polužidova”, ukupno 230 osoba, od čega desetero djece iz mješovitih obitelji. ${ }^{112}$ U izvještaju pokrajinske komisije za utvrđivanje ratnih zločina u Vojvodini akcija od 26. srpnja 1942. opisana je kao "glavno odvođenje” Židova iz Vukovara, kojim je obuhvaćeno 177 osoba. Bile su obuhvaćene čitave obitelji i osobe različite dobi, ali ponajviše žene, djeca i starci, koji nisu bili uključeni

106 ERAK, „Rumski Jevreji”. Erak je 2014. upozorio na fragmente pismohrane Gradskoga poglavarstva Rume u Istorijskom arhivu Srema u Srijemskoj Mitrovici.

107 Prema iskazu njegova sina Miloša Malenkovića. Vidi: ERAK, „Rumski Jevreji”.

${ }_{108}$ Nisu na popisima stradalih (usp. sljedeću bilješku), ali se ne nalaze ni među sudionicima Narodnooslobodilačke borbe J. Romana ni na popisima izbjeglica s područja NDH u Švicarskoj i Italiji. Usp. ROMANO, Jevreji Jugoslavije, 307-511; SR-AJ-50, Predsedništvo Vlade, 50-4-9; PIZZUTI, „Dalla Jugoslavia occupata”.

109 ŽIVKOVIĆ, Imenik stradalih osoba AP Vojvodine, 394 (Štajner Sidonija). Sidonija Štajner ne navodi se među žrtvama Jasenovca s područja Rume u popisu Statističkoga zavoda Jugoslavije iz 1964. godine. Vidi: Jasenovac: žrtve rata, 770-771. Iz toga je popisa žrtava rata 1941. - 1945. napravljen ekscerpt za Jasenovac (objavljen u nekoliko primjeraka 1992.), koji je 1998. tiskan u obliku reprinta. Čitav popis (ne samo za Jasenovac) dostupan je (uz dopune) na mrežnim stranicama Muzeja genocida u Beogradu (što može biti praktičnije i za pretraživanje). Vidi: „Popis žrtava rata 1941-1945.: Vojvodina” (ni ondje nema Sidonije Štajner).

110 HR-HDA-252-RUR ŽO, 5074/1942; usp. DM AB, Sterbebuch, 29402/1942. On, supruga Zlata i sin Vladimir nisu registrirani među stradalima Srijema. Vidi: ŽIVKOVIĆ, Imenik stradalih osoba AP Vojvodine, 64-65. Nema ih ni u: „Popis žrtava rata 1941-1945.: Vojvodina” ni u: Jasenovac: žrtve rata, 770-771.

111 NJEGOVAN, Zločini okupatora i njihovih pomagača, 299; RS 002-183-PKRZ, Anketna komisija Vukovar, inv. br. 4817.

112 Gradski muzej Vukovar. Vidi faksimil u: DOBROVŠAK, Židovi u Srijemu, 269, 271. 
u prethodne deportacije. Odvedeni su potom u logor u Vinkovcima s najnužnijim stvarima, nešto novca i nakita. ${ }^{113}$ Prema procjeni Antuna Vilića i Đure Obersohna, tada je u Vinkovce odvedeno oko 200 vukovarskih Židova. ${ }^{114}$ Među uhićenima je bila i Jelena Malević r. Stern, pravoslavna Židovka, koja je kao takva puštena prije negoli je skupina upućena u vinkovački logor. $\mathrm{O}$ tijeku zbivanja posvjedočila je 1945. u Vukovaru pred gradskom Anketnom komisijom. Naznačila je da su nju pustili, a „sve druge odpremili su u logor u Vinkovce gde su bili nekoliko dana [sic!] a posle su upućeni u Zagreb, odakle su dalje odpravljeni za Njemačku". ${ }^{115}$ No iz prethodno navedenog izvješća Župske redarstvene oblasti Vukovar očito je da je početkom godine broj Židova u Vukovaru bio za 50-ak osoba veći. Razliku treba povezati s internacijama u Jasenovcu odnosno Staroj Gradiški koje su se zbile u proljeće 1942., ali i s izuzimanjem zdravstvenih radnika, među koje je spadao i Đuro Obersohn, te još nekih osoba iz mješovitih brakova, kojih je ukupno bilo 12-ak (poslijeratni podatci kažu: 4 muškarca i 8 žena), ili drugim pojedinačnim intervencijama. One su jednim dijelom uslijedile kasnije, u Vinkovcima i Zagrebu. ${ }^{116}$ Tako je primjerice otpuštena Jelena Bader r. Fischoff, stara 76 godina, majka Artura Badera, koji je bio zdravstveni vježbenik u Domu narodnoga zdravlja u Travniku. Njoj je dopušteno da otputuje sinu nakon intervencije iz Ministarstva zdravstva od 18. kolovoza 1942. godine. ${ }^{117}$ Četvero Židova, koji nisu bili obuhvaćeni internacijom u Vinkovcima vjerojatno uslijed skrivanja ili pokušaja bježanja, uhitila je Župska redarstvena oblast Vukovar te je skupina 3. kolovoza 1942., kako kažu podatci UNS-a, „upućena” u Jasenovac odnosno Staru Gradišku „na prisilni boravak”. ${ }^{118}$ I u prethodnome razdoblju bilo je nekoliko internacija Židova s vukovarskoga područja u logorima na području NDH, kao što je slučaj i s ostalim mjestima Srijema. Poznato je da je u ljeto 1941. osam Židova iz Vukovara bilo odvedeno u Gospić i na Pag, a poslije su vjerojatno barem neki od njih prebačeni u Jasenovac. ${ }^{119}$ Među deportacijama u Jasenovac poznata je i ona od 8. studenog 1941., kada je onamo upućena skupina imućnijih muškaraca koji su od 15. kolovoza 1941. bili zatočeni u vukovarskoj sinagogi. ${ }^{120}$ Stradali su uglavnom ubrzo po dolasku. Na postojećim popisima

113 NJEGOVAN, Zločini okupatora i njihovih pomagača, 299; RS 002-183-PKRZ, Anketna komisija Vukovar, inv. br. 4817.

114 BETHKE, (K)eine gemeinsame Sprache?, 334; DOBROVŠAK, Židovi u Srijemu, 283.

115 RS 002-183-PKRZ, Anketna komisija Vukovar, inv. br. 4817.

116 RS 002-183-PKRZ, Anketna komisija Vukovar, inv. br. 5159; KUMOVIĆ, Stradanje sremskih Jevreja, 91; DOBROVŠAK, Židovi u Srijemu, 274-281, 283.

117 HR-HDA-252-RUR ŽO, 5225/1942.

118 HR-HDA-252-RUR ŽO, 5033/1942 (Ljudevit Schwartz, Gyula i Roza Weiss, Getruda Koen).

119 RS 002-183-PKRZ, Anketna komisija Vukovar, inv. br. 5159. No na popisu Đ. Zatezala nalaze se četvorica ubijenih u Jadovnu i na Pagu (Slana): Baum Salamon, 26 g., Baum Franjo, 25 g., Baum (Salamon) Franjo, 46 g., Hercl (Mavro) Josip, 45 g. Vidi: ZATEZALO, Jadovno, knj. 1, 454-455.

${ }^{120}$ RS 002-183-PKRZ, Anketna komisija Vukovar, inv. br. 4817 i 5159. Ondje je 15. kolovoza 1941. bio zatočen 61 muškarac u dobi od 18 do 60 godina. Siromašniji su pušteni te su poslije 
Jasenovca krajem 1941. i početkom 1942. nalazi se tek 8 Židova iz Vukovara, uglavnom srednje ili starije dobi, od kojih je za trojicu naknadno naznačeno da su „umrli” tijekom studenoga ili u prosincu 1941., a među njima je bio i navodni vukovarski rabin Božidar Schlesinger. ${ }^{121}$ U proljeće 1942. uslijedila je druga grupna deportacija iz Vukovara u Jasenovac, posljednja prije akcije iz srpnja 1942. godine. ${ }^{122}$ Dakako, popisi zatočenika Jasenovca i Stare Gradiške iz 1941. i s početka 1942. nisu cjeloviti, a za kasnija razdoblja još su slabije sačuvani. Na popisima logora Đakovo nema nijedne Židovke iz Vukovara, a nema ih ni na popisima logora Danica, Gospić - Velebit - Pag i Loborgrad. ${ }^{123}$

Židovi iz Šida uhićeni su noću 26./27. srpnja 1942. te su odvedeni u dvorište šidske općine. Prema podatcima koji su nedavno detaljnije istraženi, u toj raciji uhićeno je 50-ak odraslih Židova, domicilnih stanovnika Šida, od njih ukupno 95 za koje je utvrđeno da su neposredno pred rat živjeli u Šidu. ${ }^{124}$ Odatle su u noći 27./28. srpnja u stočnim vagonima prebačeni u Vinkovce zajedno s iločkim Židovima. ${ }^{125}$ Dio tamošnjih Židova stradao je na drugim mjestima, a neki su se spasili bijegom. Tako je upravo na dan kad su provedena spomenuta uhićenja Estera Adler s djetetom pobjegla k sestri u Bačku. ${ }^{126}$

obavljali grobarske poslove u gradu (prilikom strijeljanja). O zatočenju imućnijih Židova u sinagogi do 8. studenog 1941., kad su deportirani u Jasenovac, svjedočila je Roza Obersohn (RS 002-183-PKRZ, inv. br. 4819).

${ }^{121}$ Možda je bio rabin u nekom ranijem periodu ili je riječ o pogrešci. Od 1934. do 1941. vukovarski rabin bio je dr. Izrael Isak Scheer, ubijen u srpnju 1941., vjerojatno u kompleksu Gospić-Velebit-Jadovno, ali između 1932. i 1934. nije bilo rabina (nakon smrti rabina Diamanta). Vidi: DOBROVŠAK, Židovi u Srijemu, 233-235, 273. Među stradalima u Jasenovcu, prema iskazu Jelene Malević, bili su: Štajner Hinko, Gros, Cajger, Bauk Hinko, Mandel, Šlezinger, Goldstein, Grin, Kraus, Rosenfeld, Đula Singer, Fischof i dr. (RS 002-183-PKRZ, Anketna komisija Vukovar, inv. br. 4817).

${ }^{122}$ RS 002-183-PKRZ, Anketna komisija Vukovar, inv. br. 4817.

${ }^{123}$ HR-HDA-421-JTH SRH, 4.3.3., B 124/1951, Popis zatočenika Jasenovca, 1-1454 i Popis interniranih Židova u Jasenovcu br. II, dne 24. oktobra 1941.; MILETIĆ, Koncentracioni logor Jasenovac, knj. 1, 117-148 („Spisak logoraša Koncentracionog logora Jasenovac”); HR-HDA1514-UPK NDH, Popis zatočenica u logoru Loborgrad (1-1032); VASILJEVIĆ, Sabirni logor Đakovo, 165-185; ZATEZALO, Jadovno, knj. 1, 454-455; DIZDAR, Logor Danica u Koprivnici, knj. 1, 532-538.

${ }_{124}$ SREMAC, KLEIN, Jevreji u Šidu, 47-53.

125 NJEGOVAN, Zločini okupatora i njihovih pomagača, 302. Usp. KUMOVIĆ, Stradanje sremskih Jevreja, 88.

126 Estera Adler rođena je oko 1912. u Šidu te je bila nastanjena u Šidu, kbr. 811. Svjedočila je da su Židovi iz Šida odvedeni u Vinkovce, a odatle u Jasenovac, ali nije jasno odakle joj to saznanje (nije isključeno da je to doznala upravo u Auschwitzu, kamo je dospjela 1944.). Vidi: RS 002-183-PKRZ, inv. br. 4887. Usp. SREMAC, KLEIN, Jevreji u Šidu, 80-86. Taj podatak preuzela je i pokrajinska komisija, koja zaključuje da su šidski Židovi odvedeni „preko Zagreba u Jasenovac" (NJEGOVAN, Zločini okupatora i njihovih pomagača, 302), te KUMOVIĆ, Stradanje sremskih Jevreja, 93. Šalić ju je identificirao kao Esteru Adler r. Epstein iz Vinkovaca, udanu za Maxa Adlera („odveden je u logor Jasenovac”, vjerojatno još 1941. jer nije na popisu iz svibnja 1942., op. a.), s kojim je imala kćer Katicu (nepoznate sudbine). Šalić kaže da se preselila u Šid te napominje da je preživjela Auschwitz. Vidi: ŠALIĆ, Židovi u Vinkovcima i okolici, 41. Suprug i ona prijavili su 20. lipnja 1941. imovinu u Vinkovcima, ali je vjerojatno prešla roditeljima nakon što je suprug odveden u Jasenovac (op. a.). 
Max Schrotmann sakrio se i uhvaćen je tek ujesen 1942., a Aleksandar Kohn pobjegao je s obitelji u Mađarsku i odatle je 1944. deportiran u Auschwitz. Neki su već prije pobjegli u Italiju ili Švicarsku, čak i Afriku, te su se tako spasili, a Salamon Malz, koji je pobjegao u Split, ubijen je u logoru u Zemunu. ${ }^{127}$

Akciju uhićenja i odvođenja iločkih Židova u Šid provela je 27. srpnja 1942. oružnička postaja iz Iloka prema naredbi izdanoj po Kotarskoj oblasti Ilok te su oni, kao i Židovi iz Vukovara, smjeli ponijeti „sav svoj novac i možebitne dragocjenosti”. ${ }^{128}$ Akcijom su obuhvaćeni ne samo Židovi iz mjesta Ilok nego i s područja kotara, uključujući i najmanja naselja (Neštin, Susek, Šarengrad, Sot, Čerević, Monoštor, Erdevik, Bingula, Monol i Molvin). ${ }^{129}$ Oružnička postaja Ilok dostavila je 27. srpnja 1942. Kotarskoj oblasti u Iloku popis 320 Židova koji se „dopremljuju kotarskoj oblasti u Vinkovce, sabirališnom logoru na igralištu sportskog kluba 'Cibalia', radi otpreme istih u dalje sabirne logore”. ${ }^{130}$ Naredbom kotarskoga upravitelja od uhićenja su bile izuzete obitelji liječnika Andrije Mandela, tiskara Mavre Epštajna i Nikole Mandela, oženjenog arijevkom, te kao pojedinac Vilim Fridman. ${ }^{131}$ Židovi s područja grada i kotara Ilok najprije su kamionima odvezeni u Šid, a odatle su noću 27./28. srpnja 1942. zajedno sa šidskim Židovima vlakom prebačeni u Vinkovce. ${ }^{132} \mathrm{~S}$ obzirom na to da je među njima bilo i težih bolesnika, neki su na putu za Vinkovce umrli, među njima Josip Weiss, Lea Ganz (Ganc) i Rudolf Vales (Wales), koji je u iskazima svjedoka naveden kao „stari Wales” jer je tada imao oko 72 godine. ${ }^{133}$ Neki Židovi iz Iloka već su prije dospjeli u logore Gospić - Velebit - Pag ili Jasenovac i Staru Gradišku. ${ }^{134}$ Ukupno ih je u Jasenovcu bilo u manjem broju nego iz pojedinih drugih mjesta sudeći prema onovremenim popisima logoraša. ${ }^{135}$ Neki su još 1942. i 1943. bili na životu (Abraham Stern, Jakob

127 Svjedočenje Abrahama Kišickog, u: BABIĆ, Zločini ustaša, 341; SREMAC, KLEIN, Jevreji u Šidu, 87-105; JIM, K-65-5-1/1.

${ }_{128}$ Sačuvani su izvornici Kotarske oblasti u Iloku i Oružničke postaje u Iloku, pohranjeni u Arhivu Vojvodine: RS 002-183-PKRZ, inv. br. 4832-4834, 4842-4843. Većinom su i objavljeni kao faksimili kod Kumovića. Usp. KUMOVIĆ, Stradanje sremskih Jevreja, 76-77, 87.

129 NJEGOVAN, Zločini okupatora i njihovih pomagača, 301. Pokrajinska komisija ne govori o brojevima iako je u izvornim dokumentima sačuvan podatak o broju uhićenih na tome području. Usp. KUMOVIĆ, Stradanje sremskih Jevreja, 87-88.

${ }^{130}$ RS 002-183-PKRZ, inv. br. 4832-4834, 4842. Usp. KUMOVIĆ, Stradanje sremskih Jevreja, 76-77.

131 RS 002-183-PKRZ, inv. br. 4842. Usp. KUMOVIĆ, Stradanje sremskih Jevreja, 87.

132 KUMOVIĆ, Stradanje sremskih Jevreja, 89.

${ }^{133}$ RS 002-183-PKRZ, inv. br. 4828, Ekspozitura Anketne komisije u Iloku, inv. br. 4828. Usp. NJEGOVAN, Zločini okupatora i njihovih pomagača, 302. Nesumnjivo je riječ o Rudolfu Valesu, rođenom oko 1870. godine. Kod Švob, kao i kod drugih autora koji preuzimaju te podatke iz baze JIM-a, uz ime Rudolfa Valesa navedeno je da je stradao u Jasenovcu. Usp. ŠVOB, Židovi u Hrvatskoj, knj. 2, 299-300. Kumović netočno donosi ime Lee Ganz (Leo!). Vidi: KUMOVIĆ, Stradanje sremskih Jevreja, 88. Usp. HR-HDA-1076-PONOVA, Prijave (Ilok), Ganc, Josip.

${ }^{134}$ Izrael Stern sa sinovima, Zekl Stern, Majer Stern, Jakob Vales i Mojša Stern. Vidi: RS 002-183-PKRZ, Ekspozitura Anketne komisije u Iloku, inv. br. 4828.

${ }^{135}$ Kao takvi registrirani su: Jakob Wales, Abraham Stern, Petar Stern, Ignac/Ignjat Stern i Izrael Stern. Usp. HR-HDA-421-JTH SRH, 4.3.3., B 124/1951, Popis zatočenika Jasenovca, 
Wales), a Petar Stern stradao je tek u proboju logoraša 1945. godine. ${ }^{136} \mathrm{~S}$ područja Iloka bilo je i dosta prebjega na područja pod talijanskom upravom, u talijanskim logorima za izbjeglice, koji su na taj način izbjegli deportacije, uz nekolicinu u Švicarskoj. ${ }^{137}$ Kotarska oblast iz Iloka početkom 1942. urgirala je pri Židovskom odsjeku u Zagrebu smatrajući da ima previše bježanja iločkih Židova u inozemstvo, najvećim dijelom mlađih, u „Ljubljansku pokrajinu”. ${ }^{138}$ Samo u logoru Ferramonti od 1941. do 1943. bilo je 12 izbjeglica iz Iloka koji su stigli tim putom. ${ }^{139} \mathrm{Na}$ području Italije bilo ih je u raznim izbjegličkim logorima najmanje 25. ${ }^{140}$ Nakon rata u Ilok se vratilo 15 -ak ili nešto više Židova iz izbjeglištva, partizana ili vojnoga zatočeništva. ${ }^{141}$

U Iloku i Šidu nalazilo se i 31 dijete iz Sarajeva, uzrasta od 3 do 14 godina, čiji su roditelji prije internirani u logorima na području NDH. Djecu su iz đakovačkoga logora preko Židovske bogoštovne općine u Osijeku primile pojedine obitelji u Iloku (22 djece) i Šidu (9 djece) na „privatnu skrb”, pa su bila raspoređena po kućanstvima. ${ }^{142}$ Većina je u srpnju 1942. dospjela u logor u Vinkovcima zajedno sa svojim skrbnicima. Ostaje otvorenim pitanje jesu li na popisu Oružničke postaje Ilok od 27. srpnja bila i ta sarajevska djeca, koju zapovjednik Šestan u dopisu upućenom Kotarskoj oblasti ne spominje, a koja su također bila sastavnim dijelom „vinkovačkoga” transporta. Kalmi Levi, tada star 15 godina, koji je bio udomljen u kući Winternitzovih u Iloku (bio je ondje smješten s braćom Avramom i Davidom Levijem, ali jedan od braće i on zatekli su se u Šidu, a za drugoga podatci nisu jasni), uspio se spasiti kod obitelji Bogdana Jovanovića iz Šida i tako izbjeći spomenuti transport. Obitelj Jovanović o njemu se skrbila do kraja rata, skrivajući mu identitet i koristeći se za njega krivotvorenim dokumentima. ${ }^{143}$

Židovi s područja kotara Županja uhićeni su po svemu sudeći također u srpnju 1942. godine. Kotarska oblast u Županji 4. kolovoza 1942. izvješćuje Župsku redarstvenu oblast, na prethodni zahtjev RAVSIGUR-a, „da su pokupljeni svi židovi [...] kotara te otpremljeni u sabirni logor u Vinkovcima”. ${ }^{144}$ Dvojica su Židova iz Gradišta kod Županje stradala već 1941. u lo-

1-1454 i Popis interniranih Židova u Jasenovcu br. II, dne 24. oktobra 1941.; MILETIĆ, Koncentracioni logor Jasenovac, knj. 1, 117-148 („Spisak logoraša Koncentracionog logora Jasenovac").

136 JIM, k. 65-5-1/1.

137 JIM, k. 65-5-1/1-297; SR-AJ-50, Predsedništvo Vlade, 50-4-9 (popis Židova u Švicarskoj).

138 HR-HDA-252-RUR ŽO, 493/1942.

139 Usp. RISTOVIĆ, U potrazi za utočištem, 91 i PIZZUTI, „Dalla Jugoslavia occupata”. Ristović kaže da ih je u logoru Ferramonti bilo 11.

140 PIZZUTI, „Dalla Jugoslavia occupata”.

141 ŠVOB, Židovi u Hrvatskoj, knj. 2, 301. Usp. SR-AJ-50, Predsedništvo Vlade, 50-4-9.

142 JIM, reg. br. 2510, k. 24-7-3/2, Popis sarajevske djece na privatnoj skrbi u Iloku i Šidu, sada u logoru u Vinkovcima.

${ }^{143}$ JIM, reg. br. 2510, k. 24-7-3/2. O obitelji Jovanović vidi: SREMAC, KLEIN, Jevreji u Šidu, 55-60.

${ }^{144}$ HR-HDA-252-RUR ŽO, 5156/1942. 
goru Slana te nisu bili registrirani ni u spisima Ureda za podržavljeni imetak (tzv. Ponova), koji je popisivanje židovske imovine obavio uglavnom tijekom lipnja 1941. godine. ${ }^{145}$ Iako se u izvješću Kotarske oblasti Županja te poslije u izvješćima Zemaljske komisije u vezi s tim stradanjima poimence spominju Slavonski Šamac, Štitar, Vrbanja i Županja, uhićenjima u srpnju 1942. bili su obuhvaćeni i Židovi iz drugih naselja toga područja. U Rajevu Selu, Babinoj Gredi, Gundincima i Drenovcima živjelo je nekoliko obitelji (15-ak osoba), a dvojica tamošnjih stanovnika (Ivan Gros i Đuro Stark) registrirani su među mrtvima u logoru Auschwitz. ${ }^{146}$ U Slavonskom Šamcu bilo je prije rata 13-ak Židova (4 obitelji), od kojih je barem desetero stradalo u Auschwitzu. ${ }^{147}$ Pri odvođenju u Vinkovce pobjegla je jedna Židovka, 20-godišnja Matilda Kohn iz Slavonskog Šamca. Druga, Elizabeta Spitzer iz Štitara, pokušala je počiniti samoubojstvo, ali je u tome spriječena. Njihova daljnja sudbina nije poznata. ${ }^{148}$ Makso Pollak i njegova supruga Edita iz Štitara bili su najvjerojatnije također internirani u logoru u Vinkovcima. U dokumentaciji Ponove sačuvana je bilješka prema kojoj Maksi 1942. nije mogla biti uručena neka odluka u vezi s podržavljenjem imovine jer se „nalazi u sabirnom logoru”. ${ }^{149} \mathrm{U}$ Račinovcima je sama živjela Helena Bauer te njezina daljnja sudbina nije poznata (ne nalazi se na popisima žrtava logora Jasenovac). U Vrbanji je bilo ukupno desetak Židova i svi su utovareni „u kamion i odveženi u Vinkovce”. ${ }^{150} \mathrm{Na}$ kraju, u samoj Županji bilo je nekoliko mješovitih obitelji (Preradin, Petrović, Schwartz) i dvije u kojima su oba partnera bili Židovi (Schön i Kon), ali su prešli na ka-

145 Ervin (Eugen) Laslo, 39 g. i Rudolf (David) Rasner, 49 g. Vidi: ZATEZALO, Jadovno, knj. 1, 584. U gradivu Ponove nisu evidentirane njihove obitelji (ako su bili oženjeni). Radi se o uredu koji je djelovao u okviru Ministarstva državne riznice pod nekoliko naziva, a najpoznatiji je po posljednjem, prihvaćenom početkom 1942., kao Ured za podržavljeni imetak. Prijave imovine sadržavaju podatke ne samo o prijaviteljima nego i o njihovoj djeci mlađoj od 21 godine te osnovne podatke o supružnicima. Usp. HEĐBELI, „Ponova”, 5-7; GOLDSTEIN, Holokaust u Zagrebu, 173-185.

146 Riječ je obiteljima Spitzer, Gross, Neumann te Đuri Starku i njegovoj sestri Beti Reiner sa kćerima (HR-HDA-1076-PONOVA, DKI 3246/5, 3243/4, 3245/4, 3248/1, 3579/1).

147 HR-HDA-306-ZKRZ, Guz, 2235/26-45.

148 HR-HDA-252-RUR ŽO, 5156/1942. Matilda Kohn ima više imenjakinja raznih dobi, iz drugih mjesta, koje su stradale u Jasenovcu (Židovska općina Zagreb, Popis žrtava lišenih života; „Poimenični popis žrtava KL Jasenovac 1941-1945.”). Primjeri pokazuju da su bjegunci koji su pokušavali izbjeći deportacije sprovedeni u Jasenovac, pa je to mogla biti i sudbina tih dviju Židovki.

149 HR-HDA-1076-PONOVA, DKI 3246/2. Odluka je vraćena 29. prosinca 1942. s tim obrazloženjem.

150 HR-HDA-306-ZKRZ, Guz, 2235/26-45. Lavoslav Šorš (Schorsch) još je 1941. počinio samoubojstvo ili je ubijen na putu u sabirni logor u Vinkovcima (podatci nisu ujednačeni), a dvoje neimenovanih iz Vrbanje preživjelo je rat (isti izvor). Prema iskazu Franje Dementa-Pepinog, članovi obitelji Grün (5 osoba), Singer (2) i Haimovich (2) deportirani su 1942. „u nepoznatom pravcu”. Vidi: ĆOSIĆ-BUKVIN, „Vrbanjci stradalnici Drugog svjetskog rata”, 37. U popisu Saveznoga zavoda za statistiku dio njih navodi se kao žrtve Jasenovca (Grün Baćko, Mervira, Sofija i Vilika); Jasenovac: žrtve rata, 1168-1169. 
toličanstvo. ${ }^{151}$ Ukupno je u čitavom kotaru početkom rata moglo biti 70 do 80 Židova, uključujući mješovite obitelji, a tom je akcijom bilo obuhvaćeno oko 50 osoba (bez pripadnika mješovitih obitelji). ${ }^{152}$

O odvođenju Židova s područja grada i kotara Bijeljina u vinkovački logor u postojećoj literaturi nema govora, no postoje dokazi da su i tamošnji Židovi obuhvaćeni tom „srijemskom” akcijom te da su deportirani u Auschwitz. Posljednja deportacija Židova iz Bijeljine organizirana je 1. kolovoza 1942. godine. ${ }^{153}$ Neki od odvedenih uspijevali su se javiti članovima obitelji, pa je to slučaj i s Rifkom Montiljo iz Bijeljine. Ona se 18. kolovoza 1942. javila dopisnicom sinu Moricu, koji je živio u Somboru, iz „Židovskog logora Vinkovci” ${ }^{154}$ U knjigama mrtvih u Auschwitzu registrirano je 5 osoba iz Bijeljine. Stoga je posve jasno da su točni podatci Abrahama Kišickog iz Šida, koji je kao zatočenik toga logora u svojem poratnom svjedočenju naveo da su i bijeljinski Židovi bili internirani na igralištu „Cibalije” u Vinkovcima. ${ }^{155}$ Brojčani podatci o tome koliko ih je odvedeno u Vinkovce nisu poznati. Pred rat je ondje živjelo (oko) 280 Židova. ${ }^{156}$ Dio je registriran u pojedinima od logora na području NDH. Što se tiče kompleksa Gospić - Velebit - Pag, na popisu Đ. Zatezala nalazi se tek jedan Židov iz Bijeljine (sic!). ${ }^{157} \mathrm{U}$ sačuvanim popisima Jasenovca bilo je u pojedinim razdobljima, u jesen i zimu 1941./1942., čak oko 55 muških osoba, a u popisima logora Loborgrad bilo je u proljeće 1942. registrirano 16 židovskih žena iz Bijeljine različitih dobnih skupina, dovedenih također 1941. (i nijednoga djeteta!). Neke su žene i djeca mogli stradati i ranije (u logorima iz kojih su dovedeni), a popisi Jasenovca i Gradiške nisu potpuni, pa se opravdano može pretpostaviti da je broj onamo dovedenih bijeljinskih Židova bio veći. Manji broj žena nalazi se i na popisima logora Đakovo (samo njih 5 ili 6), a većina je ondje i umrla. Među njima su neke prije bile dovedene u Staru Gra-

151 Prema podatcima iz Muzeja Vojvodine, u njihovoj kartoteci članovi obitelji Kohn iz Županje (Adolf, Ana, Aladar, Gizela, Jakob i Velimir, Žiga, Etelka i Emil) zavedeni su kao strijeljani 1942. u Jasenovcu. Podatci se temelje na popisima odbora Saveza boraca Narodnooslobodilačkog rata. Samo je manji dio članova te obitelji evidentiran u Ponovi. Otprilike polovica njih evidentirana je u popisu žrtava rata iz Muzeja genocida (prema popisu Saveznoga zavoda za statistiku iz 1964.), ali su zato neki navedeni dvaput (Adolf, Ana, Žiga, Etelka i Emil). Kao mjesto stradanja naveden je Jasenovac. Usp. „Popis žrtava rata 1941.-1945.: SR Hrvatska” (Županja).

152 Kumović tvrdi da su županjski Židovi odvedeni u Jasenovac, ali ne navodi izvor za to. Usp. KUMOVIĆ, Stradanje sremskih Jevreja, 96-97.

153 PINTO, Zločini okupatora i njihovih pomagača, 414; TAUBER, Holokaust u Bosni i Hercegovini, 563.

154 JIM, reg. br. 4736, k. 24-7-3/3.

155 Prema podatcima M. Kumovića, u toj su akciji bijeljinski Židovi preko Sremske Rače deportirani za Jasenovac, što nije točno, kako se vidi iz ovdje navedenog. Kumović ne navodi izvor za svoju tvrdnju. Usp. KUMOVIĆ, Stradanje sremskih Jevreja, 96. Možda je riječ o nekom od prethodnih odvođenja (op. a.).

156 Pinto i Tauber donose identičan podatak. PINTO, Zločini okupatora i njihovih pomagača, 412; TAUBER, Holokaust u Bosni i Hercegovini, 211.

157 Samuel (Josip) Alijas, 41 g., ubijen na Velebitu. Usp. ZATEZALO, Jadovno, knj. 1, 423. 
dišku, odakle su u veljači ili ožujku 1942. prebačene u Đakovo. ${ }^{158}$ Dio Židova pobjegao je u partizane, gdje su ili zbog čega su neki također stradali, a dio se spasio bijegom na područje izvan teritorija NDH, kao i u drugim mjestima. ${ }^{159}$

\section{Sabirni logor u Vinkovcima i transport upućen u Auschwitz}

U Vinkovcima je postojalo nekoliko mjesta na kojima se 1941. i 1942. privremeno interniralo židovsko stanovništvo prije njihova deportiranja u logore. Tijekom 1941. za te potrebe korišteni su Židovski dom i sinagoga, u kojoj su u više navrata bili internirani muškarci, kako je o tome posvjedočio Ivan (Ilan) Borovic. Odatle su neki odvedeni u Jasenovac u studenom 1941., a ubrzo nakon toga sinagoga je srušena. ${ }^{160}$ Veća skupina Židova s područja grada i kotara Vinkovci bila je u svibnju 1942. privremeno internirana u zgradi Hrvatskoga sokola, u četvrti Lenije uz rijeku Bosut, o čemu svjedoči više preživjelih osoba. Odatle su nakon nešto više od dva tjedna odvedeni u Jasenovac i Staru Gradišku. ${ }^{161}$ Kao mjesto internacije spominje se i zgrada Monopola, koja je od 1943. bila u funkciji njemačkoga sabirnog logora, a u svibnju 1944. prelazi u nadležnost ustaških vlasti. ${ }^{162}$ O korištenju te zgrade za dulju i opsežniju internaciju Židova 1942. nema konkretnijih pokazatelja, osim jednoga iskaza prema kojemu su se odatle 20. kolovoza 1942. javili članovi obitelji Polaček iz Rume. ${ }^{163}$ Budući da se zgrada nalazila uz željezničku prugu, vjerojatno je bila mjesto ukrcaja Židova pred polazak u Auschwitz jer svi drugi pokazatelji govore da su rumski, kao i ostali srijemski Židovi od sredine srpnja do 19. kolovoza 1942. bili internirani na igralištu „Cibalije”, na drugome kraju grada. ${ }^{164}$

158 HR-HDA-1514-UPK NDH, Popis zatočenica u logoru Loborgrad (1-1032); JIM, reg. br. 4736, k. 24-7-3/3; HR-HDA-1514-UPK NDH, Popis žena i djece koji su stigli u Đakovo 26. veljače i 6. ožujka 1942. i Popis umrlih u logoru Đakovo. Usp. VASILJEVIĆ, Sabirni logor Đakovo, 190, 191, 194.

159 Usp. TAUBER, Holokaust u Bosni i Hercegovini, 210, 212 i SR-AJ-50, Predsedništvo Vlade, 50-4-9. Među njima je i obitelj Švicer, Artur, Frida i njihov sin Mladen, koji su se spasili bijegom u Švicarsku.

160 ŠALIĆ, Židovi u Vinkovcima i okolici, 55-58, 400, 401. Ivan (Ilan) Borovic (Vinkovci, 31. svibnja 1921. - ?) bio je sin Armina i Margit Borovic r. Schreiber, a uspio se spasiti bijegom u talijansku zonu uz pomoć lažnih dokumenata, kao i čitava obitelj. Godine 1951. iselili su se u Izrael (Isto, 59-62).

161 Svjedok iz Vinkovaca, koji kaže da su u logor odvedeni dva dana nakon uhićenja, očito griješi. Usp. Isto, 436.

162 Zgrada je od 1943. služila kao njemački sabirni logor za antifašiste i sudionike Narodnooslobodilačke borbe, a od svibnja 1944. bila je u nadležnosti RAVSIGUR-a. Kroz logor je prošlo oko 4600 zatočenika (PUŠKAR, KORDA, Vinkovački kraj, 137-144).

163 ŠALIĆ, Židovi u Vinkovcima i okolici, 438. To je bio datum ukrcaja u vlak, pa su se mogli javiti tom prilikom. Do tada su rumski Židovi više od mjesec dana boravili na igralištu „Cibalije”, kako kaže Adam Unterberger. Monopol kao mjesto zatočenja Židova 1942. navodi i Koljanin, koji kaže da su vinkovački Židovi onamo dovedeni iz zgrade Hrvatskoga sokola radi ukrcaja u vlak (poziva se na Šalića). Usp. KOLJANIN, „Jevreji žrtve rata 1941.-1945.”, 187.

164 Šalić u vezi s internacijom vinkovačkih Židova sugerira mogućnost da su nakon zatočenja u zgradi Hrvatskoga sokola prebačeni na igralište „Cibalije” (sic!) te onda u zgradu 
Već je naznačeno da su podatci u vezi s internacijom srijemskih Židova u Vinkovcima u literaturi neujednačeni. Romano kaže da je „Tolj internirao vinkovačke Jevreje pod vedrim nebom, na nogometnom igralištu kluba 'Cibalia”, te da je ondje zatočio 400 Židova iz Vinkovaca, nakon čega je pristupio „čišćenju Srema od Židova”. ${ }^{165} \mathrm{Na}$ te se podatke nadovezuju i drugi autori. Kumović, spajajući konstatacije Romana i Šalića, zaključuje da su vinkovački Židovi bili zatočeni u zgradi Hrvatskoga sokola, potom u skladištu Monopola, te odatle na stadionu „Cibalije” (sic!), a 20./21. kolovoza bili su deportirani u Jasenovac i Staru Gradišku s drugim srijemskim Židovima (sic!). ${ }^{166}$ Romano dalje navodi da su na tome igralištu bili internirani Židovi iz „Vinkovaca [sic!], Rume, Sremske Mitrovice, Neština, Suseka, Čerevića, Erdevika, Monoštra i još nekih drugih manjih mesta" ${ }^{167}$ Židove iz Šida i Vukovara, kao ni one iz Županje i Bijeljine, uopće ne spominje. Svjedočenja pohranjena u Arhivu Vojvodine, kao i završni elaborat pokrajinske komisije za utvrđivanje ratnih zločina Vojvodine, govore o dovođenju na igralište „Cibalije” Židova iz Rume (oko 17. srpnja), Mitrovice (nije naveden datum dovođenja), Vukovara (26. srpnja), Šida i Iloka (28. srpnja). Nakon koncentracije srijemskih Židova iz spomenutih mjesta kontingent je dopunjen Židovima iz Bijeljine i Županje, a možda i manjim brojem Židova iz Stare Pazove. O njima govori Abraham Kišicki. ${ }^{168}$ Elaborat pokrajinske komisije osvrće se na prethodna zbivanja u Staroj Pazovi tako što upozorava na deportaciju 63 tamošnjih Židova u Jasenovac i Staru Gradišku u svibnju 1942. godine. Kasnije razdoblje posebno ne komentira. ${ }^{169}$ Kišicki se osvrće i na sudbinu vinkovačkih Židova te izrijekom kaže da nisu bili ondje. Kaže da su „po čuvenju [...] već pre toga bili prikupljeni i odvedeni”, što odgovara podatcima koji su ovdje već izneseni. Zemunske Židove ne spominje. ${ }^{170} \mathrm{Na}$ kraju je na igralištu „Cibalije”, prema svjedočenju Kišickog, bilo zatočeno oko 1000 osoba. ${ }^{171}$

Monopola do ukrcaja u vlak. Isto povezuje i sa Židovima iz Rume, a o internaciji ostalih srijemskih Židova na igralištu „Cibalije” ne govori. Šalić se na jednome mjestu nadovezuje i na Lengel-Krizman, povezujući zgradu Monopola s internacijom Židova iz Đakova. No ona za đakovačke Židove kaže da su u Vinkovcima bili u lipnju 1942. „konfinirani [...] npr. na prostoru kudjeljare Zimmermann" zbog radova na poljoprivrednim dobrima te da su poslije prebačeni u Tenju. Usp. LENGEL-KRIZMAN, „Prilog proučavanju terora u tzv. NDH”, 9-10; ROMANO, Jevreji Jugoslavije, 111; ŠALIĆ, Židovi u Vinkovcima i okolici, 436, 438.

165 ŠALIĆ, Židovi u Vinkovcima i okolici, 191, 253, 280, 434, 436.

166 KUMOVIĆ, Stradanje sremskih Jevreja, 90. Donosi točan datum zatočenja (4. svibnja 1942.), ali i netočan datum deportacije, koji potječe od Romana. Usp. ROMANO, Jevreji Jugoslavije, 111; KOLJANIN, „Jevreji žrtve rata 1941.-1945.”, 187.

${ }_{167}$ ROMANO, Jevreji Jugoslavije, 111. Neštin, Susek, Čerević, Erdevik i Monoštor mjesta su s područja tadašnjega kotara Ilok. Usp. VELZEK, Popis imena mjesta u Nezavisnoj Državi Hrvatskoj, 80, 133, 321, 449.

168 Svjedočenje Abrahama Kišickog, u: BABIĆ, Zločini ustaša, 340.

169 NJEGOVAN, Zločini okupatora i njihovih pomagača, 299.

170 Svjedočenje Abrahama Kišickog, u: BABIĆ, Zločini ustaša, 340.

171 Isto. Čitavo svjedočenje Kišickog objavili su u prijepisu i Sremac i Klein, ali s jednom pogreškom. Oni navode da je u Vinkovcima bilo zatočeno 100 osoba (sic!). Usp. SREMAC, KLEIN, Jevreji u Šidu, 100. Primjerak dokumenta nalazi se u Arhivu Jugoslavije (SR-AJ-110- 
Logorom je upravljala Ispostava Župske redarstvene oblasti Vinkovci, a zapovjednik je bio policijski agent Grubišić iz Vinkovaca. Židov Leopold Hirt (Hirth) iz Vukovara bio je nadležan za unutarnji red i nabavu hrane kao starješina logora. ${ }^{172}$ Zatočenici su bili grupirani po kotarevima te su raspolagali stvarima za spavanje (jastucima, plahtama, pokrivačima), pomoću kojih su improvizirali šatore i tako pokušavali zaštititi najslabije članove obitelji. ${ }^{173}$ Odmah po dolasku morali su predati sve dragocjenosti, tj. zlatne ili srebrne predmete, te satove i nalivpera, kako kaže Kišicki. ${ }^{174}$ Higijenski uvjeti bili su lošiji nego u sokolskome domu jer nije bilo tekuće vode, a poljski zahodi, koje su iskopali zatočenici, bili su malobrojni. Zatočenici su dnevno odlazili na radove u mjestu. Muškarci su radili u gradskoj elektrani, raščišćavali ruševine plinare, radili na željezničkoj stanici i u predionici („pređari”) Hen, gdje su istovarivali drva, te su kopali grobove za osobe koje su strijeljane „po ustašama”. Žene su čistile „ustaške stanove i kancelarije”. ${ }^{175} \mathrm{U}$ nabavu hrane odlazili su pod pratnjom. Nabava je bila ograničena na kupovinu kupusa i bundeva od kojih su pripremani obroci, a krumpir, grah, slaninu ili mast nisu mogli kupiti (manje količine donijeli su od kuće). Pored toga logorašima su dnevno dodjeljivane minimalne porcije kruha i čaja. Hranu su plaćali vlastitim novcem u iznosu od $20 \mathrm{kn}$ dnevno po osobi. ${ }^{176}$

Pred sam polazak transporta Vilko Kühnel, šef Židovskoga odsjeka RAVSIGUR-a u Zagrebu, uputio je 17. kolovoza 1942. u Vinkovce savjetnika Dragana Albrechta kao svojega delegata u okviru spomenute akcije. ${ }^{177}$ Priprema transporta započela je 18. kolovoza navečer. Tom je prilikom naređeno da ondje internirani Židovi predaju preostali novac. ${ }^{178}$ Albrecht, kojega Abraham Kišicki spominje kao „nekog nadsavetnika iz Zagreba” čijega se imena nije mogao sjetiti, bio je zadužen za prikupljanje novca i pratnju transporta do Zagreba. ${ }^{179}$ Nakon što su već zapakirali prtljagu naređeno je da se riješe jastuka te higijenskih potrepština, tako da su se pripreme za put, uz pojedinačno pretraživanje kojemu su bili podvrgnuti, razvukle na čitav dan. ${ }^{180}$ Ukrcavanje u vagone, u kojima je bilo smješteno po 50 -ak osoba prema svjedočenju

DKRZ, 110-690-742, 98-100). Prema svjedočenju Adama Unterbergera, radilo se o oko 1200 transportiranih iz Vinkovaca u Auschwitz. Vidi: RS 002-183-PKRZ, inv. br. 4855.

172 Svjedočenje Abrahama Kišickog, u: BABIĆ, Zločini ustaša, 341.

173 Isto, 340.

174 Isto, 341 .

175 Isto, 340

176 Isto, 340-341; RS 002-183-PKRZ, inv. br. 4855, Svjedočenje Adama Unterbergera.

177 HR-HDA-252-RUR ŽO, 5138/1942. Dragan Albrecht (Zagreb, 3. studenog 1883. - Zagreb /?/, ?) završio je Pravni fakultet u Zagrebu te radio u sudstvu od 1906., a od 1912. u državnoj upravi. Od 15. studenog 1941. odjelni savjetnik u MUP-u NDH (prije toga u Državnom ravnateljstvu za Ponovu). Umirovljen je ujesen 1943. zbog bolesti. Vidi: HR-HDA-223-MUP NDH, Personalni dosje, br. 8309.

178 Svjedočenje Abrahama Kišickog, u: BABIĆ, Zločini ustaša, 341.

179 HR-HDA-252-RUR ŽO, 5138/1942; Svjedočenje Abrahama Kišickog, u: BABIĆ, Zločini ustaša, 341 .

${ }^{180}$ Svjedočenje Abrahama Kišickog, u: BABIĆ, Zločini ustaša, 341. 
Kišickog, odnosno 80-ak, kako kaže Adam Unterberger iz Rume, započelo je navečer, ali transport je iz Vinkovaca krenuo sljedećega jutra. ${ }^{181}$ Intervencijama u Vinkovcima i Zagrebu pojedinci su izuzeti iz transporta. Kišicki navodi da je bio među 20 -ak osoba koje su izuzete u Vinkovcima. Unterberger je s transportom prošao kroz Zagreb te svjedoči da je ondje izuzeto još 20 -ak osoba. ${ }^{182}$ Većinom se radilo o osobama iz mješovitih brakova, ali i drugima koji su izuzeti uslijed ,inih okolnosti” ${ }^{183}$ Oni su u Zagrebu prebačeni u zatvor na Savskoj cesti, a odatle su pušteni početkom rujna 1942. na nalog Vjekoslava Pavera, predstojnika Ureda I. UNS-a. ${ }^{184}$ Među izuzetima iz transporta bio je i Leopold Hirth. ${ }^{185}$ Postoje i dva svjedočenja koja se odnose na Židove iz Iloka i Šida. Leopold Štern iz Iloka, koji je od početka 1942. bio u bijegu u Mađarskoj, u Bonyhádu (iz Mađarske je 1944. deportiran u Auschwitz), saznao je da je veći dio iločkih Židova „nesposobnih za rad” iz Zagreba upućen u Jasenovac, gdje su ubijeni. Prema njegovim saznanjima, samo su „specijalni radnici” iz Iloka odvedeni u „Njemačku na rad”. ${ }^{186}$ Pored Kišickog, koji je pušten iz transporta u Vinkovcima, o sudbini šidskih Židova svjedočila je Estera Adler iz Šida. Ona nije bila internirana u logoru u Vinkovcima, nego se na dan odvođenja tamošnjih Židova uspjela spasiti bijegom sestri u Bačku. Za obitelji uhićene u raciji od 27. srpnja 1942. navela je da su stradale u Jasenovcu te da su onamo odvedene iz logora u Vinkovcima (sic!). ${ }^{187}$ Nije isključeno da su oni dijelom ondje i odvedeni, ali tek iz Zagreba, zajedno s iločkim Židovima.

${ }_{181}$ Isto; RS 002-183-PKRZ, inv. br. 4855, Svjedočenje Adama Unterbergera. Usp. KUMOVIĆ, Stradanje sremskih Jevreja, 97.

182 Svjedočenje Abrahama Kišickog, u: BABIĆ, Zločini ustaša, 341; RS 002-183-PKRZ, inv. br. 4855, Svjedočenje Adama Unterbergera.

183 HR-HDA-252-RUR ŽO, 5381/1942.

${ }^{184}$ Isto. Ured I. UNS-a bio je nadležan za logore, a Paver mu je bio na čelu od svibnja 1942. do 1945. godine. Usp. KOVAČIĆ, Redarstveno-obavještajni sustav Nezavisne Države Hrvatske, 152-155.

185 Svjedočenje Abrahama Kišickog, u: BABIĆ, Zločini ustaša, 341. Postojala su dvojica istoga imena, obojica iz Vukovara. Ovdje je vjerojatno riječ o Leopoldu Hirthu/Hirtu, rođenom 1883. u Vukovaru, izvozniku poljoprivrednih proizvoda, koji se sa suprugom Olgom i sinom Franjom (rođenim 1913.) doselio u Vukovar 30. travnja 1941. iz Pančeva. Poslije su pobjegli u Primorje te su svi troje preživjeli u partizanima. Prije toga bili su zatočenici logora Kraljevica i Rab. Kod Romana je naveden kao bankar (sic!) iz Beograda rođen 1882. u Vukovaru. Vidi: ROMANO, Jevreji Jugoslavije, 390; ŠVOB, Židovi u Hrvatskoj, knj. 2, 606, 613. Postoje dvije prijave imovine na ime Hirth, Leopold iz Vukovara (2 osobe). Usp. HR-HDA-1076-PONOVA, Prijave (Vukovar).

186 RS 002-183-PKRZ, Ekspozitura Anketne komisije u Iloku, inv. br. 4828. Čitav njegov iskaz od 10. kolovoza 1945. obiluje detaljima. O ovome kaže da zna „iz raznih obaveštenja i korespondencije [...] da su koncem jula svi Jevreji od najstarijih do najmlađih odvedeni iz Iloka u Šid, a od tamo vozom u Vinkovce. [...] Iz Vinkovaca su otpremljeni u Zagreb, nakon što u Vinkovcima ostali 3 nedelje pod vedrim nebom. Iz Zagreba je jedan deo t.j. oni koji su bili specijalni radnici odveden u Nemačku na rad, a ostali u Jasenovac u logor. Od svih ovih niko se do danas nije vratio ili javio".

187 Estera Adler posvjedočila je to i za Jakoba Francoza (navodi ga pod imenom Janko [sic!] Francoz), tvrdeći da je odveden u Jasenovac zajedno sa suprugom i devetero djece, no njegovo je ime zabilježeno u knjigama mrtvih u Auschwitzu. Vidi: RS 002-183-PKRZ, Ekspozitura Šid, br. 82/1945, Svjedočenje Estere Adler; SREMAC, KLEIN, Jevreji u Šidu, 47-50, 80-87. 
To inače nije bila logika kojom su se rukovodili Nijemci u organizaciji transporta za Auschwitz, jer su pod krinkom „preseljenja” u njih bile uključene čitave obitelji. No moguće je da je broj osoba koje su planirane za preostala dva transporta u nekoliko sljedećih dana (Židovi dovedeni iz logora Tenja, dio žena iz Loborgrada) sa Židovima koji su tada krenuli iz Sarajeva prema Zagrebu i Loborgradu prelazio okvirni broj od 2000 osoba, a da nije dosegnut broj od dodatnih 1000 osoba za još jedan transport, onaj od 30. kolovoza 1942., koji je u posljednjem poznatom rasporedu transporta bio naveden kao opcionalan. ${ }^{188}$ Romano je naime na temelju jednoga dokumenta iz arhiva nekadašnjega Vojnoistorijskog instituta utvrdio da su zadnji preostali Židovi iz Sarajeva odvedeni 20. i 22. kolovoza 1942. u dvije manje skupine u smjeru Loborgrada, a odatle u Auschwitz (četvrtim ili/i petim transportom, op. a). ${ }^{189}$ O izdvajanju dijela iločkih i šidskih Židova dvojica svjedoka iz logora u Vinkovcima (Kišicki i Unterberger) ne govore ništa, pa ostaje otvorenim pitanje o čemu je točno bila riječ.

Transport je svakako 20. kolovoza napustio područje NDH, a u Auschwitz je stigao 22. kolovoza. ${ }^{190}$ Adam Unterberger, čije je svjedočenje dosta kratko i usredotočeno na razdoblje po dolasku u Auschwitz, kaže da se putovalo tri dana te da su putem „mnogi” umrli. ${ }^{191}$ Podatci o umrlima tijekom transporta nisu sačuvani u službenoj dokumentaciji logora (niti je poznato da su prikupljani). Po dolasku je iz transporta, koji po njegovu iskazu obuhvaćao 1200 ljudi, izdvojeno „120 mladića i jačih ljudi i zanatlija”. To je evidentno precijenjen broj s obzirom na to da dokumenti logora Auschwitz govore o 110 muškaraca. ${ }^{192}$ Muškarcima su dodijeljeni logorski brojevi u rasponu od 60609 do 60718, a izdvojeno je i 86 žena s brojevima od 17920 do $18005 .{ }^{193}$ Pod br. 60710 u Auschwitzu je bio evidentiran Adolf Unterberger iz Rume. ${ }^{194}$ Njegova kasnija sudbina nije poznata, ali je vrlo vjerojatno da je preživio te da

188 Prema podatcima Lengel-Krizman i Dizdara, zatočenice iz logora Loborgrad otpremljene su u Auschwitz transportima od 13., 20., 24. i 28. kolovoza 1942. godine. Vidi: LENGEL-KRIZMAN, „Prilog proučavanju terora u tzv. NDH”, 20; DIZDAR, „Logori na području sjeverozapadne Hrvatske", 95. Usp. HR-HDA-252-RUR ŽO, 5939-5942, 5955/1942.

189 ROMANO, Jevreji Jugoslavije, 132. U Sarajevu je nakon toga ostalo oko 120 Židova iz mješovitih brakova.

${ }^{190}$ O tome svjedoči zatočenički karton Adolfa Unterbergera, na kojemu je upisan datum dolaska u logor (DM AB, Personalbogen, Unterberger, Adolf). Odvođenje Židova iz srijemskih mjesta u Auschwitz spominje i Šosberger, ali kao datum dolaska navodi 26. kolovoza 1942. (sic!). Vidi: ŠOSBERGER, Jevreji u Vojvodini, 190.

191 DM AB, Personalbogen, Unterberger, Adolf.

192 RS 002-183-PKRZ, inv. br. 4855, Svjedočenje Adama Unterbergera. Usp. KUMOVIĆ, Stradanje sremskih Jevreja, 97.

193 CZECH, Auschwitz Chronicle, 225. Danuta Czech, autorica dosad najcjelovitije kronologije deportacija u logor Auschwitz, kaže da nije poznat ukupan broj pridošlih tim transportom niti koliko ih je odmah po dolasku ubijeno u plinskim komorama. U izvatku njezine tablice transporta za Auschwitz dvoje mlađih autora u jednoj je kasnijoj publikaciji uvrstilo broj od 3500 (sic!) dovedenih iz „Jugoslavije” 22. kolovoza 1942., ali to odudara od onoga što iznosi Czech. Vidi: DĘBSKY et al., Death Books from Auschwitz, vol. 1: Reports, 178.

194 DM AB, Personalbogen, Unterberger, Adolf. 
je identičan s Adamom Unterbergerom, odnosno da je promijenio ime nakon rata. ${ }^{195}$ Nesposobni za rad, starci, žene i djeca, prema Unterbergerovu iska$\mathrm{zu}$, „natovareni su na kamione, odvedeni u gasne komore, potom spaljeni”. ${ }^{196}$ S njime je dovedena i supruga Terezija Unterberger r. Müller, koja je vjerojatno stradala u selekciji odmah pri dolasku u logor. U logoru Auschwitz stradao je i Adolfov sin Josip, rođen 1927. ili 1928. godine. ${ }^{197}$ Neki od uključenih u rad u logoru umrli su tijekom rujna i listopada 1942. te su bili registrirani u knjigama mrtvih (Sterbebücher). Ondje se nalaze imena 88 osoba, od ukupno 196 s područja Srijema i Bijeljine, koje su bile pošteđene smrti u plinskim komorama pri dolasku transporta (vidi prilog 1). Bili su podrijetlom s područja današnjega hrvatskog Srijema: iz Iloka (28 osoba), Neština (2) i Šarengrada pokraj Iloka (1), Vukovara (16) i Opatovca pokraj Vukovara (2), Županje (1), Vrbanje (1), Drenovaca (1), Rajeva Sela (1), Slavonskog Šamca (2) i Štitara pokraj Županje (1), zatim srpskoga Srijema: iz Hrvatske (Srijemske) Mitrovice (5), Grgurevaca pokraj Mitrovice (1), Rume (15) i Šida (6) te iz Bijeljine u sjeveroistočnoj Bosni (5). U Auschwitzu u knjigama mrtvih nema popisanih osoba iz Stare Pazove, a razlozi se mogu naći u malom broju deportiranih (ako su bili internirani u Vinkovcima).

Broj od 1200 osoba upućenih u Auschwitz prema svjedočenju Adama Unterbergera za 200 je veći od broja o kojemu govori Abraham Kišicki. Unterbergerova procjena u ovom je segmentu vjerojatno pretjerana jer njemačka izvješća govore o 5000 deportiranih 1942. iz NDH. Prema tome, prosječan broj osoba u pet tada otpremljenih transporta s područja NDH iznosio je oko $1000 .{ }^{198}$

\section{Udio Židova prema mjesnoj pripadnosti u transportu za Auschwitz od 20. kolovoza 1942.}

Brojčani sastav ovoga transporta po mjesnoj pripadnosti može se preciznije utvrditi tek dijelom. Znamo ga za većinu mjesta približno, a ostatak se temelji na procjeni u odnosu na prethodni broj i dotadašnju sudbinu Židova. Broj uključenih u transport uglavnom je odgovarao preostalom broju Židova

\footnotetext{
195 Adolf Unterberger iz Rume, rođen 24. 6. 1905. u Rumi, bio je sin Josefa Unterbergera (pok.) i Salli r. Pellus. Vidi: DM AB, Personalbogen, Unterberger, Adolf; HR-HDA-1076-PONOVA, Prijave (Ruma), Unterberger, Adolf. Adolfovo ime ne nalazi se na popisima stradalih. Vjerojatno je preživio i promijenio ime (po dobi i imenu sina odgovarao bi Adamu).

196 RS 002-183-PKRZ, inv. br. 4885. Usp. PIPER, „The Methods of Mass Murder”, 142-143, 170-173.

${ }^{197} \mathrm{DM}$ AB, Personalbogen, Unterberger, Adolf. U Imeniku stradalih ne navodi se Josip, ali je naveden u popisu iz 1964., no s netočnom godinom rođenja, kao Unterberger (Adam) Jozef iz Rume rođen 1925. (sic!), stradao 1942. u Auschwitzu. Usp. ŽIVKOVIĆ, Imenik stradalih osoba AP Vojvodine, 408; „Popis žrtava rata 1941-1945.: Vojvodina”, opština Ruma, naselje Ruma, 318.

198 To odgovara i dnevnom prosjeku ostalih transporta koji su tada stizali u Auschwitz. Usp. PIPER, „The Methods of Mass Murder”, 164.
} 
na području obuhvaćenom akcijom iz srpnja i kolovoza 1942., s iznimkom Stare Pazove, Vinkovaca i Zemuna, odakle su Židovi gotovo u cjelini prethodno upućeni u Jasenovac odnosno Staru Gradišku, te Hrvatskih (Srijemskih) Karlovaca, odakle su još u ožujku upućeni u logor Zemun. Radilo se o osobama uhićenima u pojedinim mjestima Srijema koja su već navedena (Ilok, Vukovar, Ruma, Mitrovica i Šid te manji broj Židova iz Stare Pazove), kao i ostatku židovske zajednice iz Bijeljine.

Ukupan broj Židova na području Srijema iznosio je prema podatcima iz Jevrejskoga narodnog kalendara za 1938./1939. oko 2200 osoba. ${ }^{199}$ Raniji podatci o broju Židova u pojedinim kotarevima i gradovima Srijema, kao i Bijeljine, poznati su iz popisa stanovništva provedenog 1931. godine. Broj Židova iznosio je tada nešto više od 2600 (usp. tablicu 1). ${ }^{200}$ Godine 1941. trebalo je ponovno provesti popis stanovništva, ali je to ometeno ratnim zbivanjima. Zato se koristimo različitim izvorima i procjenama iz razdoblja 1940. - 1941., pa i nekih prijašnjih godina, uglavnom Jevrejskim kalendarom, ali i drugim sličnim publikacijama bogoštovnih općina odnosno Saveza jevrejskih općina. Prema tim izvorima, broj Židova u pojedinim kotarevima s pripadajućim gradovima ili općinama bio je nešto manji u odnosu na popis iz 1931. godine. $\mathrm{S}$ druge strane u statistici Saveza rabina za pojedina mjesta 1941. (Zemun, Vinkovci, Vukovar) broj Židova znatnije odskače od toga. O stranim izbjeglicama u tim općinama nema mnogo podataka. ${ }^{201}$ Moguće je da su statistikom Saveza rabina pokrivena šira područja, ali i da podatcima iz Jevrejskoga kalendara nisu obuhvaćena djeca. Svakako treba uzeti u obzir da se u državnoj statistici, Jevrejskom kalendaru i podatcima Saveza rabina kao Židovi ne prikazuju osobe koje su se asimilirale odnosno promijenile vjeroispovijest, prihvaćajući vjeroispovijest bračnih partnera. Za njih su vrijedili kriteriji utvrđeni 1941. zakonskim odredbama NDH koje su oblikovane u skladu s njemačkim rasnim propisima. Osobe koje su prema tome bile „mojsijeve vjere” po rođenju ili vjerskoj pripadnosti predaka prvoga i drugoga koljena (npr. troje baka i

199 DOBROVŠAK, Židovi u Srijemu, 206.

${ }^{200}$ Definitivni rezultati popisa stanovništva od 31 marta 1931 godine, VIII-IX, XII.

201 Savez rabina za 1941. godinu govori o 1200 Židova u Zemunu, 1000 u Vinkovcima te 600 u Vukovaru. Citirano prema: DOBROVŠAK, Židovi u Srijemu, 259. Izbjeglice s područja pod kontrolom Njemačkoga Reicha u tim mjestima ne spominju se (u literaturi koja se bavila tim temama) osim nekolicine u Vinkovcima te u Zemunu. Oni su odvedeni zajedno s domaćim Židovima (usp. bilj. 70 i 82). Usp. RISTOVIĆ, U potrazi za utočištem, 23-82; GRUENFELDER, „Nepoželjni gosti”, 303-362; GRUENFELDER, Sustigla ih Šoa, passim; BETHKE, (K) eine gemeinsame Sprache?, 235-238, 357-363, 404. Bethke kaže da je na području Kraljevine Jugoslavije 1941. bilo 4000-6000 stranih izbjeglica, od toga samo u Zagrebu 2500-3000, a nakon 10. travnja 1941. preostalo ih je 1400 (BETHKE, (K)eine gemeinsame Sprache?, 357-358). Zagrebačka židovska općina brinula se o emigrantima iz Austrije, Njemačke i Češke (u više izbjegličkih logora i Zagrebu), a od lipnja 1941. dio brige prepustila je drugim općinama. Kad je riječ o Srijemu, to se odnosi na Rumu. Prema podatcima koje za pojedina mjesta donosi Goldstein, njihov ukupni zbroj iznosio je 1941. godine oko 1400 osoba, ali prema jednome dokumentu bilo ih je 1800. Većina izbjeglica stradala je u holokaustu, kao i domaći Židovi, a tek dio je uspio pobjeći ili se spasiti skrivanjem (GOLDSTEIN, Holokaust u Zagrebu, 131, 241, 244, 436, 534 i dr.). 
djedova) smatrane su Židovima, odnosno nearijevskim „državnim pripadnicima” te su, bez obzira na promjenu vjere, bile podvrgnute progonu. ${ }^{202}$ Autori koji su se bavili Srijemom pridržavali su se uglavnom brojeva sličnih u većem broju izvora ako nisu sami došli do novih podataka (kao što je Sremac došao u slučaju Šida, Šalić za Vinkovce te Dobrovšak za Ilok i Vukovar). Za potrebe ovoga rada preuzeti su njihovi podatci, ali su i dopunjeni na temelju onovremenih dokumenata i drugih izvora. Broj Židova u pojedinim kotarevima bio je moguće nešto manji u odnosu na popis iz 1931. (npr. Ruma, ali podatci nisu dodatno istraživani u novije vrijeme), ali većinom je ipak očit rast broja židovskoga stanovništva (kotarevi/gradovi: Srijemski /Hrvatski/ Karlovci, Zemun, kotarevi: Ilok, Stara Pazova, Šid). Broj Židova u Srijemu mogao je 1941. prema tome iznositi minimalno oko 2800, a prema većim brojevima za pojedina mjesta mogao je dosezati i do 4000.

Tablica 1. Broj Židova na području Srijema i u Bijeljini prema popisu stanovništva 1931., stanje 1941. te podatci o uhićenjima i smjeru deportacija od svibnja do kolovoza 1942.

\begin{tabular}{|l|c|c|c|}
\hline $\begin{array}{l}\text { Kotar } \\
\text { i/ili grad }\end{array}$ & $\begin{array}{c}\text { Broj Židova } \\
\text { prema popisu } \\
\text { stanovnika } \\
\mathbf{1 9 3 1 .}\end{array}$ & $\begin{array}{c}\text { Broj Židova } \\
\mathbf{1 9 4 1 . . ^ { 2 0 3 }}\end{array}$ & $\begin{array}{c}\text { Podatci o uhićenjima i smjeru } \\
\text { deportacije od svibnja do } \\
\text { kolovoza 1942. }\end{array}$ \\
\hline $\begin{array}{l}\text { Ilok } \\
\text { kotar) }\end{array}$ & $\mathbf{3 7 7 ^ { 2 0 4 }}$ & $\begin{array}{c}\text { preko 400 } \\
\text { domaćih } \\
\text { Židova }\end{array}$ & $\begin{array}{c}\text { Auschwitz i Jasenovac } \\
\text { (320 domaćih Židova te 20 } \\
\text { djece iz Sarajeva, vjerojatno } \\
\text { ukupno 340 osoba) }\end{array}$ \\
\hline
\end{tabular}

${ }^{202}$ Zakonska odredba o državljanstvu, Zakonska odredba o rasnoj pripadnosti i Zakonska odredba o zaštiti arijevske krvi i časti hrvatskog naroda (Narodne novine $16 / 1941 /$ ). Sve su proglašene 30. travnja 1941. godine. Usp. GOLDSTEIN, Holokaust u Zagrebu, 119-121.

${ }^{203} \mathrm{Za}$ broj Židova u pojedinim mjestima 1941. treba uzeti u obzir objašnjenja u tekstu i bilješkama koje prate tablicu.

${ }^{204}$ Kod Švob je pogreškom naveden nešto veći broj (397). Vidi: ŠVOB, Židovi u Hrvatskoj, knj. 2, 284.

${ }^{205}$ Dobrovšak za Ilok citira podatke Pinkasa jevrejskih opština i Jevrejskoga kalendara iz 1940. (310 Židova) te navodi brojeve koji se odnose na one koji su bili registrirani kod vjerskih općina (posebno Ilok te posebno Erdevik), ali i administrativne općine Ilok, kojoj pripadaju oba mjesta (DOBROVŠAK, Židovi u Srijemu, 251, 257, 258). Međutim, u popisu stradalih donosi znatno veći broj Židova koji su ondje živjeli 1941. (377) (Isto, 299-309). Tome treba pribrojiti odbjegle, zatočene u vojnim logorima i sl. te one koji su eventualno iz popisa izostali. Primjerice, obitelj Winternitz, čija se tri člana kod Dobrovšak navode među stradalima (majka Rifka i dvoje neimenovane djece), imala je osmero djece: Benjamin/Wolf (r. 1923.), Elizer/Laza (r. 1924.), Hani (r. oko 1925.), Rohil (r. oko 1927.), Estera (r. oko 1928.), Cipora (r. oko 1929.), Rezika (r. oko 1933.), Mirjam (r. oko 1940.). Vidi: HR-HDA-1076-PONOVA, P obrasci (Ilok), Winternitz Aleksander. Kod Švob se nalaze imena oko 365 Židova iz Iloka, stradalih i preživjelih. I ona navodi tri člana obitelji Winternitz među stradalima (dvoje djece bez imena) te jednoga preživjelog, Lazara, rođenog 1924. (ŠVOB, Židovi u Hrvatskoj, knj. 2, 285-301). Preživjeli su još i otac obitelji Aleksandar Winternitz te sin Benjamin/Wolf, rođen 1923. Vidi: PIZZUTI, „Dalla Jugoslavia occupata”. Po svemu sudeći, uz majku su stradale sve 


\begin{tabular}{|c|c|c|c|}
\hline $\begin{array}{l}\text { Kotar } \\
\text { i/ili grad }\end{array}$ & \begin{tabular}{|c|} 
Broj Židova \\
prema popisu \\
stanovnika \\
1931. \\
\end{tabular} & $\begin{array}{c}\text { Broj Židova } \\
1941 .^{203}\end{array}$ & $\begin{array}{c}\text { Podatci o uhićenjima i smjeru } \\
\text { deportacije od svibnja do } \\
\text { kolovoza } 1942 .\end{array}$ \\
\hline \begin{tabular}{|l|} 
Irig \\
(kotar)
\end{tabular} & 7 & $?$ & $?$ \\
\hline $\begin{array}{l}\text { Ruma } \\
\text { (kotar) }\end{array}$ & 261 & $\begin{array}{c}\text { 249? domaćih } \\
\text { Židova }^{206} \\
\text { 200-300? stranih } \\
\text { izbjeglica } \\
\end{array}$ & $\begin{array}{l}\text { Auschwitz (156, većinom } \\
\text { domaćih Židova) }\end{array}$ \\
\hline $\begin{array}{l}\text { Srijemska } \\
\text { (Hrvatska) } \\
\text { Mitrovica } \\
\text { (kotar i grad) } \\
\end{array}$ & $\begin{array}{l}137 \text { (kotar 22, } \\
\operatorname{grad} 115)\end{array}$ & $116(\operatorname{grad} ?)^{207}$ & $\begin{array}{l}\text { Auschwitz (50, odnosno } \\
37 \text { nakon puštanja } \\
13 \text { pojedinaca) }\end{array}$ \\
\hline $\begin{array}{l}\text { Srijemski } \\
\text { (Hrvatski) } \\
\text { Karlovci (grad) } \\
\end{array}$ & 2 & $15^{208}$ & - \\
\hline $\begin{array}{l}\text { Stara Pazova } \\
\text { (kotar) }\end{array}$ & 88 & 80-100? ${ }^{209}$ & $\begin{array}{c}\text { Jasenovac (63 osobe); } \\
\text { Auschwitz (15-20 osoba?) }\end{array}$ \\
\hline Šid (kotar) & 63 & $\begin{array}{l}95 \text { domaćih } \\
\text { Židova }\end{array}$ & $\begin{array}{c}\text { Auschwitz i Jasenovac } \\
\text { (50-ak domaćih Židova i } \\
9 \text { djece iz Sarajeva, } \\
\text { ukupno oko } 60 \text { osoba) }\end{array}$ \\
\hline $\begin{array}{l}\text { Vinkovci } \\
\text { (kotar i grad) }\end{array}$ & $\begin{array}{c}732 \text { (kotar } 85 \\
\operatorname{grad} 647)\end{array}$ & $550-1000 ?^{211}$ & Jasenovac (358) \\
\hline
\end{tabular}

kćeri (bilo ih je šest). U Popisu iz 1964. („Popis žrtava rata 1941.-1945.: SR Hrvatska”, opština Vukovar, naselje Ilok, 2727) evidentirana je među stradalima samo Rifka Winternitz i jedno neimenovano dijete (stradali u Jasenovcu).

206 Dobrovšak za Rumu donosi podatke o 249 Židova prema Jevrejskom narodnom kalendaru 1939.-1940. (DOBROVŠAK, Židovi u Srijemu, 259). Isto je kod Romana (ROMANO, Jevreji Jugoslavije, 93).

${ }^{207}$ Prema Jevrejskom narodnom kalendaru 1939.-1940., u Mitrovici je bilo 116 Židova. DOBROVŠAK, Židovi u Srijemu, 258. Prema izvještaju Pokrajinske komisije za ratne zločine, u „varoši je bilo svega 70 duša” (NJEGOVAN, Zločini okupatora i njihovih pomagača, 283). Prema svjedočenju Mirjam Vajs, ondje je prije rata živjelo 84 Židova.

${ }^{208}$ Svih 15 osoba (pet obitelji iz Inđije i Beške) odvedeno je u ožujku 1942. u Zemun (HRHDA-252-RUR ŽO, 4200/1942).

${ }^{209}$ Podatci se temelje na procjeni autorice na osnovi uvida u kartoteku i dosjee konfiscirane imovine (HR-HDA-1076-PONOVA, DKI dosjei) Židova s područja Stare Pazove, u kojima su navedena imena 80 -ak osoba. U spisima Ponove ni za jedno mjesto nisu evidentirane sve osobe (neki su izbjegli dati prijavu, starci i djeca starija od 21 godine bez imovine i sl.), pa je to potrebno uzeti u obzir.

210 SREMAC, KLEIN, Jevreji u Šidu, 47-50.

211 Šalić na jednome mjestu procjenjuje da je taj broj mogao iznositi oko 550 osoba (zaključujući to prema podatcima iz Ponove), a na drugome govori o 640 Židova „uoči progona 1941.” (ali taj dio možda se odnosi na pripadnike bogoštovne općine, a ona je uključivala i Županju). Usp. ŠALIĆ, Židovi u Vinkovcima i okolici, 407, 441. Prema Jevrejskom narodnom kalendaru, u Vinkovcima je bilo oko 630 Židova. Usp. DOBROVŠAK, Židovi u Srijemu, 220, 259. Zemaljska 


\begin{tabular}{|c|c|c|c|}
\hline $\begin{array}{l}\text { Kotar } \\
\text { i/ili grad }\end{array}$ & $\begin{array}{c}\text { Broj Židova } \\
\text { prema popisu } \\
\text { stanovnika } \\
1931 .\end{array}$ & $\begin{array}{c}\text { Broj Židova } \\
1941 .^{203}\end{array}$ & $\begin{array}{c}\text { Podatci o uhićenjima i smjeru } \\
\text { deportacije od svibnja do } \\
\text { kolovoza } 1942 .\end{array}$ \\
\hline $\begin{array}{l}\text { Vukovar } \\
\text { (kotar i grad) }\end{array}$ & $\begin{array}{c}336(\text { kotar 30, } \\
\operatorname{grad} 306)\end{array}$ & $\begin{array}{c}\text { preko } \\
300-600 ?^{212}\end{array}$ & Auschwitz (177) \\
\hline $\begin{array}{l}\text { Zemun } \\
\text { (kotar i grad) }\end{array}$ & $\begin{array}{l}532(\operatorname{kotar} 9, \\
\operatorname{grad} 523)^{213}\end{array}$ & $600-1200 ?^{214}$ & Jasenovac (oko 680?) \\
\hline Županja (kotar) & 88 & $70-80 ?^{215}$ & Auschwitz (50-ak) \\
\hline Bijeljina (kotar) & 326 & oko 280 ? $^{216}$ & $\begin{array}{l}\text { Auschwitz (broj nije točno } \\
\text { poznat, vjerojatno više od 100) }\end{array}$ \\
\hline
\end{tabular}

komisija za utvrđivanje zločina okupatora i njihovih pomagača donosi podatke o 730-750 Židova u Vinkovcima (to odgovara podatcima iz predratnoga popisa stanovništva). Vidi: HRHDA-306-ZKRZ, Guz, 2235/26-45. Broj od 1000 Židova navodi Savez rabina (usp. bilj. 201).

${ }^{212}$ Prema podatcima iz Jevrejskoga narodnoga kalendara na koje upućuje Dobrovšak, u Vukovaru je 1938. živjelo 289, a 1939. - 1941. godine 213 Židova (DOBROVŠAK, Židovi u Srijemu, 206, 218). U veljači 1942. prema „rasnim” kriterijima bilo je ondje 230 Židova (115 obitelji). Vidi faksimil dokumenta iz Gradskoga muzeja Vukovar u: DOBROVŠAK, Židovi u Srijemu, 271. Treba uzeti u obzir da je barem 50-ak osoba prije internirano u logorima na području NDH te da su neki Židovi iz Vukovara pobjegli, pa je broj Židova na području kotara zasigurno (možda i znatno) prelazio 300 (to potvrđuje i velik broj prijava imovine u fondu Ponove). Tome u prilog govore i podatci M. Švob, koja navodi imena 244 stradalih iz Vukovara te 53 preživjelih, čemu treba pribrojiti barem 17 preživjelih iz Italije (koji nisu u njezinu popisu) itd. Vidi: ŠVOB, Židovi u Hrvatskoj, knj. 2, 602-613; PIZZUTI, „Dalla Jugoslavia occupata”. Broj od 600 Židova navodi Savez rabina (usp. bilj. 201).

${ }^{213}$ Prema podatcima D. Fogela (FOGEL, Jevrejska zajednica u Zemunu, 22), u Zemunu je u međuraću bilo oko 600 Židova. To preuzimaju KUMOVIĆ, Stradanje sremskih Jevreja, 93 i DOBROVŠAK, Židovi u Srijemu, 254.

${ }^{214}$ Pokrajinska komisija za utvrđivanje ratnih zločina na području Vojvodine u svojem elaboratu kaže da je 29. srpnja 1942. iz Zemuna u Jasenovac deportirano 450 Židova (NJEGOVAN, Zločini okupatora i njihovih pomagača, 298-299), uz napomenu da je prije rata u Zemunu bilo oko 600 Židova (te podatke koriste Kumović i Fogel, prije već navedeni). Izvješće Komisije za utvrđivanje ratnih zločina donekle je proturječno jer uz spomenuti broj deportiranih 29. srpnja 1942. (450) kaže i da se u vagonima nalazilo po 40 osoba (15 vagona $\times 40$ osoba po vagonu daje zbroj od 600). No ako broju deportiranih s kraja srpnja (minimalno 450) pribrojimo odvedene transportima 8. lipnja i 1. srpnja 1942. (ukupno 232 osobe), prema podatcima iz Židovskoga odsjeka RAVSIGUR-a (HR-HDA-252-RUR ŽO, 4328/1942, 4538/1942), te nekolicinu onih koji su deportirani krajem kolovoza, kao i 10 Židova, pripadnika mješovitih brakova, izuzetih 1942., taj bi broj iznosio oko 700 (ako ne i više) osoba $s$ područja grada i kotara Zemun. Dobrovšak preuzima Fogelov podatak o ukupno 574 stradale osobe s ovoga područja (domaći Židovi i strani izbjeglice). Broj od 1200 Židova navodi Savez rabina (usp. bilj. 201).

${ }^{215}$ Podatci Zemaljske komisije za utvrđivanje zločina okupatora i njihovih pomagača (HRHDA-306-ZKRZ, Guz, 2235/26-45) dopunjeni su onima iz fonda Ponove.

${ }^{216}$ Taj podatak donose Pinto i Tauber. Rat je prema njima preživjelo 26 Židova iz Bijeljine (PINTO, Zločini okupatora i njihovih pomagača, 413; TAUBER, Holokaust u Bosni i Hercegovini, 210). 
Što se tiče grada i kotara Vinkovci, Šalić prema podatcima iz fonda Ponove procjenjuje da je ondje moglo biti oko 550 Židova, ali na drugome mjestu govori o 640 osoba (taj veći broj moguće uključuje i one s područja kotara Županja, koji su pripadali Židovskoj bogoštovnoj općini Vinkovci). ${ }^{217} \mathrm{Kad}$ se oduzmu oni koji su uspjeli izbjeći deportacije, a njih je poznato 80 -ak, preostali Židovi gotovo su svi stradali u logorima Jasenovac i Stara Gradiška, kamo su odvedeni u nekoliko navrata tijekom 1941. i 1942. godine. Slično je i s gradom i kotarom Zemun. Ondje su se glavne deportacije židovskoga stanovništva odvijale u srpnju i kolovozu 1942., kada je njih najmanje oko 680 (koliko bi ih trebalo biti kad se saberu podatci iz korištenih izvora) deportirano $\mathrm{u}$ Jasenovac i Staru Gradišku. ${ }^{218} \mathrm{Ti}$ podatci nadilaze procjene o broju Židova u Zemunu iz literature koja je navedena, pa je moguće da uključuju i dio stranih izbjeglica u Zemunu. Židovski stanovnici Srijemskih Karlovaca, kojih je bilo 15-ak, otpremljeni su u ožujku 1942. u logor Zemun. Židovi iz Stare Pazove odvedeni su početkom svibnja 1942. u većem broju u Jasenovac i Staru Gradišku (63 osobe) te ih je maksimalno 15-20 u kolovozu moglo biti uključeno u deportaciju za Auschwitz (ako su podatci Abrahama Kišickog o njihovu zatočenju na igralištu „Cibalije” točni). Podatci o Židovima iz Stare Pazove koji su izbjegli deportacije te eventualnim stranim izbjeglicama na tome području nisu poznati. Kad je riječ o Židovima iz Iloka, njihov je broj prema podatcima predratnoga Jevrejskoga narodnoga kalendara iz 1939. iznosio 310 osoba (160 Aškenaza i 150 ortodoksnih), a isti je bio i 1940. prema podatcima Pinkasa jevrejskih opština. ${ }^{219}$ Prema podatcima o stradalima za vrijeme rata koje je prikupila Dobrovšak, njih je bilo 377. Ako se tome pribroje podatci o osobama koje su se spasile bijegom ili preživjele u vojnom zatočeništvu i sl., broj Židova nastanjenih u Iloku 1941. trebao bi iznositi najmanje 400 osoba. ${ }^{220}$

Broj(evi) Židova uhićenih u srpnju i kolovozu 1942. s namjerom da budu upućeni u Auschwitz koje relativno pouzdano znamo jesu: 320 osoba iz Iloka i 50-ak iz Šida te s njima 29 sarajevske djece raspoređene kod iločkih i šidskih obitelji (nije posve jasno je li 20 djece iskazano u prethodnome broju od 320 uhićenih u Iloku, ali u Sidu svakako broju od 50-ak uhićenih Židova treba pribrojiti 9 djece đakovačkih zatočenica iz Sarajeva jer je R. Sremac obradio samo domaće Židove), 156 Židova iz Rume, 177 Židova iz Vukovara, 50-ak iz Županje, 50 iz Hrvatske (Srijemske) Mitrovice i vjerojatno 15-20 iz Stare Pazove. Ukupni zbroj za ta mjesta iznosio bi oko 850-860 osoba (možda nešto više). Preostali dio trebao bi obuhvatiti Židove iz Bijeljine. Pored domaćih Židova evidentno je ovim transportom obuhvaćen i dio stranih izbjeglica, u

\footnotetext{
${ }^{217}$ Iako je pripadala Židovskoj bogoštovnoj općini Vinkovci, Županja je i 1931. i 1941. bila poseban administrativni kotar. Vidi: ŠVOB, Židovi u Hrvatskoj, knj. 2, 559; ŠALIĆ, Židovi u Vinkovcima i okolici, 407, 441. Zato su i brojevi iz Jevrejskoga kalendara veći (630 Židova).

${ }^{218}$ Podatci za Zemun s kraja srpnja 1942. neujednačeni su i u izvješćima Komisije za utvrđivanje zločina okupatora i njihovih pomagača, što je već komentirano.

219 DOBROVŠAK, Židovi u Srijemu, 220 (tablica), 251.

${ }^{220}$ Isto, 299-309; ŠVOB, Židovi u Hrvatskoj, knj. 2, 301; PIZZUTI, „Dalla Jugoslavia occupata”.
} 
međuraću nastanjenih na području Rume. K tome je najmanje 40-ak osoba (a vjerojatno i nešto više) bilo izuzeto iz transporta u Vinkovcima i Zagrebu, kako svjedoče Abraham Kišicki i Adam Unterberger. Nakon svega, treba uzeti u obzir i svjedočenje Leopolda Šterna o izdvajanju dijela iločkih Židova u Zagrebu i njihovu preusmjeravanju u Jasenovac. Tvrdnja Estere Adler da su šidski Židovi odvedeni iz Vinkovaca u Jasenovac nema potvrdu u iskazu Abrahama Kišickog, ali i nju treba uzeti u obzir ako se poveže s iskazom Leopolda Šterna. Ako su vraćeni u Jasenovac, to je moglo biti samo djelomično, iz Zagreba. Zbog svega toga Sremac je, pišući o Židovima iz Šida, bio oprezan s njihovim atribuiranjem logorima Jasenovac i Auschwitz. Upozorio je na to da je Auschwitz bio mjesto deportiranja Židova uhićenih 27. i odvedenih 28. srpnja 1942. iz Šida u Vinkovce, ali ga je kao nedvojbeno mjesto stradanja naveo isključivo uz imena onih 6 osoba koje su evidentirane u knjigama mrtvih toga logora. Uz imena ostalih stavio je odrednicu „logor” bez daljnje specifikacije. ${ }^{21}$

\section{Zaključak}

Transport upućen iz Vinkovaca u Auschwitz 19. odnosno 20. kolovoza 1942., kamo je stigao 22. kolovoza 1942., bio je dosad tek djelomično obrađen, uglavnom vezano uz žrtve iz srpskoga dijela Srijema. No i ondje ima pogrešaka u podatcima koji se na njega odnose. Ovdje provedenom analizom trebalo bi biti jasnije što se događalo sa Židovima na području čitavoga Srijema, ne samo onih koji su bili internirani na igralištu „Cibalije” u Vinkovcima u srpnju i kolovozu 1942. te odatle odvedeni u logor Auschwitz (Vukovar, Županja, Ruma, Srijemska Mitrovica, dio iz Iloka i Šida) nego i u drugim mjestima za koja pouzdano znamo da su Židovi odatle od svibnja do srpnja 1942. stradali u Jasenovcu i Staroj Gradiški (Vinkovci, Zemun, Stara Pazova). Nakon usporedbe brojčanoga stanja židovskoga stanovništva u pojedinim mjestima s podatcima o prethodnim internacijama u različitim logorima na području NDH (tijekom 1941. i 1942.) te dokumentima i svjedočenjima koja se odnose na razdoblje od svibnja do kolovoza 1942., evidentno je da je holokaust na području Srijema većinom tada i proveden odvođenjem Židova u logore Jasenovac, Stara Gradiška i Auschwitz. Dobiva se potpuniji uvid i u zbivanja na području Bijeljine, koja je također obuhvaćena ovom akcijom. Odatle su Židovi u više navrata tijekom 1941. i 1942. odvođeni u logore na području NDH, a preostali su prikupljeni 1. kolovoza 1942. te dovedeni u logor na

${ }^{221}$ RS 002-183-PKRZ, Anketna komisija Vukovar - Ekspozitura Šid, br. 82/1945; SREMAC, KLEIN, Jevreji u Šidu, 38, 51-53, 84-86. Moguće je da su nešto o izdvajanju dijela iločkih i šidskih Židova i njihovu preusmjeravanju u Jasenovac Štern i Adler čuli i u logoru Auschwitz. Oboje su onamo dospjeli 1944. godine. Tada je bila živa nekolicina logoraša koji su u logor stigli transportima iz Osijeka u kolovozu 1942., npr. Dragutin Glasner iz Donjeg Miholjca te Arnold Kohn i Željko Perlstein iz Osijeka. Usp. ŽIVAKOVIĆ-KERŽE, Stradanja i pamćenja, $142,143,282$. 
igralištu „Cibalije” radi priključivanja planiranome transportu za Auschwitz. U postupcima deportacije u ovdje obrađenom razdoblju osobe iz mješovitih brakova te članovi obitelji zdravstvenih radnika bili su većinom izuzeti, kako se prakticiralo i prije tijekom 1942. godine. Pokušaji bijega i skrivanja bili su strogo kažnjeni, pa je tijekom odvijanja akcije više osoba zbog toga upućeno u Jasenovac ili Staru Gradišku. ${ }^{222}$ Podatci koji su prikupljeni trebali bi se odraziti na dopunu i ispravke popisa žrtava za pojedina mjesta. Kad je riječ o hrvatskim područjima, to se prvenstveno odnosi na Vukovar i Ilok. Dio žrtava iz nekih mjesta nije dosad uopće bio evidentiran niti ih se povezuje s ijednim od logora. To se posebice odnosi na područje Županje, odakle Židovi gotovo da i nisu na popisima stradalih. Podatke za žrtve s područja Vinkovaca i Zemuna (stradali u Jasenovcu i Staroj Gradiški) također je moguće provjeriti i dopuniti ili korigirati prema ovdje navedenim popisima. ${ }^{223}$

${ }^{222}$ RS 002-183-PKRZ, inv. br. 4843 (usp. bilj. 100); HR-HDA-252-RUR ŽO, 5033/1942 (usp. bilj. 118).

${ }^{223}$ Podatci iz popisa koje je sastavio UNS točniji su naspram ostalih popisa (imena, godine i mjesta rođenja deportiranih, no imena su dijelom zabilježena fonetski). Među onima koji se ne nalaze primjerice u bazi „Poimenični popis žrtava KL Jasenovac 1941-1945.” za Vinkovce su: Grün Emanuel (r. 1876.), Jaffa Josip (r. 1888.), Lion Ružica (r. 1907.), Lion Ružica (r. 1924.), Lion Terezija (r. 1922.), Lion Matilda (r. 1921.) i dr. 
Prilog 1. Popis umrlih iz transporta upućenog u Auschwitz 19./20. kolovoza 1942. iz Vinkovaca prema podatcima iz knjiga mrtvih KL AuschwitzBirkenau ${ }^{224}$

\section{Bijeljina}

Baruch, Zadik, trgovac iz Bijeljine, rođen 28. 6. 1898. u Bijeljini, roditelji: Zadik Baruch i Rahela r. Altavar, supruga: Berta r. Pijade. Umro 17. 9. 1942. (31279/1942).

Levi, Floriska, krojačica iz Bijeljine, rođena 8. 11. 1919. u Bijeljini, roditelji: Salamon Levi i Rahela r. Alkalaj. Umrla 21. 9. 1942. (32038/1942).

Montilija (Montiljo?, op. a.), Lidija, rkt., učenica iz Bijeljine, rođena 23. 8. 1929. u Beogradu, roditelji: Aron Montilija i Irena r. Bararon. Otac Aron Montilija interniran je u Jasenovcu. ${ }^{225}$ Umrla 3. 10. 1942. (34428/1942).

Papo, Klarica, bez zanimanja, iz Bijeljine, rođena 27. 6. 1922. u Tuzli, roditelji: Elisch Papo i Regina r. Alkalaj (oboje nastanjeni u Tuzli). Umrla 24. 9. 1942. (32601/1942).

Papo, Renee, iz Bijeljine, rođena 31. 12. 1915. u Budimpešti, roditelji: Licco Eskenasy (Budimpešta) i Janka r. Kolos (Bečkerek), suprug: Josef Papo. Umrla 28. 10. 1942. (37874/1942).

\section{Ilok}

Bresslauer, Samuel, trgovac iz Šarengrada, rođen 2. 12. 1910. u Šarengradu, roditelji: Šandor Bresslauer i Risa r. Perles. Umro 26. 9. 1942. (32973/1942).

Ehrenfeld, Salamon, poljoprivrednik iz Iloka, rođen 1. 10. 1925. u Iloku, roditelji: Emanuel Ehrenfeld i Juliška r. Stern. Umro 21. 9. 1942. (32057/1942).

Franzos, David, radnik iz Iloka, rođen 7. 6. 1892. u Iloku, roditelji: Efraim Francoz i Fanny r. Stern, supruga: Julijana r. Fein. Umro 30. 9. 1942. (33787/1942).

Funk, Heinrich, knjigoveža iz Iloka, rođen 14. 3. 1900. u Iloku, roditelji: Jakob Funk i Adela r. Kritzler. Umro 9. 9. 1942. (29516/1942).

\footnotetext{
${ }^{224}$ Prikazani su abecedno unutar tadašnjih kotareva NDH. U zagradi je izvorna oznaka upisa iz knjiga mrtvih koje se čuvaju u Državnome muzeju Auschwitz-Birkenau (DM AB, Sterbebücher) u Oświęcimu (Poljska) za svaku navedenu osobu. Uz imena roditelja navedeno je njihovo posljednje boravište (ako nije identično boravištu preminule osobe). Imena osoba navedena su u pravilu kako su zabilježena u izvornicima (bez dijakritičkih znakova i s raznim manjim pogreškama), osim za prezime Zilzer.

${ }^{225}$ Opsežniji osobni podatci zatočenika u Auschwitzu (zanimanje, adresa stanovanja, imena roditelja, supružnika i broj djece, posljednje boravište svih spomenutih, datum dolaska u logor) prikupljani su pri registraciji novopridošlih zatočenika koji su trebali poslužiti kao radna snaga u logoru (tj. onih koji nisu odmah ubijeni). Lidija Montilija, dajući podatke o roditeljima, navela je Jasenovac kao posljednje boravište oca. Prema uobičajenoj proceduri, podatak je iz njezina zatočeničkoga kartona preuzet u knjigu mrtvih (osobni kartoni u većini slučajeva nisu sačuvani).
} 
Goldenberg, Eizik, poljoprivrednik iz Iloka, rođen 10. 10. 1920. u Iloku, roditelji: Abraham Goldenberg i Rosa r. Gross. Umro 6. 9. 1942. (28293/1942).

Goldenberg, Heskel, poljoprivrednik iz Iloka, rođen 15. 9. 1922. u Iloku, roditelji: Abraham Goldenberg i Regina (Rosa?, op. a.) r. Gross. Umro 10. 10. 1942. (35122/1942).

Goldenberg, Miša, poljoprivrednik iz Neština, rođen 16. 7. 1889. u Stojkofalvi (?), ${ }^{226}$ Mađarska, roditelji: Bernhard Goldenberg i Lotte r. Engel, supruga: Laura r. Steinlauf. Umro 15. 10. 1942. (36084/1942).

Goldenberg, Salamon, poljoprivrednik iz Neština, rođen 15. 7. 1914. u Nyrbatoru, roditelji: Abraham Goldenberg i Regina r. Gross. Umro 20. 9. 1942. (32023/1942).

Hendler, Pero, postolar iz Iloka, rođen 12. 8. 1913. u Iloku, roditelji: Anton Hendler i Rosalia r. Rotmann. Umro 27. 9. 1942. (33014/1942).

Herskovic, Samuel, poljoprivrednik iz Iloka, rođen 16. 2. 1903. u Beregszaszu (Berekszasz), Mađarska, roditelji: Chaim Herskovic i Seba r. Rosenberg (Antwerpen), supruga: Juliana r. Gelb. Umro 19. 10. 1942. (36759/1942).

Kaff, Samuel, kočijaš iz Iloka, rođen 1. 6. 1910. u Iloku, roditelji: Salamon Kaff i Matilda r. Weisz. Umro 18. 9. 1942. (31626/1942).

Kaff, Šandor, krojač iz Iloka, rođen 12. 8. 1894. u Iloku, roditelji: Jacob Kaff i Fanny r. Polak, supruga: Resa r. Stern. Umro 17. 9. 1942. (31196/1942)

Knöpfler, Marko, poljoprivrednik iz Iloka, rođen 13. 11. 1899. u Tinnye, Mađarska, roditelji: Samuel Knopfler i Cecilia r. Kohn (oboje u Tinnye), supruga: Jola r. Spiegel. Umro 12. 10. 1942. (35501/1942).

Neuschloss, Josef, strojarski tehničar iz Iloka, rođen 3. 6. 1903. u Paki (Paks) kod Tolne, Mađarska, roditelji: Emerich Neuschloss i Juliana r. Ausch, iz Pake, supruga: Margit Neuschloss r. Unger. Umro 16. 9. 1942. (31458/1942).

Perl, Lipot, namještenik iz Iloka, rođen 1. 10. 1904. u Papi kod Veszprema, Mađarska, roditelji: Mayer Perl i Irma r. Tauszig (Papa), supruga: Juliška r. Sztern. Umro 26. 9. 1942. (32935/1942).

Rosmann, Bernat, poljoprivrednik iz Iloka, rođen 3. 5. 1913. u Vizközu, Mađarska, roditelji: Farkas Rosmann i Anne r. Kratz (Hustz), supruga: Mawina r. Weiss. Umro 5. 10. 1942. (34588/1942).

Schwalb, Erna, pletilja iz Iloka, rođena 4. 4. 1922. u Mielecu kod Krakova, roditelji: Baruch (Abraham) Schwalb i Hilda r. Birnbaum. Umrla 24. 9. 1942. (32764/1942).

Silber, Aron, knjigoveža iz Iloka, rođen 5. 4. 1906. u Josikatelepu kod Bánffyhunyada, Mađarska, roditelji: Samuel Silber i Regina r. Rosenweg (Petrics, Mađarska), supruga: Rahela r. Schweid. Umro 18. 9. 1942. (31629/1942).

226 Postoji Falva, ali ne i Stojkofalva. 
Steiner, Marko, poljoprivrednik iz Iloka, rođen 12. 3. 1919. u Iloku, roditelji: Josip Steiner i Gita r. Lichtenstein, supruga: Rachel r. Prager. Umro 30. 9. 1942. (33740/1942).

Stern, Hana, prodavačica iz Iloka, rođena 14. 2. 1924. u Iloku, roditelji: Moische Stern i Regina r. Eckstein. Umrla 14. 9. 1942. (30563/1942).

Stern, Johanna, bez zanimanja, iz Iloka, rođena 11. 11. 1922. u Iloku, roditelji: Izrael Stern i Charlotte r. Laufer. Umrla 9. 10. 1942. (34926/1942).

Stern, Lazar, radnik iz Iloka, rođen 4. 2. 1911. u Iloku, roditelji: Moses Stern i Regina r. Eckstein, supruga: Frieda r. Winkler. Umro 1. 9. 1942. (26709/1942).

Stern, Lazar, trgovac iz Iloka, rođen 15. 6. 1899. u Iloku, roditelji: Sandor Stern i Esti r. Pollak, supruga: Melli r. Schrötter. Umro 28. 10. 1942. (37806/1942).

Stern, Lazar, radnik iz Iloka, rođen 8. 12. 1899. u Iloku, roditelji: Albert Stern i Berta r. Spiegel, supruga: Zlata r. Schlesinger. Umro 26. 9. 1942. (32933/1942).

Stern, Martha, iz Iloka, rođena 3. 2. 1915. u Beču, roditelji: Rudolf Kohn i Therese r. Deutsch, suprug: Leopold Stern. Umrla 17. 9. 1942. (31317/1942).

Stern, Moric, radnik iz Iloka, rođen 28. 5. 1908. u Iloku, roditelji: Albert Stern i Berta r. Spiegel, supruga: Mira r. Lipkowitsch. Umro 24. 9. 1942. (32508/1942).

Stern, Natan, namještenik iz Iloka, rođen 10. 3. 1921. u Iloku, roditelji: Mojse Stern i Regina r. Ekstein. Umro 16. 9. 1942. (31003/1942).

Stern, Rezinka, krojačica iz Iloka, rođena 3. 8. 1914. u Iloku, roditelji: Adolf Stern i Leonora r. Kaff. Umrla 28. 9. 1942. (33460/1942).

Wales, Relly, glačarica iz Iloka, rođena 9. 1. 1925. u Iloku, roditelji: Jakob Wales i Elsa r. Stern. Umrla 23. 9. 1942. (32415/1942).

Weber, Josef, poljoprivrednik iz Iloka, rođen 7. 1. 1922. u Iloku, roditelji: Szmul Weber i Fanny r. Goldenberg. Umro 17. 9. 1942. (31135/1942).

Weiss, Josef, radnik iz Iloka, rođen 21. 6. 1924. u Iloku, roditelji: Emanuel Weiss i Hanna r. Steinmetz. Umro 15. 9. 1942. (30791/1941).

\section{Ruma}

Almoslino, Ervin, precizni mehaničar iz Rume, rođen 1. 11. 1897. u Beču, roditelji: Sigmund Almoslino i Bertha r. Rosenfeld (Beč). Umro 22. 9. 1942. (32202/1942).

Ferstner, Aleksander, tapetarski naučnik iz Rume, rođen 20. 12. 1922., roditelji: Michal Ferstner i Paulina r. Keller. Umro 22. 10. 1942. (37075/1942).

Hacker, Rudolf, pekar iz Rume, rođen 14. 11. 1886. u Budimpešti, roditelji: Abraham Hacker i Fani r. Hacker, supruga: Rosa r. Bohenski. Umro 12. 9. 1942. (28015/1942). 
Hellinger, Bernhard, vodoinstalater iz Rume, rođen 21. 3. 1925. u Rumi, roditelji: Simon Hellinger i Margit r. Rosenbaum. Umro 18. 9. 1942. (31383/1942).

Hellinger, Simon, vodoinstalater iz Rume, rođen 1. 8. 1895. u Rumi, roditelji: Saul Hellinger i Terezia r. Kranz, supruga: Margita r. Rosenbaum. Umro 14. 9. 1942. (30573/1942).

Kaufman, Leo, trgovac iz Rume, rođen 26. 7. 1895. u Drenju, roditelji: Julius Kaufman i Ernestina r. Kraus (Ruma), supruga: Zlata r. Silberberg. Umro 15. 9. 1942. (29402/1942).

Krausz, Alexander, strojobravar iz Rume, rođen 22. 3. 1887. u Mohacsu, Mađarska, roditelji: Krausz Filip i Sofie r. Wachsler (Beč), supruga: Gabriele r. Mandel. Umro 26. 9. 1942. (32941/1942).

Löwenstein, Ludwig, trgovac iz Rume, rođen 19. 8. 1912. u Nürnbergu, roditelji: Wilhelm Löwenstein i Gizela r. Fraenkel (Zweibrücken, JZ Njemačka), supruga: Ruth r. Strauss. Umro 30. 9. 1942. (33773/1942).

Löwy, Irma, iz Rume, rođena 26. 4. 1900. u Schönkirchenu, roditelji: Josef Pulgram (Schönkirchen) i Katharina r. Fessler (Beč), suprug: Heinrich Löwy. Umrla 7. 9. 1942. (28705/1942).

Miller, Benjamin, radnik iz Rume, rođen 20. 1. 1904. u Polanki, Mađarska, roditelji: Sigmund Miller i Julienne r. Kohn, supruga: Mirjam r. Flesch. Umro 19. 10. 1942. (36765/1942).

Polacek, Rudolf, ${ }^{227}$ namještenik iz Rume, rođen 22. 1. 1914. u Rumi, roditelji: Samuel Polacek i Olga r. Weltmann. Umro 2. 10. 1942. (34077/1942).

Schönfeld, Willi, namještenik iz Rume, rođen 14. 12. 1907. u Požegi, Hrvatska, roditelji: Ernst Schönfeld i Berta r. Schlesinger, supruga: Olga r. Flesch. Umro 12. 9. 1942. (29392/1942).

Stein, Georg, elektromehaničarski naučnik iz Rume, rođen 21. 11. 1920. u Rumi, roditelji: Bernhard Stein i Luisa r. Berger. Umro 9. 10. 1942. (34776/1942).

Stein, Iren, pletilja iz Rume, rođena 9. 1. 1913. u Rumi, roditelji: Bernhard Stein i Luise r. Berger. Umrla 30. 9. 1942. (33665/1942).

Unterberger, Martin, tiskar iz Rume, rođen 31. 12. 1899. u Budimpešti, roditelji: Josef Unterberger i Sali r. Perlus, supruga: Janka r. Barkan. Umro 22. 9. 1942. (32245/1942).

Srijemska (tada: Hrvatska) Mitrovica

Förstner, Vilim, tvornički radnik iz Mitrovice, rođen 25. 12. 1900. u Mitrovici, roditelji: Samuel Förstner i Ethel r. Block. Umro 9. 10. 1942. (34777/1942).

Gärtner, David, ljekarnik iz Mitrovice, rođen 2. 9. 1909. u Opaki pokraj Lubaczowa (Ukrajina), roditelji: Herman Gärtner i Fany r. Gerstenfeld (Mitrovica). Umro 20. 9. 1942. (30240/1942).

227 Polaček. 
Klein, Stefan, namještenik iz Mitrovice, rođen 15. 10. 1909. u Čepinu, roditelji: Jozef Klein i Helena r. Seinner. Umro 14. 9. 1942. (30779/1942).

Morgernstern, Sandor, radnik iz Mitrovice, rođen 14. 4. 1901. u Cerni, roditelji: Adolf Morgernstern i Minna r. Klopfer, supruga: Jolanda r. Bergl. Umro 9. 10. 1942. (35083/1942).

Rosenberg, Maks, namještenik iz Mitrovice, rođen 8. 4. 1910. u Grgurevcima, roditelji: Rosenberg Adolf i Charlotta r. Gross. Umro 15. 9. 1942. (30643/1942).

Weitzenfeld, Eugen, liječnik iz Grgurevaca kod Mitrovice, rođen 20. 5. 1896. u Novom Sadu, roditelji: Bernard Weitzenfeld i Tereza r. Hofmann (Novi Sad), supruga: Rozina r. Fischer. Umro 4. 9. 1942. (27844/1942).

\section{Šid}

Blatt, Max, poljoprivrednik iz Šida, rođen 1. 3. 1904. u Bugojnu, roditelji: Markus Blatt i Ettina (Sarajevo), supruga: Gizela r. Schrottmann. Umro 30. 9. 1942. (33777/1942).

Francos, Jakob, poljoprivrednik iz Šida, rođen 3. 2. 1900. u Erdeviku, roditelji: Efraim Francos i Fanny r. Stern (iz Iloka), supruga: Gisela r. Stern (?!). Umro 23. 9. 1942. (32430/1942).

Hecht, Samuel, poljoprivrednik iz Šida, rođen 4. 9. 1908. u Vukovaru, roditelji: Herman Hecht i Johanna r. Engel (Vukovar), supruga: Charlotte r. Schrottmann. Umro 5. 10. 1942. (34259/1942).

Morgernstern, Filip, poljoprivrednik iz Šida, rođen 2. 10. 1897. u Čalmi pokraj Srijemske Mitrovice, roditelji: Adolf Morgernstern i Minna r. Klopfer, supruga: Lenka r. Morgernstern (?, op.a.). Umro 1. 10. 1942. (33860/1942).

Schrottmann, Josef, radnik iz Šida, rođen 15. 7. 1908. u Šidu, roditelji: Šandor Schrottmann i Etel r. Schlesinger, supruga: Rosa r. Reich. Umro 23. 9. 1942. (32467/1942).

Zilzer, Nandor, ${ }^{228}$ špediter iz Šida, rođen 25. 2. 1911. u Borocu (Barcs?, op. a.), Mađarska, roditelji: Benjamin Zilzer i Katica , r. Neiser (Bačka Palanka), supruga: Lotte r. Steinlauf. Umro 12. 10. 1942. (35790/1942).

\section{Vukovar}

Angelus, Zora, poljoprivrednica iz Vukovara, rođena 29. 3. 1921. u Vukovaru, roditelji: Julio Angelus i Elsa r. Polacek. Umrla 25. 9. 1942. (32705/1942).

Avramović, Olga, krojačica iz Vukovara, rođena 26. 7. 1922. u Vukovaru, roditelji: Abraham Avramović (Beograd) i Anuška r. Adut (Vukovar). Umrla 19. 9. 1942. (31865/1942).

\footnotetext{
${ }^{228}$ U izvorniku piše: Cilzer (netočno).
} 
Baum, Anna, iz Opatovca, rođena 7. 1. 1920. u Zagrebu, roditelji: Lav Mirski i Ilke r. Weingruber iz Vinkovaca, suprug: Karl Baum. Umrla 19. 9. 1942. (31678/1942).

Baum, Karl, poljoprivrednik iz Opatovca, rođen 15. 9. 1917. u Vukovaru, roditelji: Hugo Baum i Marta r. Rosamm (Tuzla), supruga: Anna Baum r. Fritz. Umro 25. 9. 1942. (32685/1942).

Klein, Liza, zubna tehničarka iz Vukovara, rođena 13. 10. 1922. u Vukovaru, roditelji: Daniel Klein i Lilly r. Pretzelmayer. Umrla 9. 9. 1942. (27901/1942).

Kohn, Gustav, staklar iz Vukovara, rođen 5. 3. 1904. u Vladislavcima, roditelji: Alexander Kohn i Josephine r. Lion, supruga: Regina r. Kolb. Umro 1. 10. 1942. (33849/1942).

Nemes, Ladislav, automehaničar iz Vukovara, rođen 2. 8. 1915. u Mađarskoj (O Morovica, ? op.a.), ${ }^{229}$ roditelji: Šandor i Elizabeth Nemes. Umro 29. 9. 1942. (33348/1942).

Polak, Zdenko, veterinar iz Vukovara, rođen 6. 2. 1921. u Vukovaru, roditelji: Ludwig Polak i Gizela r. Singer. Umro 15. 9. 1942. (30723/1942).

Rosendorn, Adolf, vrtlar iz Vukovara, rođen 31. 7. 1921. u Vukovaru, roditelji: Leopold Rosendorn i Franciska r. Polak. Umro 17. 9. 1942. (31203/1942).

Rosendorn, Filip, krojač iz Vukovara, rođen 22. 9. 1909. u Vukovaru, roditelji: Leopold Rosendorn i Franciska r. Polak. Umro 17. 9. 1942. (31089/1942).

Rosenfeld, Renka, rkt., namještenica iz Vukovara, rođena 31. 12. 1919. u Vukovaru, roditelji: Ladislav Rosenfeld (Zagreb) i Marta r. Frisch. Umrla 27. 9. 1942. (33270/1942).

Schnitzler, Greta, rkt., namještenica iz Vukovara, rođena 5. 5. 1917. u Zagrebu, roditelji: Vilem Schnitzler i Johanna r. Grünvald. Umrla 27. 9. 1942. (33525/1942).

Schön, Leo, liječnik iz Vukovara, rođen 26. 6. 1900. u Osijeku, roditelji: Hugo Schön i Julienna r. Sztrauss (Osijek), supruga: Olga r. Varjas. Umro 1. 10. 1942. (33912/1942).

Steiner, Ernst, službenik iz Vukovara, rođen 9. 7. 1901. u Makowu pokraj Krakova, roditelji: Adolf Steiner i Katerina r. Urbach (Zilin). Umro 13. 9. 1942. (30217/1942).

Steiner, Milan, zidarski naučnik iz Vukovara, rođen 29. 9. 1925. u Vukovaru, roditelji: Aleksandar Steiner i Ili r. Miskolzy. Umro 10. 10. 1942. (35264/1942).

Stern, Sandor, radnik iz Vukovara, rođen 27. 9. 1910. u Vukovaru, roditelji: Isidore Stern i Malvina r. Singer. Umro 20. 9. 1942. (30977/1942).

Stern, Slavko, radnik iz Vukovara, rođen 27. 9. 1914. u Vukovaru, roditelji: Isidor Stern i Malvine r. Singer. Umro 1. 10. 1942. (33984/1942).

229 Mjesto ovoga naziva nije zabilježeno na zemljopisnim kartama. 
Urman, Hinko, knjigoveža iz Vukovara, rođen 6. 6. 1916. u Stanislawowu, Poljska, roditelji: Draboutin Urman i Bertha r. Wilbert, supruga: Nancy r. Hofman. Umro 26. 10. 1942. (37521/1942).

\section{Županja}

Gros, Ivan, komercijalist iz Drenovaca, rođen 19. 5. 1898. u Nijemcima, roditelji: Simon Gros i Cecilia r. Hahn. Umro 16. 9. 1942. (30948/1942).

Grün, Vilim, trgovac iz Vrbanje, rođen 22. 7. 1901. u Vrbanji, roditelji: Gabo Grün i Malvina r. Rosenberg. Umro 21. 9. 1942. (32133/1942).

Kohn, Elemir, poljoprivrednik iz Štitara, rođen 18. 1. 1923. u Županji, roditelji: Aladar Kohn i Gizela r. Lichtenthal. Umro 3. 10. 1942. (34419/1942).

Kohn, Sigmund, rkt., trgovac iz Županje, rođen 12. 3. 1897. u Đakovu, roditelji: Adolf Kohn i Anna r. Boskovic, supruga: Eva r. Schmalz. Umro 7. 10. 1942. (34862/1942).

Pollak, Dragica, bez zanimanja, iz Slavonskog Šamca, rođena 4. 12. 1921. u Slavonskom Šamcu, roditelji: Josef Pollak i Paula r. Herzl. Umrla 18. 9. 1942. (31673/1942).

Pollak, Erich, elektrotehničar iz Slavonskog Šamca, rođen 30. 10. 1916. u Slavonskom Šamcu, roditelji: Josip Pollak i Paula r. Herzl. Umro 13. 9. 1942. (30345/1942).

Stark, Đuro, poljoprivrednik iz Rajeva Sela, rođen 22. 10. 1893. u Rajevu Selu, roditelji: Ignatz Stark (Rajevo Selo) i Rosalia r. Neuman (Novi Sad/Ujvidek). Umro 16. 9. 1942. (30952/1942). 


\section{Arhivski i neobjavljeni izvori}

DM AB: Državni muzej Auschwitz-Birkenau, Oświęcim, Poljska.

HR-HDA: Hrvatska, Hrvatski državni arhiv, Zagreb:

- fond 223-MUP NDH: Ministarstvo unutarnjih poslova Nezavisne Države Hrvatske.

- $\quad$ fond 252-RUR ŽO: Ravnateljstvo ustaškog redarstva, Židovski odsjek.

- fond 306-ZKRZ: Zemaljska komisija za utvrđivanje zločina okupatora i njihovih pomagača.

- fond 421-JTH SRH: Javno tužilaštvo Socijalističke Republike Hrvatske.

- fond 1076-PONOVA: Ministarstvo državne riznice, Odjel za novčarstvo, državnu imovinu i dugove, Ured za podržavljeni imetak.

- fond 1514-UPK NDH: Ustaško povjereništvo za grad i kotar Koprivnicu.

- fond 1521, Arhiv Hansa Helma.

- fond 1549-ZIG: Zbirka zapisa upravnih i vojnih vlasti Nezavisne Države Hrvatske i Narodnooslobodilačkog pokreta.

- fond 1561-SDS RSUP SRH: Služba državne sigurnosti Republičkog sekretarijata za unutrašnje poslove Socijalističke Republike Hrvatske.

JIM: Jevrejski istorijski muzej, Beograd, Židovske općine Zagreb, Ilok, Vinkovci, Zemun.

Muzej Vojvodine, Novi Sad, Kartoteka žrtava Drugog svjetskog rata na području Vojvodine.

RS 002-183-PKRZ: Srbija, Arhiv Vojvodine, Novi Sad, fond 183, Komisija za utvrđivanje zločina okupatora i njihovih pomagača u Vojvodini.

SR-AJ-50, Predsedništvo Vlade: Srbija, Arhiv Jugoslavije, Beograd, fond 50, Predsedništvo Vlade FNRJ.

SR-AJ-110-DKRZ: Srbija, Arhiv Jugoslavije, Beograd, fond 110, Državna komisija za utvrđivanje zločina okupatora i njihovih pomagača.

Židovska općina Zagreb, Popis žrtava lišenih života.

\section{Objavljeni izvori i tisak}

BABIĆ, Dušan. Zločini ustaša. Novi Sad: Polet pres, 2003.

CZECH, Danuta. „A Calendar of the Most Important Events in the History of the Auschwitz Concentration Camp". U: Auschwitz V: Epilogue. Auschwitz-Birkenau State Museum, 2000, 119-231.

CZECH, Danuta. Auschwitz Chronicle 1939-1945. New York: Henry Hold and Company, 1997.

ĆOSIĆ-BUKVIN, Ivica. „Vrbanjci stradalnici Drugog svjetskog rata”. Hrašće: časopis za književnost, umjetnost, kulturu i povijest 2 (1996): 31-37. 
Definitivni rezultati popisa stanovništva od 31 marta 1931 godine. Beograd: Državna štamparija, 1938.

Jasenovac: žrtve rata prema podacima Statističkog zavoda Jugoslavije. Reprint pripremili Meho Visočak i Bejdo Sobica. Zürich; Sarajevo: Bošnjački institut, 1998.

KLARSFELD, Serge. Le calendrier de la persécution des Juifs de France 1940-1944. Paris: Fayard, 1993.

"Der Korherr-Bericht" (Die Endlösung der Europäischen Judenfrage). NS-Archiv, Dokumente zum Nationalsozialismus. Pristup ostvaren 9. 4. 2021. https://www.ns-archiv.de/verfolgung/korherr/korherr-kurz.php.

LANDIKUŠIĆ, Rafael. Priručnik o političkoj i sudbenoj podjeli Nezavisne Države Hrvatske. Zagreb: Vlastita naklada, 1942.

MILETIĆ, Antun. Koncentracioni logor Jasenovac, knj. 1. Beograd: Narodna knjiga; Spomen-područje Jasenovac, 1986.

MILLER, Erwin. Izabran za umiranje. Zagreb: Durieux, 2004.

Narodne novine (Zagreb), 16 (1941).

NJEGOVAN, Drago, prir. Zločini okupatora i njihovih pomagača protiv Jevreja u Vojvodini. Novi Sad: Prometej, 2011.

PIZZUTI, Anna. „Dalla Jugoslavia occupata: Ebrei profughi, rifugiati, internati (1941-1943)". Ebrei stranieri internati in Italia durante il periodo bellico. Pristup ostvaren 17. 3. 2021. http://www.annapizzuti.it/index.php.

„Poimenični popis žrtava KL Jasenovac 1941-1945.” Spomen-područje Jasenovac. Pristup ostvaren 19. 3. 2021. http://www.jusp-jasenovac.hr/Default. aspx?sid=7618.

„Popis žrtava rata 1941-1945.: Vojvodina”. Muzej genocida, Beograd. Pristup ostvaren 21. 12. 2020. https://www.muzejgenocida.rs/2/popis-zrtava-rata-1941-1945.

„Popis žrtava rata 1941-1945.: SR Hrvatska”. Muzej genocida, Beograd. Pristup ostvaren 21. 12. 2020. https://www.muzejgenocida.rs/2/popis-zrtava-rata-1941-1945.

VELZEK, Hrvoje. Popis imena mjesta u Nezavisnoj Državi Hrvatskoj. Zagreb: Tipografija d.d., 1942.

ŽIVKOVIĆ, Dragoljub. Imenik stradalih osoba AP Vojvodine 1941. - 1948. Srem, tom III. Novi Sad: Skupština AP Vojvodine, 2009.

\section{Literatura}

BETHKE, Carl. (K)eine gemeinsame Sprache?: Aspekte deutsch-jüdischer Beziehungsgeschichte in Slawonien, 1900-1945. Berlin: LIT, 2013.

BUĆIN, Rajka. „Prilog poznavanju institucija: zakonski okvir rada velikih župa”. Arhivski vjesnik 44 (2001): 209-225.

DĘBSKY, Jerzy; GOLDMANN, Sybile; JASTRZĘBSKA, Halina; KREUZHAGE, Stephanie; PARCER, Jan, ur. Death Books from Auschwitz (Ster- 
bebücher von Auschwitz), vol. 1: Reports. München; New Providence; London; Paris: K. G. Saur, 1995.

DIZDAR, Zdravko. Logor Danica u Koprivnici 1941. - 1942., knj. 1. Koprivnica: Muzej grada, 2017.

DIZDAR, Zdravko. „Logori na području sjeverozapadne Hrvatske u toku drugoga svjetskog rata 1941. - 1945. godine”. Časopis za suvremenu povijest 22 (1990), br. 1-2: 83-110.

DOBROVŠAK, Ljiljana. Židovi u Srijemu: od doseljenja do Holokausta. Vukovar: Gradski muzej, 2017.

ERAK, Petar. „Rumski Jevreji u Drugom svetskom ratu”. Portal Radio Gornji grad, 30. 4. 2014. Pristup ostvaren 18. 11. 2020. http://radiogornjigrad. wordpress.com/2014/04/30/petar-erak-rumski-jevreji-u-drugom-svetskom-ratu/.

FOGEL, Danilo. Jevrejska zajednica u Zemunu. Hronika (1739. - 1945.). Zemun: Jevrejska opština, 2002.

„Franz Abromeit”. Wikipedia. Pristup ostvaren 17. 3. 2021. https://en.wikipedia.org/wiki/Franz_Abromeit.

GOLDSTEIN, Ivo. „Solidarnost i pomoć Židovima u Hrvatskoj”. Radovi Zavoda za hrvatsku povijest Filozofskoga fakulteta Sveučilišta u Zagrebu 34-36 (2004): 205-228.

GOLDSTEIN, Ivo; [GOLDSTEIN, Slavko (suautor)]. Holokaust u Zagrebu. Zagreb: Novi liber, 2001.

GRUENFELDER, Anna Maria. „Nepoželjni gosti. Židovske izbjeglice u Jugoslaviji (1938-1945)”. Zbornik JIM 10 (2015): 303-362.

GRUENFELDER, Anna Maria. Sustigla ih Šoa. Strani židovski izbjeglice u Jugoslaviji (1933. - 1945.). Zagreb: Srednja Europa, 2018.

HEĐBELI, Živana. „Ponova”. Novi omanut: prilog židovskoj povijesti i kulturi 47-48 (2001): 5-7.

KEVO, Mario. „Počeci jasenovačkog logora i pojmovna (terminološka) problematika Sustava jasenovačkih logora”. U: Dijalog povjesničara - istoričara 9, prir. Hans-Georg Fleck i Igor Graovac. Zagreb: Zaklada Friedrich Naumann, 2005, 573-589.

KEVO, Mario. „Počeci logora Jasenovac”. Scrinia Slavonica 3 (2003): 471-499.

KOLJANIN, Milan. „Jevreji žrtve rata 1941.-1945. godine u Vojvodini”. $\mathrm{U}$ : Zbornik radova sa naučnog skupa „Istina o događanjima u AP Vojvodini u periodu 1941-1945”, ur. Dragoljub Živković. Novi Sad: Skupština APV, 2004, 167-202.

KOLJANIN, Milan. Nemački logor na beogradskom Sajmištu 1941-1945. Beograd: Institut za savremenu istoriju, 1992.

KOVAČIĆ, Davor. Redarstveno-obavještajni sustav Nezavisne Države Hrvatske od 1941. do 1945. godine. Zagreb: Hrvatski institut za povijest, 2009. 
KRIZMAN, Bogdan. Ustaše i Treći Reich, sv. 1. Zagreb: Globus, 1983.

KUMOVIĆ, Mladenko. Stradanje sremskih Jevreja u holokaustu. Novi Sad: Muzej Vojvodine, 2007.

LEBL, Ženi. „'Kindertransport' iz Nezavisne Države Hrvatske februara 1943." Zbornik JIM 9 (2009): 185-352.

LENGEL-KRIZMAN, Narcisa. „Koncentracioni logori talijanskog okupatora u Dalmaciji i Hrvatskom primorju (1941-1943)". Povijesni prilozi 2 (1983), br. 1: 247-283.

LENGEL-KRIZMAN, Narcisa. „Kronologija židovskog stradanja 1938.1945." U: Antisemitizam, holokaust, antifašizam, redakcija Ivo Goldstein et al. Zagreb: Židovska općina, 1996, 247-256.

LENGEL-KRIZMAN. „Logori za Židove u NDH.” U: Antisemitizam, holokaust, antifašizam, redakcija Ivo Goldstein et al. Zagreb: Židovska općina, 1996, 91-103.

LENGEL-KRIZMAN, Narcisa. „Prilog proučavanju terora u tzv. NDH: Ženski sabirni logori 1941. - 1942. godine”. Povijesni prilozi 38 (1985), br. 1: $1-38$.

MOTL, Dejan; MIHOVILOVIĆ, Đorđe. Zaboravljeni. Knjiga o posljednjim jasenovačkim logorašima. Jasenovac: Javna ustanova Spomen-područje Jasenovac, 2015.

PERŠEN, Mirko. Ustaški logori. Zagreb: Stvarnost, 1966.

PINTO, Samuel. Zločini okupatora i njihovih pomagača izvršeni nad Jevrejima u Bosni i Hercegovini (elaborat Zemaljske komisije za BiH). Sarajevo, 1952 [rukopis].

PIPER, Francizsek. „Introduction”. U: Auschwitz I: The Establishment and Organization of the Camp. Oswiecim: Auschwitz-Birkenau State Museum, 2000, 15-37.

PIPER, Franciszek. „The Role of the Auschwitz Camp in the Nazi Policy of Enslavement and Mass Murder". U: Auschwitz III: Central Issues in the History of the Camp: Mass Murder. Oswieçim: Auschwitz-Birkenau State Museum, 2000, 9-61.

PIPER, Franciszek. „The Methods of Mass Murder”. U: Auschwitz III: Central Issues in the History of the Camp: Mass Murder. Oswieçim: Auschwitz-Birkenau State Museum, 2000, 63-204.

PUŠKAR, Slavko; KORDA, Josip. Vinkovački kraj na putu u slobodu i socijalizam. Vinkovci: Skupština općine OK SKH; SUBNOR Vinkovci, 1976.

RAKIČIĆ FRIEDRICH, Zdenka. Razvoj željezničke mreže u hrvatskom Podunavlju 1850. - 1914. Vukovar: Gradski muzej, 2006.

RISTOVIĆ, Marko. U potrazi za utočištem. Jugoslovenski Jevreji u bekstvu od holokausta 1941-1945. Beograd: Službeni list SRJ, 1998.

ROMANO, Jaša. Jevreji Jugoslavije 1941-1945. Žrtve genocida i učesnici Narodno oslobodilačkog rata. Beograd: Savez jevrejskih opština Jugoslavije, 1980. 
SREMAC, Radovan; KLEIN, Emil. Jevreji u Šidu. Šid: Narodna biblioteka „Simeon Piščević”, 2014.

STUPARIĆ, Darko, gl. ur. Tko je tko u NDH. Hrvatska 1941. - 1945. Zagreb: Minerva, 1997.

ŠALIĆ, Tomo. Židovi u Vinkovcima i okolici. Osijek: Židovska općina, 2002.

ŠOSBERGER, Pavle. Jevreji u Vojvodini: kratak pregled istorije vojvođanskih Jevreja. Novi Sad: Prometej, 1998.

ŠTAMBUK-ŠKALIĆ, Marina. „Hrvatska istočna granica u dokumentima 1945-1947”. Fontes 1 (1995): 153-329.

ŠVOB, Melita. Židovi u Hrvatskoj. Židovske zajednice, knj. 2. Zagreb: Židovska općina, 2004.

TAUBER, Eli. Holokaust u Bosni i Hercegovini. Sarajevo: Institut za istraživanje zločina protiv čovječnosti i međunarodnog prava, 2014.

VASILJEVIĆ, Zoran. Sabirni logor Đakovo. Slavonski Brod: Centar za povijest Slavonije i Baranje; Spomen-područje Jasenovac, 1988.

VULETIĆ, Dušan. „Akcija Viktora Tomića i pokretni preki sud u Sremu”. U: Na putu ka istini, autori tekstova Ljubivoje Cerović et al. Novi Sad: Biblioteka Matice srpske, 2009, 122-157.

ZATEZALO, Đuro. Jadovno, knj. 1: Kompleks ustaških logora 1941. Beograd: Muzej žrtava genocida, 2007.

ŽIVAKOVIĆ-KERŽE, Zlata. Stradanja i pamćenja. Holokaust u Osijeku i život koji se nastavlja. Slavonski Brod: Hrvatski institut za povijest, Podružnica za povijest Slavonije, Srijema i Baranje, 2006.

ŽUGIĆ, Tomislav; MILIĆ, Miodrag. Jugosloveni u koncentracionom logoru Aušvic 1941-1945. Beograd: Institut za savremenu istoriju, 1989. 


\section{Transport Sent to Auschwitz from Vinkovci in August 1942 and the Fate of Syrmian Jews and Jews from Bijeljina during World War II}

In August 1942, five transports were sent to the concentration camp Auschwitz-Birkenau from the territory of the Independent State of Croatia (ISC), with approximately 5,000 Jews. One of them was sent from Vinkovci with circa 1,000 Jews. It left the territory of the ISC on 19 August, and arrived in Auschwitz on 22 August. The transport has been only partially researched, mostly regarding victims from the Serbian part of the Syrmia region, without taking into account the complete picture, and with various omissions and mistakes. Documents scattered in numerous archival and other heritage institutions, many of them unknown to research communities in Croatia and Serbia, compared with statistical data for inhabitants of the settlements included in the analysis, reveal what was going on with Jewish communities not only in the wider region of Syrmia (Srijem), nowadays in Croatia and Serbia, but also in Bijeljina in Bosnia and Herzegovina, from where Jews were also incorporated into that transport. The analysis includes not only Jews who were sent to Auschwitz via the detention camp in Vinkovci, where they were kept during July and August 1942 (Jews from Vukovar, Županja, Ruma, Sremska Mitrovica, Bijeljina, Ilok, Šid, maybe some from Stara Pazova), but also those who were sent to the concentration camps in Jasenovac and Stara Gradiška from May to August 1942 (Jews from Vinkovci and Zemun, most of the Jews from Stara Pazova, maybe/probably some of those from Ilok and Šid). The paper also includes a review of the destiny of Syrmian and Bijeljina's Jews during 1941 and in the earlier period of 1942. The Holocaust was almost complete in those areas in August 1942. The only exemption was granted to Jews in mixed marriages and their children, those employed in medical services, and individuals who were exempt on some other basis. Most of them perished in the next wave of deportations in May 1943. The results of the research give a clearer picture of the flow of Holocaust in that part of the territory of the ISC and can be used for the correction and supplementation of the data about victims, not only of the individuals who perished in Auschwitz, registered in the death books from the camp or confirmed as victims of that camp by other sources, but also of those who perished in the concentration camps Jasenovac and Stara Gradiška. Regarding the Croatian part of Syrmia, some new results refer to the victims from Vukovar and Ilok who perished in Auschwitz but were previously linked to the Jasenovac and Stara Gradiška camps. Some of the victims, e.g. those from Županja, were not registered at all, and were mostly deported to Auschwitz. The data for Jews from Vinkovci and Zemun, almost all of whom perished in Jasenovac and Stara Gradiška from May to July 1942, can also be updated from the transfer lists of the Ustasha Surveillance Service (Ustaška nadzorna Služba, UNS) used in this research.

Key words: Independent State of Croatia (ISC); Holocaust; Auschwitz; Jasenovac; detention camp in Vinkovci; Syrmia; Bijeljina 